\title{
MINISTERIO DE SALUD PÚBLICA
}

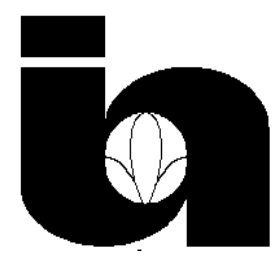

\section{INSTITUTO DE NUTRICIÓN E HIGIENE DE LOS ALIMENTOS}

FACULTAD DE CIENCIAS MÉDICAS "CALIXTO GARCÍA”

Caracterización del mejillón verde (Perna viridis) de la Bahía de Cienfuegos, como posible alimento para el consumo humano

Tesis Presentada en Opción al Título Académico de MÁSTER EN NUTRICIÓN EN SALUD PÚBLICA

Autor: Lic. Yeniset Fumero Acosta

Tutores: Dra.C. Adriana Artiles Valor

Ms.C. Roberto Castelo Báez

La Habana, 2013 
AGRADECIMIENTOS

Quisiera agradecer en este momento a todas las personas que hicieron posible no sólo este trabajo sino el sueño que parecía casi inalcanzable de obtener: el título de máster.

A mi hijo Flavio que desde que estaba en la panza tuvo que escuchar las conferencias de los profesores, sin entender ni una sola palabra y después soportar el sol del P1 de regreso a casa. Por portarse tan bien.

A mi esposo Jorge L. por aguantar todas mis majaderías y ayudarme a levantar el ánimo en los momentos más difíciles. Por estar siempre ahí cuando lo necesito.

Al resto de mi familia y en particular a mi hermana por la impresión.

A mis tutores Adriana y Castelo, por darme todo su apoyo y trasmitirme todas sus experiencias. Por todo el amor y el esfuerzo que le han dedicado a este proyecto.

A todos mis compañeros del Instituto de Nutrición e Higiene de los Alimentos. A los profesores de la maestría y a los organizadores: Arturo, Leandro y Abigalys. A Beatriz, Armando y al resto del Comité Académico por haberme concedido más tiempo. Y en especial a Ahindris y Carlos por hacerme levantar cuando pensaba que todo estaba perdido.

A todos mis compañeros del Centro de Investigaciones Pesqueras. A cada uno de los que puso su granito de arena en esta investigación, en especial a los técnicos que realizaron los análisis.

A Mayelin, Mayleé y Carmen por ayudarme a enderezar el texto. A M. Aurora, Yuliesky, Abelito, Yanara por darme su ayuda. A Raquel por aceptar que escogiera este tema.

A los compañeros de la Empresa Pesquera Industrial de Cienfuegos por el apoyo logístico.

A Arias Verdes y Luisa por su trabajo y colaboración.

A los colegas del CIMAB y del CEAC por ofrecernos valiosa información.

A todos

Muchas Gracias 
A Flavio y a Jorge 


\section{ÍNDICE}

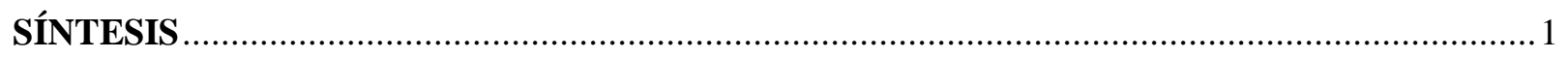

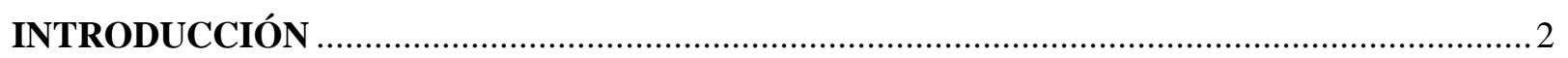

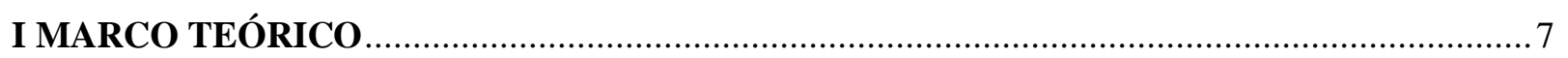

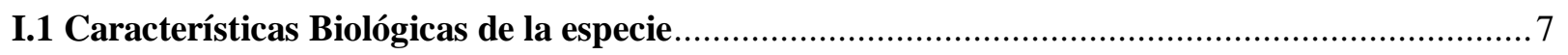

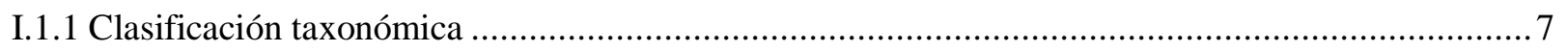

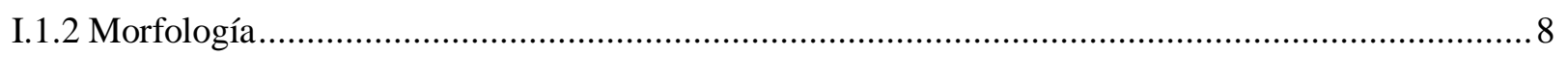

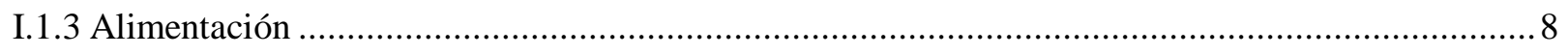

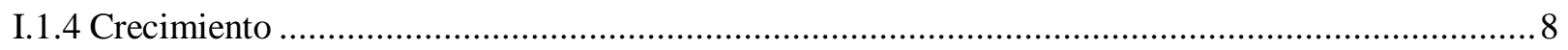

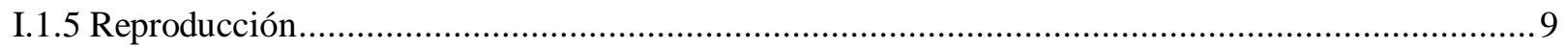

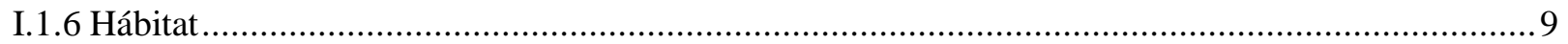

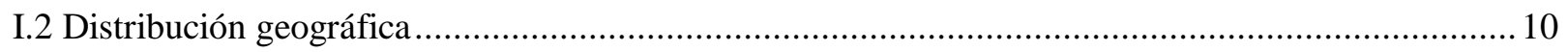

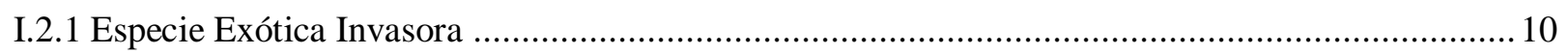

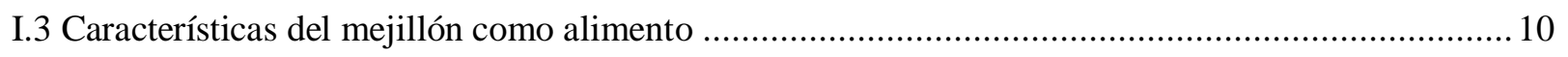

I.3.1 Capturas y Consumo del mejillón verde $P$. viridis ............................................................... 10

I.3.2 Formas de presentación y comercialización ..................................................................... 12

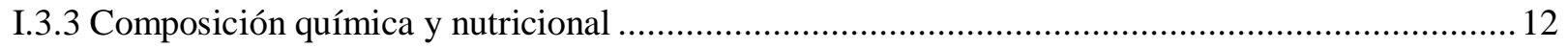

I.4 Factores que pueden afectar la inocuidad de los moluscos bivalvos ........................................ 14

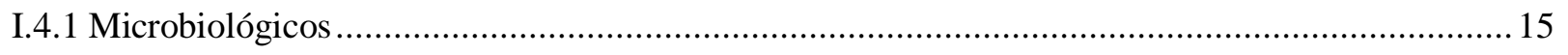

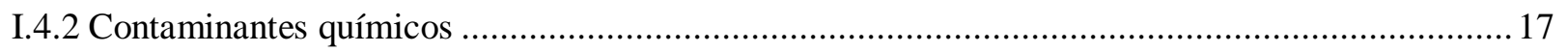

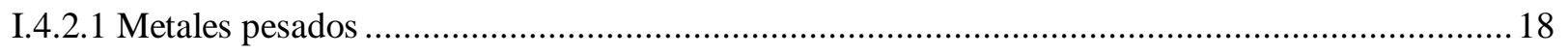

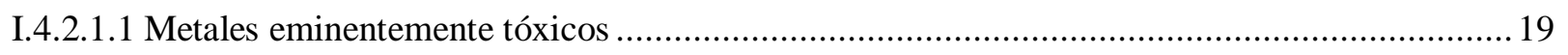

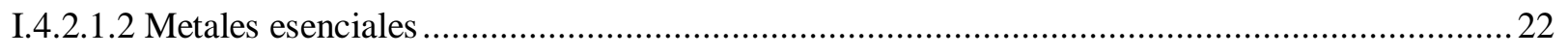

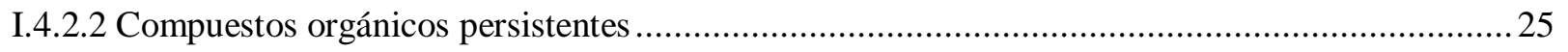

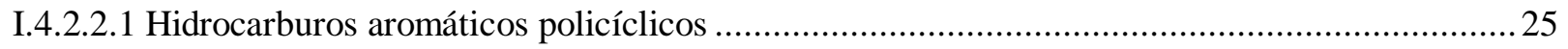

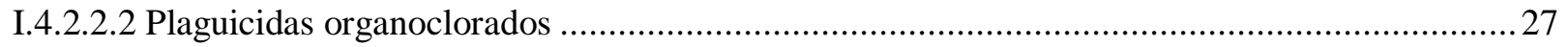

I.4.2.2.3 Dioxinas/Furanos, Policlorobifenilos similares a las Dioxinas y Policlorobifenilos indicadores

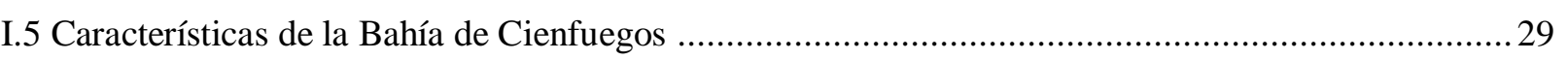

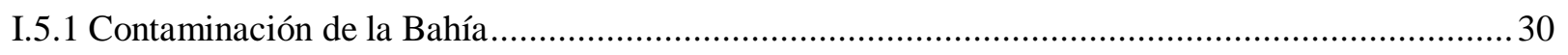

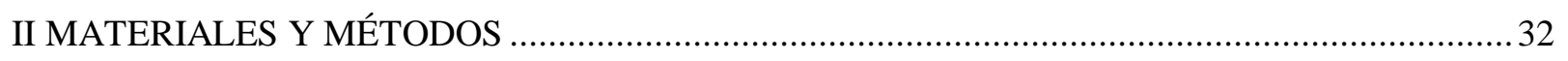

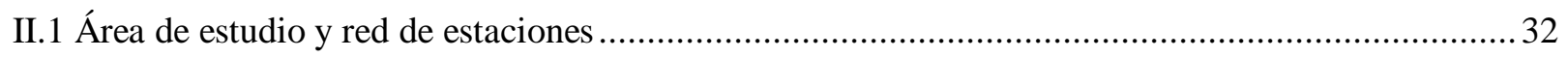

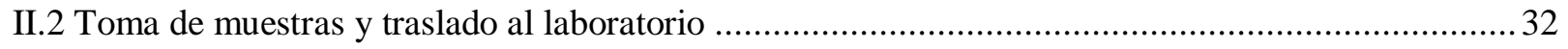




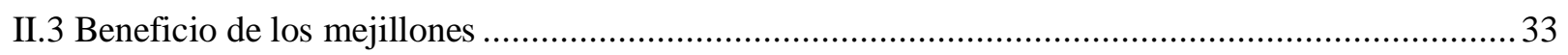

II.4 Determinación de la fracción comestible de la especie con talla comercial ..................................33

II.5 Estimación de la composición proximal del mejillón verde crudo y cocido....................................34

II.6 Análisis microbiológico del mejillón fresco ....................................................................... 36

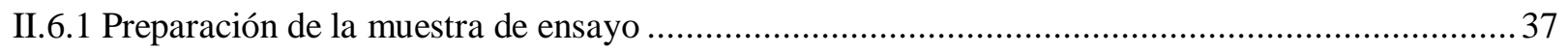

II.6.2 Preparación de la suspensión inicial y de las diluciones decimales adicionales .........................3 37

II.7 Evaluación de diferentes formas de procesamiento mediante la variación de los tiempos de cocción

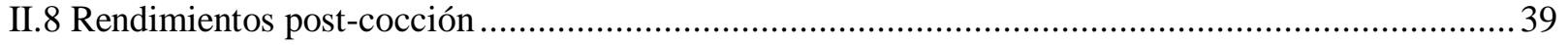

II.9 Determinación de metales pesados en la fracción comestible del mejillón verde............................40

II.10 Determinación de compuestos orgánicos persistentes en masa de mejillón verde ........................41

II.10.2 Determinación de Palguicidas Organoclorados, Policlorobifenilos (PCBs) indicadores, Dioxinas/Furanos y PCBs similares a Dioxinas ......................................................................... 42

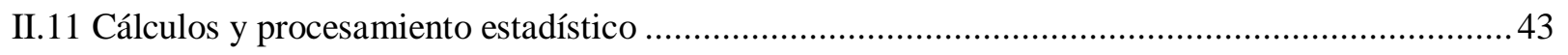

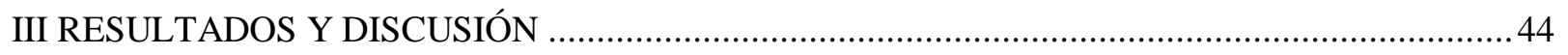

III.1 Fracción comestible de la especie para tallas comerciales .......................................................44

III.2 Composición proximal del mejillón verde crudo y cocido ...........................................................45

III.3 Calidad microbiológica del mejillón fresco .........................................................................4 47

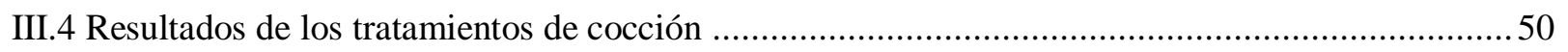

III.5 Metales pesados de la fracción comestible de mejillones con talla comercial..............................53

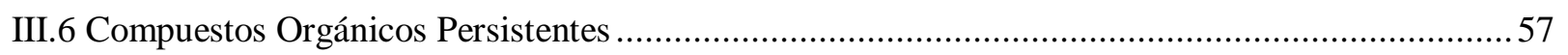

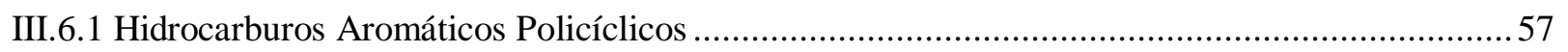

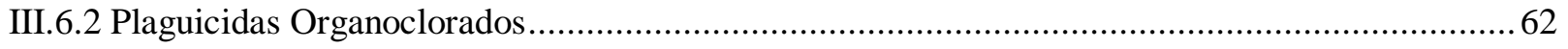

III.6.3 Dioxinas/Furanos, Policlorobifenilos similares y no similares a las Dioxinas ..........................64

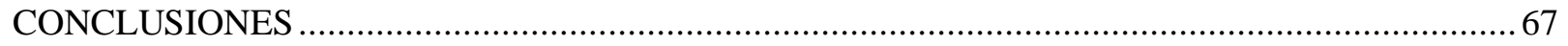

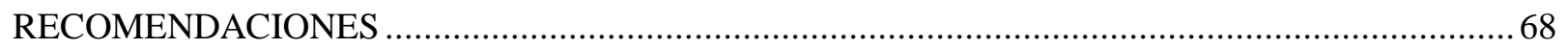

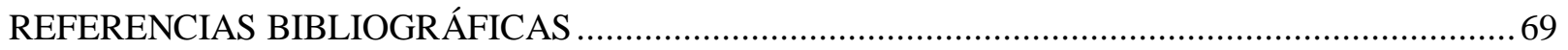




\section{SÍNTESIS}

El mejillón verde Perna viridis (Linnaeus, 1758) nativo del Indo Pacífico, fue reportado en Cuba por primera vez en el año 2005, en la Bahía de Cienfuegos. Una de las alternativas propuestas para reducir el impacto de esta especie invasora en nuestro territorio fue su evaluación con fines de extracción y comercialización. Por tal, el problema de nuestra investigación fue analizar si el mejillón verde de la bahía de Cienfuegos era un alimento inocuo para el hombre. Nos trazamos como objetivo principal la caracterización del mejillón verde (Perna viridis) de la Bahía de Cienfuegos como posible alimento para el consumo humano. Para abordar este tema, se realizó un análisis de la fracción comestible del molusco y de su composición proximal. Además se realizaron determinaciones de la calidad higiénico-sanitaria del mejillón fresco, el contenido de metales pesados y de compuestos orgánicos persistentes en la fracción comestible. También se evaluaron algunas formas de procesamiento teniendo en cuenta la carga microbiana y los rendimientos postcocción. Los principales resultados fueron, los mejillones verdes presentaron un rendimiento de la fracción comestible y un aporte en proteínas, lípidos y energía superior a otros moluscos bivalvos procesados en Cuba; sin embargo, mostraron contaminación con: Hidrocarburos, plaguicidas organoclorados, dioxinas y furanos y bifenilos policlorados similares a dioxinas. Por tanto, el mejillón verde de la Bahía de Cienfuegos aunque es un alimento de gran valor potencial para el mercado no puede consumirse a partir de las zonas de pesca estudiadas, pues no reúne los niveles de inocuidad necesarios. 


\section{INTRODUCCIÓN}

Desde la antigüedad son famosos algunos bivalvos comestibles, como los ostiones, las almejas y los mejillones. En los trópicos se pueden recolectar en forma natural y cultivar de manera relativamente barata, siendo esto una tradición para muchos países de Asia y el Pacífico, lo que proporciona una fuente fácil de alimentos (1). En América Latina y el Caribe, Chile es el mayor productor en la región y las principales especies que se producen son el mejillón chileno y la concha de abanico. En nuestro país los moluscos bivalvos más capturados son el ostión de mangle (Crassostrea rhizophorae), especie ampliamente estudiada y de tradicional consumo por los cubanos, y la almeja (Arca zebra) $(2,3)$.

El mejillón verde Perna viridis (Linnaeus, 1758) nativo del Indo Pacífico, constituye un recurso económico de interés y una importante fuente de proteínas para la población del sureste asiático (4), debido a sus altos rendimientos en comparación con cualquier otro bivalvo cultivado en esta región (5). Los mejillones son organismos filtradores, proceso mediante el cual se alimentan. Son capaces de filtrar entre 4 y 8 galones de agua por día. Esta forma de alimentación hace que los moluscos bivalvos como Perna viridis, presenten altos riesgos potenciales a la salud humana, lo cual estará en dependencia de la calidad ambiental de su hábitat (6). La acumulación de contaminantes en este bivalvo, puede ser tanto de microorganismos, virus, biotoxinas, metales pesados, hidrocarburos y otros compuestos orgánicos persistentes $(7,8)$. En muchos casos son utilizados como organismos centinelas de diversos tipos de contaminación, por los diferentes biomarcadores cuantificables, que se expresan ante una situación de estrés $(9,10,11,12)$. En términos generales son vehículos en la transmisión de toxiinfecciones alimentarias. La incidencia de estos brotes constituye uno de los problemas de salud pública más extendidos y ocupan el segundo lugar entre las enfermedades de notificación obligatoria. Se ha estimado que una de cada dos mil comidas de moluscos crudos origina enfermedades $(13,14,15)$. Además, su consumo habitual desde zonas contaminadas puede constituir un riesgo para la salud a largo plazo por la presencia de metales pesados, hidrocarburos aromáticos policíclicos (e.g. benzo(a)pireno), dioxinas, furanos, policlorobifenilos entre otros, que en su mayoría están catalogados como cancerígenos o posibles cancerígenos al hombre (16). 
El mejillón verde ( $P$. viridis) es reportado por primera vez en el año 2005, en la Bahía de Cienfuegos. Se estima que fue una introducción accidental, a través del agua de lastre de buques o adherido a sus cascos (17). Esta especie invasora, proliferó rápidamente hasta constituir un problema económico para la Central Termoeléctrica "Carlos Manuel de Céspedes", debido a la obstrucción de los canales de enfriamiento que obligaron a realizar paradas periódicas para efectuar su limpieza (18).

La erradicación total de una especie introducida y/o invasora, es el estado ideal frente a la mitigación o eliminación de impactos. Sin embargo, esto resulta muy difícil en los ambientes marinos, costeros o de aguas interiores; siendo una opción el manejo y control de la especie (19). Una de las alternativas propuestas para reducir el impacto de Perna viridis en nuestro territorio fue la evaluación de la especie con fines de explotación comercial. A finales del 2010, el Centro de Investigaciones Pesqueras creó un proyecto de investigación: Manejo de la especie invasora, Perna viridis (mejillón verde) de la Bahía de Cienfuegos a través de su explotación comercial. Ejecutado en el 2011 por un grupo de trabajo (del cual formó parte la autora de esta tesis), en colaboración con la Empresa Pesquera Industrial Cienfuegos (EPICIEN) (20).

Las principales líneas de investigación de este proyecto estuvieron direccionadas hacia: a) Caracterización hidrográfica e hidrodinámica de la Bahía; b) Evaluación de la abundancia, distribución y de la fauna acompañante de Perna viridis; c) Análisis de su ciclo reproductivo; d) Indicadores de su estado de salud; e) Caracterización del mejillón como alimento y f) Determinación de la contaminación química y microbiológica de su porción comestible.

El presente trabajo se centró en los dos últimos perfiles. Evalúa la factibilidad de considerar al mejillón verde de la bahía de Cienfuegos como un recurso pesquero comercial. Para abordar este tema, primero se realiza un análisis de los rendimientos de esta especie en diferentes formas de procesamiento y de su composición proximal. Además nos planteamos los principales riesgos para la salud, que puede representar el consumo de este bivalvo, debido a la calidad de las aguas donde se desarrolla, teniendo en cuenta su capacidad filtradora. Por lo cual se realizaron a la masa de este molusco determinaciones de calidad microbiológica, contenido de metales pesados y de compuestos orgánicos persistentes (COPs). 
Este tema de investigación tiene importancia, pues los resultados serán de utilidad para la toma de decisiones en relación al manejo adecuado de esta especie por parte de las autoridades competentes. Tiene la novedad de caracterizar a Perna viridis como alimento a partir de su actual hábitat, sirviendo como punto de partida para otras regiones del país donde pudiera aparecer. Los resultados tienen como impacto el estar encaminados al cuidado de la Salud Pública de un posible grupo poblacional consumidor de este molusco. Por tanto la utilidad fundamental de esta pesquisa es poner en alerta a las autoridades competentes para frenar el consumo sin previa certificación de este producto.

En tal sentido, nuestra investigación tiene como objeto el mejillón verde (P.vridis) de talla comercial como alimento para el consumo humano.

Se asume como problema de investigación, el cuestionamiento: ¿Es el mejillón verde ( $P$. viridis) de la bahía de Cienfuegos un alimento inocuo para el consumo humano?

Nuestra hipótesis consiste en que el mejillón verde ( $P$. viridis) de la bahía de Cienfuegos no cumple con los requisitos de inocuidad necesarios para ser un alimento libre de riesgo para el consumo humano, debido a que está distribuido en un ecosistema con un apreciable impacto antropogénico e industrial.

Para el establecimiento de las características biológicas de $P$. viridis, es fundamental el texto, Greening of the coasts: a review of the Perna viridis success story realizado por S. Rajagopal (21), donde elabora un resumen detallado de las investigaciones más relevantes realizadas sobre esta especie. En el caso de sus formas de producción y comercialización, son significativos los trabajos Estado actual del cultivo y manejo de moluscos bivalvos y su proyección futura: factores que afectan su sustentabilidad en América Latina y Cultivo de bivalvos en Asia y el Pacifico, de Alessandro Lovatelli y Rian Davy, respectivamente (1, 22), nos permiten conocer las principales formas de procesamiento y comercialización de este bivalvo y los rendimientos de este recurso pesquero en otras partes del mundo que sustentan la factibilidad de su explotación. Para comparar los valores de composición química y conocer el aporte nutricional de este alimento, utilizamos como guía fundamental Chemical and Nutritional Composition of Finfishes, Whales, Crustaceans, Mollusks and their Products de Sidwell (23) y la investigación de Ana M. Cabello, sobre los parámetros de frescura en 
moluscos, dentro de la cual analiza la composición bromatológica de Perna viridis (24). A la hora de constituir los indicadores de calidad que se tomarían en cuenta para considerar al mejillón verde un alimento inocuo, es de gran ayuda la norma Codex Stan 292-2008 para los moluscos bivalvos vivos y los moluscos bivalvos crudos, en la cual se refieren los límites máximos de contaminantes para estos productos (25). A partir de esta norma y en la medida de las posibilidades analíticas con que contamos, realizamos las determinaciones pertinentes, comparando los resultados en la mayoría de los casos con la normativa cubana y de la Comunidad Europea, por su rigurosidad y por ser el mercado más frecuente de los productos de la pesca cubanos.

Al mismo tiempo era primordial conocer el comportamiento del hábitat donde se emplazó este bivalvo, la Bahía de Cienfuegos, a través de sus características hidrodinámicas e hidroquímicas y los tipos y fuentes de contaminación que afectan este ecosistema. Para lo cual analizamos los reportes realizados por investigadores del Centro de Ingeniería y Manejo Ambiental de Bahías y Costas (CIMAB) específicamente a Liuba Chabalina y Jesús Beltrán (26) y a Alain Muñoz (27), Mabel Seisdedo (28, 29) y Carlos Manuel Alonso (30) del Centro de Estudios Ambientales de Cienfuegos (CEAC). Además son importantes los estudios realizados por el CEAC en colaboración con la Agencia Internacional de Energía Atómica de Mónaco, sobre la presencia de COPs en este acuatorio $(31,32)$. El trabajo sistematizado de estos dos centros nos da una perspectiva general de este sistema y de los contaminantes a que puede estar expuesto $P$. viridis. Igualmente partimos de los antecedentes del trabajo de Yuliesky Garcés y colaboradores, que relacionan las características hidrometeorológicas de este ecosistema con la presencia de $P$. viridis (33).

Para desarrollar esta investigación En cuanto a la distribución de los capítulos, en el primero se fundamenta teórica y metodológicamente esta investigación. Consta de un grupo de acápites relacionados entre sí, en el cual nos acercamos al mejillón verde (P.viridis), como organismo vivo, a través de sus características biológicas, su distribución geográfica y la declaración de este como especie exótica invasora. Además, mostramos esta especie como alimento, sus formas de presentación, comercialización, niveles de producción mundial y aporte nutricional al consumo humano. Por último, los principales factores que están relacionados con la alteración de su inocuidad y los posibles riesgos a la salud pública, como son: la contaminación 
microbiológica, metales pesados, hidrocarburos aromáticos policíclicos, pesticidas organoclorados, dioxinas, furanos y policlorobifenilos.

En el segundo capítulo se describe, la zona de muestreo los métodos y técnicas utilizadas para el análisis de los diferentes parámetros estudiados.

A la hora de establecer el aparato conceptual de nuestra investigación, tomamos en consideración la capacidad de operacionalización de estos, para el desarrollo lógico de nuestro trabajo. El término inocuidad de los alimentos hace referencia a:

"la propiedad de asegurar que los alimentos no vayan a causar daño al consumidor cuando este sea preparado y/o consumido de acuerdo con el uso que debería dársele" (34). Y a la vez, "hacen referencia a todos los riesgos, sean crónicos o agudos, que pueden hacer que los alimentos sean nocivos para la salud del consumidor" (35).

Otro término fundamental en nuestra investigación, la fracción comestible, que es la porción de los moluscos bivalvos constituida por todos los tejidos blandos que se encuentra protegidos entre las dos valvas, también considerada porción comestible. Este término ha sido elaborado y ampliado a partir de la conceptualización dada en la Norma para moluscos bivalvos (25).

Por tanto nuestro objetivo principal es, caracterizar el mejillón verde (Perna viridis) de la Bahía de Cienfuegos como alimento, para determinar su nivel de inocuidad. A la vez, nuestros objetivos específicos son:

- Estimar los rendimientos de la fracción comestible y la composición proximal del mejillón verde (P. viridis).

- Evaluar la calidad microbiológica del molusco fresco.

- Evaluar diferentes formas de procesamiento mediante la variación de los tiempos de cocción y el rendimiento obtenido.

- Analizar el nivel de contaminación con metales pesados de la fracción comestible.

- Determinar la presencia de compuestos orgánicos persistentes en la fracción comestible. 


\section{MARCO TEÓRICO}

\section{I.1 CARACTERÍSTICAS BIOLÓGICAS DE LA ESPECIE}

Los bivalvos constituyen la segunda clase más numerosa dentro del phylum Mollusca, con una radiación evolutiva estimada en unas 6.250 especies recientes. Su característica distintiva fundamental es tener el cuerpo protegido externamente por una concha formada por dos valvas articuladas, las cuales son secretadas por el manto. La importancia ecológica de este grupo está determinada por su amplia distribución geográfica y batimétrica y porque suele ser el grupo dominante entre las comunidades de invertebrados bentónicos, con un importante papel en la trama alimentaría y en el equilibrio ecológico de los ecosistemas donde habitan (2).

\section{I.1.1 CLASIFICACIÓN TAXONÓMICA}

Reino: Animal

Phylum: Mollusca

Clase: Bivalvia

Subclase: Pteriomorphia

Superorden: Lamellibranchia

Orden: Mytiloida

Familia: Mytilidae (Rafinesque, 1815)

Género: Perna (Retzius, 1788)

Dentro del género (Perna), se distinguen usualmente cuatro especies: el mejillón verde Perna viridis (Linnaeus, 1758), el mejillón marrón Perna perna (Linnaeus, 1758), el mejillón verde graso Perna canaliculus (Gmelin, 1791) y el mejillón español o mejillón verde del mediterráneo Perna picta (Born, 1780) (21, 36). 


\section{I.1.2 MORfOLOGÍA}

Como su clasificación taxonómica indica, P. viridis es un moluscos bivalvo, lo cual significa que presentan dos valvas o conchas. Estas son de similar tamaño, forma elíptica y estrecha en uno de sus extremos; constituidas principalmente de carbonato cálcico. Están fuertemente unidas por una ligadura o bisagra. Su color externo varía de verde a verde-azuloso brillante en los juveniles y a carmelita bronceado menos brillante en los adultos, aunque siempre mantienen un color verde-azuloso contorneando el borde de sus valvas. En su interior mantienen un color nacarado verde-azuloso $(21,36,37)$. La presencia de biso en forma de hilos en el bode de la concha le permite fijarse fuertemente al substrato duro (37).

En su interior contienen una masa suave, embebida en el líquido intravalvar y protegida por el manto, que delimita el volumen interno y se denomina cavidad paleal. Presentan un músculo aductor posterior en forma de riñón, adherido a ambas conchas en su interior, que le permite abrir y cerrar estas $(6,36,37)$. Son pocas las características que distinguen a $P$. viridis del resto de las especies pertenecientes a este género $(21,36,38)$. La más significativa es la presencia de una papila sensorial elongada a lo largo de los bordes del manto (36).

\section{I.1.3 ALIMENTACIÓN}

P.viridis es una especie filtradora eficiente. Firmemente atados a un sustrato, los mejillones inmóviles atraen el agua con el alimento suspendido mediante acción ciliar a través de su sifón inhalante, alimentándose principalmente de zooplancton, fitoplancton y detritos (6). Después de una apropiada clasificación de las partículas por tamaño en las branquias, pasan a la boca para la ingestión y posterior digestión, descargando el agua absorbida por el sifón exhalante (39). De esta forma los bivalvos pueden presentar tasas de filtración desde 0.1 hasta $4 \mathrm{~L} / \mathrm{h} /$ animal (40).

\section{I.1.4 CRECIMIENTO}

El mejillón verde tiene un tiempo de vida de aproximadamente de 3 años (41). Los primeros 4 meses puede llegar a crecer entre 40 - $50 \mathrm{~mm}$ de largo $(42,43,44)$, con una tasa de crecimiento promedio por mes de $6-10 \mathrm{~mm}$ (41), aunque pueden variar su conducta en dependencia de factores ambientales (44). Son capaces de sobrepasar estos valores si las condiciones les son 
favorables. Este es el caso de la bahía de Tampa donde se reportaron tasas de 4 a $5 \mathrm{~mm}$ por semana (41). Su crecimiento es concéntrico, marcado por los anillos de su concha y logran alcanzar tallas en la adultez de 80 a $100 \mathrm{~mm}$. En ocasiones se han reportado tamaños de más de $160 \mathrm{~mm}(21)$.

\section{I.1.5 REPRODUCCIÓN}

Esta especie presenta sexos separados, lo que no puede distinguirse por su apariencia externa. Comienzan su madurez sexual con tallas entre 15 y $30 \mathrm{~mm}$, alrededor de los 2 a 3 meses de edad (6, 36). El tejido gonadal en ambos sexos invade y recubre todo su cuerpo, imprimiéndoles un color anaranjado- rojizo brillante a hembras y blanco- cremoso lechoso a los machos (45). El desove es de forma sincronizada, expulsando los gametos al agua, donde ocurre la fertilización, aunque otros autores plantean que es asincrónico (46). Generalmente se producen dos picos reproductivos por año en zonas tropicales, al inicio de la primavera y tarde en el otoño (mayo - septiembre) y uno en zonas subtropicales (21).

\section{I.1.6 HÁBITAT}

Generalmente $P$. viridis habita en ambientes estuarinos $(6,21)$ con temperaturas de 26 a $32{ }^{\circ} \mathrm{C}$, salinidades entre 27-33 psu y concentraciones de oxígeno disuelto entre 4 y 7 mg/L, valores óptimos para su crecimiento (41), aunque puede tolerar variaciones de estos rangos por determinados períodos no muy largos de tiempo $(21,47)$. Es una especie característica de la fauna en aguas del litoral y el sublitoral, donde constituye a menudo poblaciones densas, favorecidas por las altas concentraciones de plancton y materia orgánica suspendida (6). Tiene un comportamiento gregario, formando grandes racimos al agruparse unos junto a otros con la ayuda de su bien desarrollado bisal (21). Los mejillones colonizan las superficies rocosas y las estructuras sumergidas de: madera, hormigón, metal, PVC y otras como sogas, tuberías, boyas, las raíces de los mangles, entre otras. Juegan un importante papel en los ecosistemas playeros de orillas rocosas $(6,38)$. Las mayores densidades de este molusco se encuentran entre los 2 y 4 $\mathrm{m}$ de profundidad y el valor óptimo es alrededor de los $3 \mathrm{~m}(6)$. 


\section{I.2 DiSTRIBUCIÓN GEOGRÁFICA}

P. viridis es una especie nativa de la región del Indo-Pacífico, distribuida por las costas de la India y del sudeste de Japón y China $(6,21)$. También se localiza en el Golfo Pérsico y en las costas de Indonesia hasta Nueva Guinea (36) y en algunas islas del Pacífico donde se introdujo de forma experimental (6). Sin embargo, esta especie disfruta de una amplia distribución por el mundo (21). Recientemente se ha introducido accidentalmente en varias regiones del Atlántico centro-occidental y el Caribe: Trinidad (48), Venezuela (49), Jamaica (50) y Florida en U.S.A. $(47,51)$; por lo que actualmente se le considera una especie exótica invasora (52).

\section{I.2.1 ESPECIE EXÓTICA INVASORA}

Las especies exóticas invasoras son consideradas en el mundo entero como el segundo motivo de extinción de especies, después de la pérdida de hábitat. Esto se debe a que pueden causar graves daños a los ecosistemas y provocar desequilibrios ecológicos entre las poblaciones de especies silvestres, cambios en la composición de especies y en la estructura trófica, desplazamiento de las especies nativas, pérdida de biodiversidad y la posible transmisión de enfermedades (19).

Especie exótica invasora, está definida por la Convención sobre Diversidad Biológica (52), como:"Especies no nativas que son introducidas deliberadamente o de manera accidental por fuera de su hábitat natural donde éstas se establecen, proliferan y dispersan de tal forma que causan daños a los intereses del hombre".

\section{I.3 CARACTERÍSTICAS DEL MEJILLÓN COMO ALIMENTO}

\section{I.3.1 CAPTURAS Y CONSUMO DEL MEJILLÓN VERDE P. VIRIDIS}

Desde la antigüedad son famosos algunos bivalvos comestibles, como los ostiones, las almejas y los mejillones. En los trópicos se pueden recolectar en forma natural y cultivar de manera relativamente barata, siendo esto una tradición para muchos países de Asia y el Pacífico, lo que proporciona una fuente fácil de alimentos. Hace mucho tiempo, los moluscos también fueron un alimento económico para los pueblos de pescadores en muchos países europeos. Sin 
embargo en la actualidad son artículos caros, prácticamente de lujo, en Europa y América del Norte. Esto ha dado paso al desarrollo de la industria y su cultivo a nivel mundial (1).

La producción mundial de moluscos bivalvos ha aumentado considerablemente en los últimos sesenta años, pasando de casi un millón de toneladas en 1950 a unos 14 millones de toneladas en 2010. China es el principal productor de moluscos bivalvos seguido por Japón, los Estados Unidos de América, la República de Corea, Tailandia, Francia, España, Italia y Chile. En América Latina y el Caribe, Chile es el mayor productor en la región seguido por Brasil y Perú. Las principales especies que se producen son el mejillón chileno y la concha de abanico. Además México y Cuba han reportado producciones de ostión que superan las 1000 toneladas (22, 53, 54). Tradicionalmente, la especie preferida para el consumo por los cubanos, es el ostión de mangle (Crassostrea rhizophorae, Guilding 1928), uno de los moluscos más conocidos y estudiados en nuestro territorio (2). Llegó a desarrollarse como cultivo en los años 80 y alcanzó producciones que representan entre un 4 y un $6 \%$ de las capturas totales de especies marinas. En los últimos años, los volúmenes de captura se han mantenido estables, aunque no sobrepasan las 100 toneladas anuales de masa limpia (3). La demanda de ostiones es de consideración y, tradicionalmente, éstos se han expedido en forma de cócteles en pequeños establecimientos, donde su consumo es muy popular, en gran medida, porque se le atribuyen propiedades afrodisíacas.

El mejillón verde constituye un recurso económico de interés y una importante fuente de proteínas para la población del sureste asiático (4), debido a sus altos rendimientos en comparación con cualquier otro bivalvo cultivado (5). Se ha observado que los rendimientos de este molusco, cultivados en cuerdas suspendidas de balsas, durante cinco meses, ascienden a 10 y $12 \mathrm{~kg} / \mathrm{rn}$ de cuerda, en una variedad de países de la región. Se plantea que el rendimiento de proteína de alta calidad nutritiva por hectárea de superficie de agua, supera considerablemente la proteína que podría producirse en una hectárea de tierra, cualquier planta o animal terrestre conocido (1). Los mayores productores de esta especie en la región son: India, Malasia, Filipinas, Singapur y Tailandia; donde se alcanzó un pico en las capturas provenientes del medio natural en los años 70, seguida de una depresión en los 90 y un auge de su producción a través de la acuicultura en los 2000, como se puede observar en los siguientes gráficos (55). 
Producción Global por Captura

de Perna viridis

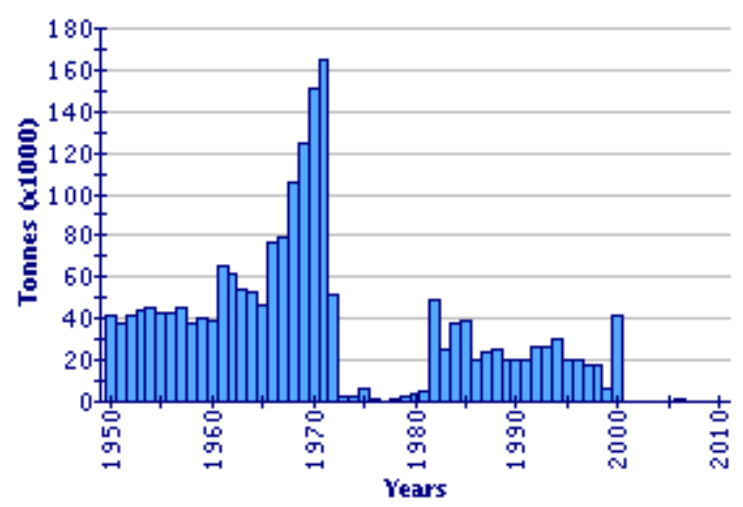

Producción Global por Acuicultura

de Perna viridis

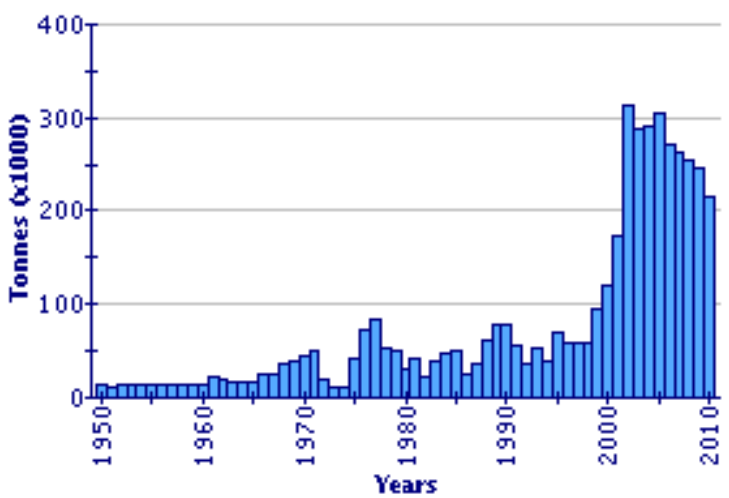

Figura 1: Producción Global de P.viridis por capturas y cultivos. Modificados a partir de: FAO FishFinder, 2012 (55).

\section{I.3.2 FORMAS DE PRESENTACIÓN Y COMERCIALIZACIÓN}

Los mejillones se comercializan principalmente vivos, frescos y refrigerados, en menor cuantía congelados, seguidos de enlatados y curados. Los vivos siempre van con cáscara o ambas conchas. Los frescos pueden ser en media concha o pulpa (masa). Los congelados pueden tener las presentaciones de los vivos y los frescos, además pueden ser pulpa cocida. También están los que presentan un valor agregado como: ahumados, pulpa enlatada, sopas enlatadas, fritos, entre otros (56). Se clasifican por tallas e integridad de las piezas, seguido de la depuración y el empaquetado, que puede ser fresco-enhielado y congelado, al vacío o en atmósfera modificada. En dependencia de las tallas, estará su forma de comercialización y su valor en el mercado, siendo los más caros los de mayores y medianas tallas que generalmente se comercializan vivos $\mathrm{y}$ frescos (57).

\section{I.3.3 COMPOSICIÓN QUÍMICA Y NUTRICIONAL}

La composición proximal de los moluscos depende de diversos factores exógenos o ambientales como: estacionalidad, zona de captura, temperatura, salinidad, profundidad, disponibilidad y calidad del alimento, forma de cultivo, entre otros; así como de factores endógenos como: el estado fisiológico, talla, edad, sexo y etapa reproductiva del animal (23, $58,59,60)$. 
Acosta en el 2010, en un estudio periódico de los componentes bioquímicos de los tejidos del mejillón Perna viridis; encontró una tendencia a la disminución de carbohidratos y proteínas, relacionada con los estadios de desarrollo y madurez sexual, particularmente en el músculo y glándula digestiva, mostrando posibles movilizaciones hacia la gónada. Sin embargo los lípidos del músculo se mantuvieron relativamente estables, aunque disminuyeron en la maduración en este tejido y en todos los tejidos en el desove, al igual que las proteínas (61). Esto se corrobora con la práctica de su consumo, que se realiza principalmente cuando el bivalvo alcanza la madurez sexual y están próximos a efectuar su reproducción (42).

En este mismo estudio se demostró cómo los factores ambientales estresantes, como altas temperaturas y baja disponibilidad de alimento, debido a la estratificación de la columna de agua, pueden incidir en el buen desarrollo de los mejillones y en su calidad. Se observó un patrón de crecimiento más lento, expresándose tanto en la dimensión de la concha como en la masa de los tejidos (61). Sin embargo otros estudios plantean, que la calidad y disponibilidad del alimento pueden ser un factor determinante para el buen desarrollo fisiológico del mejillón, dándole herramientas para enfrentar situaciones de estrés en periodos de estratificación (62).

No obstante los cambios que puedan existir en su composición, en relación con los factores antes mencionados, los mejillones de la familia Mytilidae son una buena fuente de macroelementos (mg/100g) como: Sodio (140-280), Potasio (315-480), Calcio (52-164), Fósforo (102-236) y Magnesio (23), así como microelementos (ppm) como: Hierro (169), Zinc (36), Cobre (9.5), Manganeso (4.36) y Yodo (0.9). El contenido en cenizas es mayor que en peces y crustáceos $(1 \pm 0.5 \%)$, debido a que se consume todo su cuerpo. También son una importante fuente de vitaminas como: Vit. A (156 UI), Riboflavina (150 $\mu \mathrm{g})$, Tiamina (20 $\mu \mathrm{g})$, Vit $\mathrm{B}_{12}(10.2 \mu \mathrm{g})$, Niacina $(1.6 \mathrm{mg} / 100 \mathrm{~g})$, Acido ascórbico $(7.5 \mathrm{mg})$ y Acido fólico (41.8 $\left.\mu \mathrm{g}\right)$ (23).

Por otra parte, presenta un aceptable contenido en proteínas (7.6 - 15.7 g/100 g) (63), de buena calidad biológica, tanto por la presencia de todos los aminoácidos esenciales, como por su alta digestibilidad (Histidina 1.8, Isoleucina 5.2, Leucina 6.2, Lisina 7.7, Metionina 2.3 y Cisteina 1.5, Fenilalanina 3.9 y Tirosina 3.7, Treonina 4.3, Triptófano 1.0 y Valina $6.1 \%$ del total de proteínas para músculo cocido). Además aportan aminoácidos no esenciales como: Arginina 
7.3, Ac. Aspártico 9.1, Serina 5.2, Ac. Glutámico 11.6, Prolina 3.5, Glicina 6.0 y Alanina $5.1 \%$ del total de proteínas para músculo cocido (23).

Su contenido en lípidos es relativamente bajo (1 - $3.2 \mathrm{~g} / 100 \mathrm{~g})$ (23), dentro de los cuales se describen ácidos grasos polinsaturados, fundamentalmente del tipo $\Omega_{3}(64)$. No obstante, se plantea que presentan una proporción ventajosa $\Omega_{6} / \Omega_{3}$ igual a 0.2 (65). Los mejillones de esta familia presentan un contenido en colesterol relativamente bajo (55 - $63 \mathrm{mg} / 100 \mathrm{~g}$ ), a diferencia de otros moluscos y crustáceos (ostiones 190, vieiras 116, calamar 283, camarón 158), donde el aporte en colesterol tiende a ser de 2 a 3 veces más alto que en pescado (23). Del mismo modo es su aporte en hidratos de carbono (entre 1 y $3 \%$ ), principalmente por su contenido en glucógeno. Este alimento tiene un bajo índice glucémico y aporta pocas calorías (70 a 90 calorías por $100 \mathrm{~g})(23,65)$

\section{I.4 FACTORES QUE PUEDEN AFECTAR LA INOCUIDAD DE LOS MOLUSCOS BIVALVOS}

La inocuidad de los alimentos ha sido definida por el Codex Alimentarius, como "la propiedad de asegurar que los alimentos no vayan a causar daño al consumidor cuando este sea preparado y/o consumido de acuerdo con el uso que debería dársele” (34). También la FAO y la OMS, hacen referencia a "todos los riesgos, sean crónicos o agudos, que pueden hacer que los alimentos sean nocivos para la salud del consumidor" (35).

Son diversos los factores que pueden afectar la inocuidad de los moluscos bivalvos. La característica innata que los hace más vulnerables que otros organismos acuáticos, es su forma de alimentación, que como ya se ha descrito, es a través de la filtración del agua donde viven. Esto les da la capacidad de bioacumular todo tipo de contaminante que haya en el medio, tanto de origen biológico (bacterias, virus y parásitos), como de origen químico, natural (biotoxinas) y artificial (metales pesados, plaguicidas, hidrocarburos, entre otros) (7, 8). Por tanto el factor más importante que incide en su inocuidad es la calidad de las aguas donde se desarrolla, agravado por las formas habituales de consumo (crudo o semicocido), lo que puede originar diversos riesgos a la salud humana (1). 
Tal es su capacidad de filtración, que son usados como depuradores de aguas residuales de la acuicultura para disminuir el impacto ambiental que genera el vertimiento de fitoplancton, zooplancton, bacterias y nutrientes disueltos, entre otros residuos. Son utilizados bajo el concepto de biorremediación tanto en tuberías de drenaje como en poli cultivos (66). Un ejemplo lo constituye el estudio realizado por Lin y colaboradores en 1993, del cultivo de Perna viridis en los canales de drenaje de estanques de cultivo intensivo de camarón Litopenaeus vannamei (67). En otros casos son utilizados como bioindicadores, biosensores o biomonitores de la contaminación en ambientes naturales $(8,9,10,11,12,68)$ y en condiciones de laboratorio $(69,70)$. No sólo por las concentraciones de contaminantes que puedan acumular en sus tejidos, sino por la presencia de biomarcadores específicos e inespecíficos, que son parámetros biológicos seleccionados para expresar una alteración o daño real que un organismo está sufriendo por exposición o acción de un tóxico o grupo de ellos $(9,11,71)$.

\section{I.4.1 MiCROBIOLÓGICOS}

Los moluscos llevan una población microbiana "residente" que oscila entre $10^{4}$ y $10^{6}$ bacterias/g de tejido. Los recuentos más altos se presentan cuando la temperatura del agua es alta. Como normalmente se recolectan en zonas de estuarios, que en su mayoría reciben ciertos materiales de desecho de origen terrestre, es frecuente que presenten un pequeño número de coliformes que no forman parte de la población microbiana residente normal. Durante la alteración de los moluscos, la población microbiana aumenta generalmente hasta $10^{7} \mathrm{ufc} / \mathrm{g}$ ó más. En su microbiota predominan los bacilos gram-negativos de los géneros Vibrio, Pseudomonas, Acinetobacter-Moraxella (Achromobacter), Flavobacterium y Cytophaga. Esta parece ser la población residente de los moluscos; también existen en menor número microorganismos gram-positivos. En una reciente investigación donde estudiaron la actividad enzimática de bacterias frecuentes en Perna viridis congelados, encontraron que las bacterias mesófilas y psicrotróficas mayoritarias fueron Micrococcus nishinomiyaensis y Acinetobacter spp., respectivamente. Así mismo, la única enterobacteria que se aisló fue Erwinia sp. (72, 73).

En los moluscos bivalvos pueden estar presentes bacterias entéricas patógenas procedentes de aguas residuales humanas o animales, incluidos los géneros Salmonella, Shigella, Vibrio y Coliformes (13). Se hospedan corrientemente en el canal alimenticio del molusco. En un 
estudio de alimentos tradicionales como ostras crudas (Pinctada imbricada) y pepitotas (Arca zebra) en una región de Venezuela, se encontraron altos recuentos de coliformes fecales y un porciento elevado de cepas enteropatógenas de E. coli, demostrando el origen fecal de la contaminación (74). También fueron aisladas de mejillones Perna perna y P. viridis del estado Sucre, enterobacterias como: Klebsiella pneumoniae y K. oxytoca; Enterobacter cloacae, E. aerogenes y E. agglomerans; Citrobacter freundii; Proteus mirabilis y P. vulgaris; E.coli y Salmonella spp. Cuatro de estas bacterias también fueron encontradas en las agua de extracción, corroborando la posible concentración de bacterias patógenas provenientes del medio (75). Clostridium perfringens ha sido utilizado como indicador de contaminación fecal en esta misma zona de cultivo, clasificándolo como excelente indicador de este tipo de contaminación por no formar parte de la microbiota de ambientes marinos (76). En bivalvos Arca zebra y Perna perna del mismo estado, se aislaron bacterias del genero Vibrio spp. (77).

Como hemos reseñado anteriormente, son diversos los agentes etiológicos que pueden estar presente en los moluscos bivalvos, y en consecuencia las enfermedades trasmitidas por estos alimentos (ETA) son igualmente disímiles. Las que con mayor frecuencia se presentan son: Salmonelosis, Intoxicación estafilocócica, Intoxicación por Clostridium perfringens, Shigelosis, Intoxicación por Vibrio parahaemolyticus, Cólera, Intoxicación por Bacillus cereus, Diarreas de los viajeros, Colitis hemorrágica y Diarreas (causadas por diferentes especies de $E$. coli). Los principales síntomas son: diarreas, vómitos, deshidratación, fiebre, dolores de cabeza, pérdida de apetito. También existen otras ETAs con síntomas más específicos como Listeriosis (meningoencefalitis, septicemia o ambas) y Botulismo (cuadro neurológico con parálisis respiratoria) $(7,14)$.

Los virus no se multiplican en los alimentos, pero son un vehículo pasivo de transmisión. Sin embargo dada las características de los moluscos bivalvos, pueden concentrarlos provenientes de las aguas donde habitan, encabezando la lista de los vehículos alimentarios en los brotes de enfermedades virales. En la actualidad se sabe que hay más de 100 virus entéricos que son excretados en las heces humanas y que van a parar a las aguas residuales domésticas. No obstante, se ha demostrado que tan sólo unos pocos son los causantes de enfermedades relacionadas con productos pesqueros (Hepatitis tipo A, Virus Norwalk (NLV), Agente nieve de montaña, Calicivirus, Astrovirus) (13). Los principales virus que causan brotes de 
enfermedad asociados al consumo de moluscos son: el grupo del virus de NLV y el virus de la hepatitis A.

El grupo del virus de Norwalk, debe su nombre a la localidad donde ocurrió el brote epidémico por primera vez. En la actualidad a este síndrome se le denomina "gastroenteritis epidémica no bacteriana". La gastroenteritis producida por los virus del género NLV, presenta síntomas asociados como: vómitos, diarrea acuosa no sanguinolenta, dolor abdominal, fiebre y náuseas, con un período de incubación de entre 1 y 4 días. Generalmente, la recuperación es completa y sin complicaciones tras ese período. Las muertes asociadas a infecciones por NLV son infrecuentes, aunque hay casos descritos en ancianos. NLV afectan tanto a niños como a adultos y están considerados como la causa principal de gastroenteritis en el mundo (78).

La hepatitis infecciosa producida por el virus de la hepatitis A, es la infección viral más seria asociada al consumo de moluscos, produciendo una enfermedad muy debilitante e incluso, de modo ocasional, la muerte. Desde el primer brote documentado producido por consumo de ostras, ocurrido en Suecia en 1955, se han descrito numerosos casos de hepatitis A transmitidos por este tipo de alimentos en todo el mundo. En la sintomatología asociada a la hepatitis infecciosa se pueden diferenciar una primera fase inespecífica con fiebre, dolor de cabeza y náuseas, y una fase final que incluye vómitos, diarrea, dolor abdominal e ictericia. La edad parece ser un factor importante en la severidad de la enfermedad, siendo más leve en niños que en adultos (78).

\section{I.4.2 CONTAMINANTES QUÍMICOS}

Los contaminantes químicos en los alimentos pueden ser muy variados, tales como: metales tóxicos, plaguicidas, hidrocarburos, elementos radioactivos, antibióticos, hormonas, etc. Pueden llegar a la biota a través de fuentes naturales o antropogénicas; bioacumulándose, biotransformándose y biomagnificándose a través de la cadena alimenticia. Pueden resultar en serios problemas por intoxicaciones para el hombre y los ecosistemas. Los grupos más persistentes por su estabilidad química son: los metales pesados, los plaguicidas e hidrocarburos (79). Al igual que en la composición proximal de los moluscos, la acumulación de contaminantes químicos se ha relacionado con factores exógenos o ambientales y 
endógenos. Existen variaciones en los niveles de acumulación entre sexos, por el estado reproductivo, por tallas, por la estacionalidad (periodos de lluvia o seca) y por la variación de la temperatura entre otros factores $(10,11)$. Esto evidencia la complejidad de interrelaciones que existe entre estos seres vivos y el ambiente que los rodea.

\section{I.4.2.1 METALES PESADOS}

Los metales más peligrosos tanto para el ecosistema marino como para la salud humana debido a sus características de toxicidad, persistencia y bioacumulación son: Mercurio, Cadmio, Plomo, Arsénico, Berilio y Bario. También se encuentran: Calcio, Potasio, Sodio, Magnesio,

Hierro, Zinc, Selenio, Manganeso, Cobre, Molibdeno, Cobalto, Cromo, Sílice, Níquel; que juegan un papel importante en el metabolismo normal, siempre que se encuentren a las concentraciones requeridas por el organismo. Algunos metales como: Plomo o Mercurio, pueden considerarse como tóxicos sistémicos, es decir que pueden afectar a más de un órgano, si son ingeridos (sistema gastrointestinal) y distribuidos a diferentes órganos por la sangre. La toxicidad de un metal depende de la dosis en que se ingiera, así como de la cantidad excretada. A veces la diferencia entre la concentración tóxica y la concentración requerida es mínima, como sucede en el caso del Selenio. También es importante el estado nutricional de los individuos expuestos $(79,80)$.

Ciertos metales tienen un comportamiento biogeoquímico muy similar al de los nutrientes. Se concentran en la materia orgánica, sedimentos, nódulos de manganeso y fosforitas marinas, estando biodisponibles para organismos consumidores, al enriquecer las aguas costeras en periodos de surgencia (10). Su bioacumulación depende de la existencia o no de receptores específicos para cada metal, de la afinidad de estos receptores y la especiación del metal. También está influenciado por los diferentes estados de oxidación y por la unión a moléculas orgánicas, que puede favorecer su paso a través de la membrana plasmática. Otros metales son acumulados en forma inerte en gránulos intracelulares, disminuyendo así su concentración aparente (81).

$P$. viridis, ha demostrado ser un buen bioacumulador de metales, tanto en condiciones de laboratorio como en ambiente natural $(69,70)$. Investigaciones recientes muestran su capacidad 
de acumular metales e hidrocarburos, al ser usados como sensores de contaminación en aguas costeras de zonas portuarias y no portuarias, en la península de Malasia. En este estudio los valores más significativos fueron para Cd (1.58 ug/g peso seco) y PHAs (244 ng/g peso seco), en la zona de mayor contaminación (portuaria) (12). En la península de Araya, Venezuela, se analizó la relación entre concentración de metales, variaciones estacionales y el sexo en esta especie, y se encontró que los niveles más altos de $\mathrm{Zn}$ y $\mathrm{Ni}$ fueron en época de lluvia y $\mathrm{Cu}, \mathrm{Cr}$, $\mathrm{Cd}$ y $\mathrm{Pb}$ en época de seca. Las hembras presentaron mayores concentraciones de $\mathrm{Cu}, \mathrm{Cd}$ y $\mathrm{Ni}$ que los machos, lo que se relacionó con el mayor desarrollo gonadal en hembras (11). Otro ejemplo lo constituye una investigación realizada en este mismo estado, donde utilizan a P.viridis para comparar la contaminación de dos zonas costeras con respecto a una de referencia, y hallaron valores de $\mathrm{Cd}(5.58 \pm 1.62 \mathrm{ug} / \mathrm{g}$ peso seco) y $\mathrm{Pb}(0.12 \pm 0.20 \mathrm{ug} / \mathrm{g}$ peso seco) en la zona más contaminada (9).

Los estudios de esta especie bajo condiciones controladas, han permitido la evaluación de biomarcadores que permiten el uso de estos organismos, como especie centinela para evaluar la salud del ecosistema. Se ha establecido claramente, que este bivalvo activa mecanismos fácilmente cuantificables como es el incremento de metalotioninas, los niveles de glutatión y alteraciones electrolíticas, cuando son expuestos a metales como $\mathrm{Cu}, \mathrm{Cd}$ y $\mathrm{Hg}$. También se ha demostrado lisis celular y agregación, así como una disminución del número de hemocitos cuando están expuestos a cadmio, evidenciando una respuesta inmune significativa ante estas condiciones de estrés $(9,69,70)$. Por otra parte, la presencia de contaminantes orgánicos e inorgánicos en su entorno ha mostrado tener efectos significativos sobre el metabolismo oxidativo, bien sea por la inducción misma de especies reactivas de Oxígeno o como producto del metabolismo del xenobiótico (9). Bajo condiciones controladas las evaluaciones en algunas enzimas del metabolismo oxidativo revelan efectos significativos por exposición a metales e hidrocarburos. Todo lo anterior tiene validez siempre y cuando se conozcan claramente las variaciones fisiológicas a las que están sujetos estos organismos durante su ciclo de vida (82).

\section{I.4.2.1.1 METALES EMINENTEMENTE TÓXICOS}

Mercurio: puede estar presente en la naturaleza de diferentes formas, metálico o elemental, sales inorgánicas (al combinarse con Cloro, Azufre u Oxígeno) y compuestos orgánicos (etil, 
fenil y metilmercurio) (83). Los derivados orgánicos, son más tóxicos que el metal, en especial el metilmercurio (84), que se obtiene a partir de la biotransformación del Hg por varias bacterias presentes en el suelo o en el agua, entre las que se encuentra Methanobacterium amelanskis (79). El metilmercurio es más tóxico que el metal por presentar mejor absorción a través del tracto gastrointestinal. Puede inducir efectos tóxicos en varios sistemas y órganos (el sistema nervioso, riñón, el hígado, los órganos reproductores), siendo el sistema nervioso el más sensible. La neurotoxicidad causada por una excesiva exposición al metilmercurio, incluye: pérdida neuronal, ataxia, perturbaciones visuales, daños auditivos, parálisis y muerte. Se piensa que estos daños son más severos en edades tempranas cuando el cerebro está creciendo rápidamente, incluso se plantea que las afectaciones pueden comenzar con la exposición del feto a través de la placenta y extenderse en el desarrollo postnatal $(83,84)$. Las principales fuentes de mercurio son de origen industrial como: fábricas de papel, plantas de cloro, sosa o purificación de Oro (79). El límite máximo de residuo (LMR) permitido por la Comunidad Europea, es de $0.5 \mathrm{mg} / \mathrm{Kg}$ de peso fresco para productos de la pesca (85), similar al límite establecido por la norma cubana vigente para moluscos bivalvos (86).

Cadmio: Su estado de oxidación, en ambientes considerados naturales, es Cd (II) y no se afecta directamente por las condiciones Redox. Este metal puede formar cloruros y complejos orgánicos (87). Datos experimentales revelan que la absorción pulmonar es más elevada que la absorción gastrointestinal. El Cadmio absorbido por ambas vías, se acumula principalmente en el hígado y en los riñones. Además se acumula en la placenta, aunque pasa poco al feto. La acumulación de cadmio en el riñón produce disfunción renal. La excreción suele ser lenta, principalmente a través de la orina (88). El envenenamiento por cadmio en los seres humanos produce osteoporosis, enfisema pulmonar, cáncer de pulmón, cáncer de próstata, hipertensión, diversas cardiopatías y retraso en la habilidad verbal de los niños (89). También compite con otros metales como el zinc y el cobre. La Agencia Internacional de Investigaciones sobre el Cáncer (AIIC) en 1993, clasificó el Cadmio y los compuestos de cadmio, dentro del grupo 1: cancerígenos para los seres humanos $(16,88)$. La principal fuente de contaminación ambiental por cadmio es la roca fosfórica con alto contenido del metal, usada para la fabricación de fertilizantes (79). También se describen: las fundiciones, los productos de incineración de materiales que contienen cadmio, combustibles fósiles, fertilizantes, aguas residuales y descarga de lodo (80). El LMR que establece la Comunidad Europea para este metal, es de 1 
$\mathrm{mg} / \mathrm{Kg}$ de peso fresco (85), mientras que el límite que señala la norma cubana vigente es de 2 $\mathrm{mg} / \mathrm{Kg}(86)$.

Plomo: Es un metal de color gris-azulado en su forma pura, con baja temperatura de fusión. Entre sus compuestos derivados, con importancia económica, está el Tetraetilo de Plomo $\mathrm{Pb}$ $\left(\mathrm{C}_{2} \mathrm{H}_{5}\right) 4$, utilizado como antidetonante en gasolina (79). Su porcentaje de absorción puede oscilar entre 3 y $80 \%$, influido por la ingestión de alimentos. Su absorción aumenta después del ayuno con respecto a cuando se ingiere unido a la comida. Otro factor que influye es la edad, los porcentajes de absorción y retención típicos son menores en adultos que en niños. Después de su absorción y distribución en la sangre, inicialmente el plomo se distribuye a los tejidos blandos a través del cuerpo. Eventualmente, el esqueleto acumula plomo durante la mayor parte de la duración de la vida humana y puede servir como una fuente endógena durante períodos de deficiencia de calcio, como el embarazo, lactancia y osteoporosis (90). El Plomo inorgánico no se metaboliza y el que no se distribuye, se excreta principalmente a través del hígado (88). La toxicidad por este metal puede causar varios efectos no deseados como: perturbación de la biosíntesis de hemoglobina y anemia, incremento de la presión sanguínea, daño a los riñones, aborto espontáneo, perturbación del sistema nervioso, daño al cerebro, distintos tipos de cáncer, disminución de la fertilidad del hombre a través de daño en el esperma, disminución de las habilidades de aprendizaje de los niños, perturbación en el comportamiento de los niños (agresión, comportamiento impulsivo e hipersensibilidad), y también puede afectar al feto a través de la placenta de la madre, causando serios daños al sistema nervioso de los niños por nacer. La AIIC en el 2006, clasificó los compuestos de plomo inorgánico, dentro del Grupo 2A: como probablemente carcinógenos para el ser humano (16). La exposición al Plomo puede producirse por muchas fuentes, pero normalmente se produce por el uso industrial. Forma parte principalmente de baterías, cables, pigmentos, cañerías, gasolina, productos de soldadura y acero, envases de alimentos, vidrio, productos de cerámica y plaguicidas. Contamina el medio ambiente durante la minería, la fundición, procesado, utilización, reciclado o deshecho de materiales que lo contengan. $(79,88)$. El LMR que regula la Comunidad Europea para este metal es de $1.5 \mathrm{mg} / \mathrm{Kg}$ de peso fresco para moluscos bivalvos (85), del mimo modo se establece en la norma cubana vigente (86). 
Arsénico: Las formas más tóxicas del Arsénico son el Arsénico inorgánico (III) y los compuestos (V); el Trióxido de Arsénico es muy conocido como veneno para ratas y también se ha utilizado para cometer homicidios. Los metilados de Arsénico tienen una toxicidad aguda baja; la arsenobetaína, principal forma del Arsénico presente en el pescado y los crustáceos, se considera no tóxica. En los crustáceos, los moluscos y las algas, se presentan derivados del dimetilarsinoilribosido ("arsenoazúcares"), cuya posible toxicidad no se conoce con detalle (88). Este metal es fácilmente absorbido por el tracto digestivo y distribuido en el cuerpo como un complejo de proteína ( $\alpha$-globulina)-arsénico. Es un tóxico protoplasmático que se une a los grupos sulfhidrilo, inhibiendo a varias enzimas, especialmente las del metabolismo celular y las de la respiración. Posee un efecto de dilatación y aumento de la permeabilidad capilar del intestino. $\mathrm{Su}$ efecto crónico está relacionado con: pérdida de apetito, problemas gastrointestinales, conjuntivitis, hiperqueratosis y melanodermia (que puede repercutir en cáncer) (79). La AIIC ha clasificado el Arsénico inorgánico como carcinógeno humano. Se plantea la necesidad de más investigaciones sobre los resultados de la ingesta de los arsénicos orgánicos y de la posibilidad de que puedan convertirse en formas inorgánicas más tóxicas de arsénico, a través de la elaboración o del metabolismo en los animales o en los seres humanos (88). Este metal se encuentra en alimentos contaminados por fertilizantes fabricados a partir de roca fosfórica y por la contaminación accidental con plaguicidas. Otras fuentes pueden ser: el fundido de minerales, la incineración de carbón, su uso en conservadores de madera y medicamentos veterinarios o para seres humanos $(79,88)$. El LMR establecido para este metal por la norma cubana es de $1 \mathrm{mg} / \mathrm{Kg}$ de peso fresco para moluscos bivalvos (86).

\section{I.4.2.1.2 METALES ESENCIALES}

Los metales esenciales, son aquellos que el organismo no es capaz de fabricar y cuya ausencia produce un deterioro de la salud y posiblemente, en algunos casos, la muerte. Provocan mayormente problemas a la Salud Pública su ausencia o deficiencia que su exceso. No obstante elementos trazas como: Cobre, Hierro y Zinc, tienen una posible toxicidad, aunque no son comparables con la toxicidad que pueden producir otros metales no esenciales como: Plomo, Mercurio o Cadmio (91). Alimentos como los moluscos, en especial los bivalvos pueden ser peligrosos, por acumular en sus tejidos estos metales, sobre todo cuando se encuentran en zonas contaminadas $(9,70)$. 
Hierro: es de todos los elementos trazas esenciales para la vida el que se requiere en una mayor cantidad. Alrededor de 2/3 del Fe orgánico total corresponde al hierro funcional y la mayor parte se encuentra formando parte de la Hemoglobina ( $\mathrm{Hb})$ de los glóbulos rojos. El resto se encuentra en la mioglobina y otras enzimas con función enzimática que contienen hierro como cofactor. La otra porción del Fe es parte de la Ferritina y Hemosiderina, utilizadas para el depósito o transportación de este metal. Su principal función es la transportación de oxígeno, almacenamiento a nivel muscular y producción de energía (ATP) a nivel celular. Forma parte de los Citocromo P450 que intervienen en la degradación oxidativa de diversos compuestos o toxinas procedentes de fuentes externas y forma parte de varias enzimas que protegen contra la peroxidación lipídica. En dosis tóxicas en humanos, puede causar Necrosis hemorrágica del aparato gastrointestinal, con vómitos y diarreas sanguinolentas. La acumulación de hierro en exceso, puede ocasionar efectos adversos derivados de las lesiones producidas en hígado, corazón y páncreas principalmente (92). Existen dos tipos de intoxicación crónica por hierro: la hemocromatosis genética, idiopática o primaria y la hemocromatosis adquirida (secundaria) o hemosiderosis. La primaria, es una alteración hereditaria autosómica recesiva, donde un defecto de la mucosa de la pared intestinal provoca el aumento de la absorción de hierro proveniente de la ingesta. Esta alteración debuta entre la cuarta y quinta década de la vida y afecta más frecuentemente a hombres, con una relación de 10 a 1. La secundaria, se presenta en pacientes con anemia crónica y que han recibido transfusiones múltiples. Otras causas menos comunes son el déficit congénito de transferrina, cirrosis (alcohólica) $(93,94)$, ingesta excesiva de hierro, entre otras. La edad de presentación suele ser menor que en la primera. Las manifestaciones clínicas iniciales para ambas formas son: Diabetes mellitus, hiperpigmentación cutánea y enfermedad hepática. La hepatomegalia, es el signo más frecuente. La mayoría de los pacientes desarrollan cirrosis hepática, que puede degenerar a hepatocarcinoma. También puede presentarse afectación cardíaca con arritmias e insuficiencia cardíaca congestiva (95). Una de las recomendaciones nutricionales es no comer productos del mar crudos (96).

Cobre: Se encuentra en forma de $\mathrm{Cu}^{2+} \mathrm{y} \mathrm{Cu}^{1+}$. Forma parte de la estructura de 14 enzimas, esenciales para el metabolismo, como son: las citocromo oxidasas (respiración celular), superóxido dimutasas, ceruloplasmina y tioneínas (reacciones de defensa antioxidante). Además es cofactor de enzimas que intervienen en la polimerización de aminoácidos para la 
formación de diferentes tejidos y hormonas, forma parte de factores de coagulación, interviene en el buen funcionamiento del metabolismo del hierro y en la inactivación de aminas bioactivas. Los efectos tóxicos se producen por la generación de radicales de oxigeno por los quelados del $\mathrm{Cu}^{+}$(97). A dosis muy altas puede ser perjudicial, ocasionando irritación de la nariz, la boca, los ojos y causar dolores de cabeza, mareo, náuseas y diarrea (98). Su ingestión excesiva es poco frecuente, en casos de niños que accidentalmente han ingerido $\mathrm{CuSO}_{4}$ (pesticida) o por ingestión crónica, se ha descrito cirrosis hepática. También puede provocar lesiones en riñones, encéfalo y hemólisis de eritrocitos. En especial es peligroso para las personas que padecen la enfermedad de Wilson (defecto genético autosómico recesivo del metabolismo), que presentan deficiencia o ausencia de la enzima (ATPasa tipo P), que determina una incapacidad del hígado para exportar el $\mathrm{Cu}$ a la circulación y para excretarlo por las bilis. Por esta razón las fuentes naturales de $\mathrm{Cu}$ a través de los alimentos les resultan excesivas y lo acumulan, principalmente en cerebro, hígado y córnea (97, 99). La toxicidad crónica de origen ambiental es infrecuente y causa cirrosis hepática (99). Se encuentra de manera natural en las rocas, el agua (más abundante en agua de mar que en dulce), los sedimentos y muy poco en el aire. Puede entrar al medio ambiente como resultado de la liberación de las minas de cobre, así como de fábricas que manufacturan o usan el cobre metálico, del agua residual doméstica, la combustión de desperdicios y combustibles fósiles (98).

Zinc: Después del Fe es uno de los elementos esenciales más abundantes en el cuerpo humano junto al $\mathrm{Cu}$. Presenta dos estados de oxidación $\mathrm{Zn}^{0}$ (metálico) y $\mathrm{Zn}^{+2}$. $\mathrm{El} \mathrm{Zn}^{+2}$, es un fuerte aceptor de electrones, no presenta propiedades Redox, por lo que, a diferencia del Cu no genera radicales libres. Forma parte de numerosos sistemas enzimáticos. Tiene roles insustituibles en sistemas enzimáticos de división y multiplicación celular y con los sistemas metabólicohormonales de regulación. La toxicidad crónica se da con ingestas diarias de más de $150 \mathrm{mg}$ por un período de tiempo prolongado. Los efectos incluyen: anemia sideroblástica causada por deficiencia de cobre, reducción de lipoproteínas de alta densidad, disminución de la actividad ferroxidasa sérica de la ceruloplasmina y depresión del sistema inmune (disminución de la estimulación de la fitohemaglutinina sobre los linfocitos). La toxicidad aguda se produce muy rara vez, con ingestas de entre 225 a $450 \mathrm{mg}$ y otros autores plantean que con más de 2 g/Kg de peso corporal, de una sola vez, y produce: dolor abdominal, diarrea, náusea y vómitos (99). Las 
fuentes de contaminación del medio ambiente más importantes, son: las industrias de galvanización del hierro y acero, la automovilística, construcción de equipos de oficina y utensilios de cocina. También se utilizan grandes cantidades en la obtención de aleaciones, y en polvo se utiliza como agente reductor (92).

\section{I.4.2.2 COMPUESTOS ORGÁNICOS PERSISTENTES}

Los contaminantes orgánicos persistentes (COP), se caracterizan por ser muy estables, resistentes a la degradación química, biológica y fotolítica. Son semi-volátiles, se evaporan con dificultad. Presentan baja solubilidad en agua. Su afinidad por los medios hidrocarbonados, determina su bioconcentración en los tejidos grasos, y biomagnificación a lo largo de la cadena trófica. Todas estas características los hacen persistentes en el medio ambiente, donde se han esparcido y representan un problema de contaminación global, debido a sus propiedades tóxicas tanto para humanos como para la flora y la fauna $(100,101,102)$.

El Programa de las Naciones Unidas para el Medio Ambiente, adoptado por 103 países en 1994, contempla la reducción de 12 sustancias conocidas como COP. En el 2001, se llega a un acuerdo global con el objetivo de proteger la salud humana y el medio ambiente frente a estos compuestos (El convenio de Estocolmo). En él se plantea eliminar, y cuando esto no sea posible regular y reducir, las emisiones y las descargas de estos contaminantes. El grupo de sustancias reguladas, denominada la docena sucia, incluye: los plaguicidas organoclorados (DDT, Aldrin, Dieldrin, Endrin, Clordano, Heptacloro, Toxafeno, Mirex), productos industriales (bifenilos policlorados (PCBs) y Hexaclorobenceno) y contaminantes no deseados resultados de otros procesos (Dioxinas y Furanos). El convenio se firmó por más de 120 países y entró en vigor a partir del $2004(102,103)$.

\section{I.4.2.2.1 HIDROCARBUROS AROMÁTICOS POLICÍCLICOS}

Los hidrocarburos aromáticos policíclicos (HAPs) están formados por la fusión de al menos dos anillos aromáticos de benceno. Su solubilidad en agua es muy reducida y disminuye con el aumento del peso molecular y número de sustituciones. Su volatilidad es también muy baja. Son los hidrocarburos más tóxicos del petróleo y tienen una elevada persistencia y gran afinidad por los tejidos grasos, lo que favorece su bioacumulación. La norma general es que a 
mayor tamaño, mayor hidrofobicidad, y por lo tanto mayores factores de bioacumulación. Sin embargo, los hidrocarburos con mayor disponibilidad para los bivalvos filtradores, son los situados en la fracción disuelta (columna de agua) o particulada (alimento), mientras que los situados en el sedimento tienen una biodisponibilidad menor, salvo en el caso de resuspensión de este (81). Existen dos tipos de fuentes antropogénicas de HAP, petrogénicas y pirogénicas. Las petrogénicas incluyen el petróleo crudo y refinado. Ambos llegan a los ambientes acuáticos a través de los derrames accidentales en su transportación, derivados de actividades de la industria petroquímica y del escurrimiento urbano. Los pirogénicos, se generan por la combustión incompleta o pirolisis de materia orgánica (carbón, petróleo, gasolina, basura, tabaco y carnes) y en numerosos procesos industriales $(104,105)$.

En el 2011, la Comisión Técnica Científica de Contaminantes de la Cadena Alimentaria (CONTAM) perteneciente a la Autoridad Europea de Seguridad Alimentaria (EFSA) emitió un nuevo dictamen sobre la determinación de los HAP en los alimentos, al concluir que el benzo(a)pireno ( $\mathrm{BaP}$ ) no es un marcador adecuado de la presencia de este grupo de compuestos (106). En cambio, un sistema de cuatro sustancias específicas; benzo(a)pireno, criseno, benzo(a)antraceno y benzo(b)fluoranteno (HAP4) u ocho sustancias específicas; benzo(a)pireno, criseno, benzo(a)antraceno, benzo(b)fluoranteno, benzo(k)fluoranteno, benzo(g,h,i)perileno, dibenzo(a,h)antraceno e indeno(1,2,3-cd)pireno (HAP8) serían los indicadores más adecuados (107). Estos compuestos están categorizados por la Agencia de protección ambiental de los Estados Unidos, como posibles carcinógenos humanos en el Grupo 2, por su probada carcinogenicidad en animales. Están asociados con efectos tóxicos en los animales como: afectaciones del sistema reproductivo, cardiopatías, inmunosupresión y daños hepáticos y en la médula ósea (108). Aunque los efectos a la salud causados por cada uno de los HAPs individuales no son exactamente los mismos, en muchos se ha demostrado que son carcinógenos en animales y genotóxicos y mutagénicos en ensayos invitro. La AIIC, ha clasificado entre los 16 HPAs considerados como prioritarios, al benzo[a]pireno en el Grupo 1 como carcinógeno para los humanos, dos como probables carcinógenos para humanos, grupo 2A (dibenzo[a,l]pirenos, dibenzo[a,h]antraceno) y nueve como posibles carcinógenos para humanos (grupo 2B) (16, 105). Para moluscos bivalvos el límite máximo de residuo establecido por la Comunidad Europea es de $30 \mathrm{ug} / \mathrm{Kg}$ de peso fresco para los HPA4 y $5 \mathrm{ug} / \mathrm{Kg}$ de peso 
fresco para el Benzo(a)pireno (107), mientras que Cuba establece un LMR de $10 \mathrm{ug} / \mathrm{Kg}$ peso fresco para el Benzo(a)pireno (109).

\section{I.4 2.2.2 PLAGUICIDAS ORGANOCLORADOS}

Dentro del gran grupo de los plaguicidas son los insecticidas organoclorados (POCs) los más persistentes y tóxicos (110). Se clasifican en cuatro grupos de acuerdo a su estructura molecular: grupo del DDT y análogos (metoxicloro y pertano), hexaclorociclohexano e isómeros (lindano), ciclodienos (aldrín, endrín, dieldrín, clordano, endosulfán y heptaclor) y canfenos clorados (toxafén y clordecona) (101). Fueron usados ampliamente en la agricultura para el control de plagas y en salud pública para el control de enfermedades trasmitidas por vectores (110). Su uso está bien regulado, restringido y en la mayoría de los países prohibido. Sus efectos tóxicos agudos están relacionados con la estimulación del sistema nervioso central, con mareos, vómitos, convulsiones, entre otros síntomas; a través de la excitación neuronal, mediante la alteración de la permeabilidad de la membrana del axón (111). Su toxicidad crónica es la más preocupante por sus efectos desconocidos (112), aunque en los últimos años los estudios se han centrado en las consecuencias sobre la reproducción, neurotoxicidad y cáncer. El DDT y sus análogos, han sido los mas investigados, asociándolos con múltiples tipos de cáncer (linfoma Hodgkin y no-Hodgkin, leucemias, mieloma múltiple y sarcomas de tejidos blandos) (113).

En Cuba existen resoluciones prohibitivas con respecto al uso de plaguicidas, dictadas a partir del año 1990 por el Ministerio de Salud Pública (268/90, 181/95, 049/01, 002/04) y Ministerio de la Agricultura (007/06, 44/08). Dichos documentos prohíben el uso de: Aldrin, Canfeclor, Cihexatin, Clordimefon, Clorobencilato, Compuestos Inorgánicos de Arsénico y Mercurio, Compuestos Orgánicos de Mercurio, DDT, Dibromocloropropano, Dieldrin, Dinoseb y sus sales, Endrin, Fluoracetamida, Heptaclor, Hexaclorociclohexano, Leptofos, Monofluoroacetato de Sodio, Nitrofen, Pentaclorofenol, Clordano, Hexaclorobenceno, Dibromuro de Etileno, Clordecona, Mirex, Sulfato de Talio, 2,4,5-T, Monocrotofos, Dicloruro y Óxido de Etileno, Parathion, Fosfamidon y Formulaciones de Polvo seco de Benomilo (7\%) + Carbofuran (10\%) + Tiram (15\%) (114). 


\section{I.4.2.2.3 DiOXINAS/FuRANOS, POLICLOROBIFENILOS SIMILARES A LAS DIOXINAS Y POLICLOROBIFENILOS INDICADORES}

Con el nombre genérico de "Dioxinas" se conoce a un grupo de 210 compuestos orgánicos tricíclicos halogenados, cuyo grado de cloración y la posición de los átomos de cloro determinan la existencia de 75 congéneres de dibenzodioxinas (PCDDs) y 135 de dibenzofuranos (PCDFs). De éstos, 7 dibenzodioxinas y 10 dibenzofuranos, entrañan riesgos toxicológicos. El compuesto más tóxico es el 2, 3, 7, 8 - tetraclorodibenzo - para - dioxina (TCDD) y se utiliza como referencia para determinar la toxicidad del resto de las dioxinas (115).

Las dioxinas y furanos (PCDD/Fs) a diferencia de otros compuestos orgánicos persistentes, no son sintetizados industrialmente de manera intencionada. Se trata de subproductos no deseados en distintos procesos térmicos, como son la incineración de residuos, algunos procesos relacionados con el sector de la industria metalúrgica, en los hornos de cementeras y en la producción de energía (calefacciones, centrales térmicas), así como el blanqueado del papel y fabricación de herbicidas. Los PCBs, en forma de mezcla de congéneres comenzaron a usarse en los años 30 por su gran estabilidad química e hidrofobicidad, en líquidos hidráulicos, aislantes eléctricos en transformadores y agentes plastificantes en pinturas. Se plantea que $98 \%$ de estos compuestos se incorporan a los seres humanos a través de los alimentos (115). La AIIC clasifica a las dioxinas en el grupo 1 (cancerígenas para el ser humano) y a los PCBs en el grupo 2A (probable carcinógeno para el ser humano) porque producen efectos adversos en los animales, como toxicidad reproductiva, inmunotoxicidad y carcinogenicidad (16). Estos compuestos están regulados por la Comunidad Europea en su normativa vigente como: suma de Dioxinas y Furanos para productos de la pesca y acuicultura 3.5 pg/g de peso fresco y suma de Dioxinas y PCB similares a las dioxinas para productos de la pesca $6.5 \mathrm{pg} / \mathrm{g}$ de peso fresco ( ${ }^{\text {RECE1259/2011 }) . ~ S e ~ e s t a b l e c e ~ d e ~ i g u a l ~ f o r m a ~ p o r ~ l a ~ R e s o l u c i o ́ n ~ N o . ~ 538 / 12 ~ d e l ~ M i n i s t e r i o ~ d e ~ l a ~}$ Industria Alimentaria (109). Mientras que para la suma PCBs indicadores se establece un límite de $75 \mathrm{ng} / \mathrm{g}$ de peso fresco por la Comunidad Europea (116). 


\section{I.5 CARACTERÍSTICAS DE LA BAHÍA DE CIENFUEGOS}

La Bahía de Cienfuegos, ubicada al centro-Sur de Cuba $\left(22^{\circ} 09^{\prime} \mathrm{N}\right.$ y $\left.80^{\circ} 27^{\prime} \mathrm{O}\right)$, es una bahía de bolsa o semicerrada, con forma ovalada, lo cual influye en la dinámica y calidad de sus aguas, por comportarse generalmente como un sistema estuarino, con fuerte estratificación en época de lluvia. Orientada de noroeste a sureste, se extiende sobre un área de $88.46 \mathrm{~km}^{2}$, posee 100 $\mathrm{km}$ de costas irregulares y un volumen total de $1.84 \mathrm{~km}^{3}$. Tiene $19 \mathrm{~km}$ de longitud máxima y $7.5 \mathrm{~km}$ en su parte más ancha, con una profundidad promedio de alrededor de $9.5 \mathrm{~m}$. De forma natural está dividida en dos lóbulos, delimitados por el bajo Las Cuevas con una profundidad media de $1.5 \mathrm{~m}$; el cual ejerce gran influencia en la circulación de las masas de agua en el interior del ecosistema. Presenta además, un estrecho y sinuoso canal de acceso con una longitud de $3600 \mathrm{~m}$ y profundidades entre 30 y $50 \mathrm{~m}$ en su centro, que la comunica con el Mar Caribe $(27,117)$. Los principales afluentes de esta bahía son: Damují, Caunao, Salado, Arimao y Arroyo Inglés, que contribuyen a la modificación de su salinidad y al aporte de cantidades importantes de materia orgánica y contaminación (118).

Muchos son los autores que han aportado al conocimiento oceanográfico de esta bahía (27, 117, 119, 120). No obstante, en el 2011 se estudiaron las condiciones hidrológicas que pudieran estar influenciando la distribución y el desarrollo de esta especie foránea en este ecosistema. En el periodo lluvioso mayo-octubre, se encontró un máximo de precipitaciones en los meses de septiembre-octubre. La temperatura del agua mostró su pico máximo en el mes de mayo y su mínimo en febrero. Los valores oscilaron entre $23.30{ }^{\circ} \mathrm{C}$ (febrero) y $30.50{ }^{\circ} \mathrm{C}$ (mayo), con un valor medio por mes de $26.47 \pm 2.29{ }^{\circ} \mathrm{C}$. La estratificación de este parámetro fue mayor en el mes de noviembre con una diferencia entre la superficie y el fondo de $0.78{ }^{\circ} \mathrm{C}$. Los mayores valores de salinidad se encontraron en los meses de febrero y mayo y los menores en noviembre, variando desde 27.37 psu (noviembre) a 36.98 psu (mayo), con un valor medio de $35.38 \pm 1.64$ psu. Las concentraciones de oxígeno disuelto fueron altas ( $\geq 5 \mathrm{mg} / \mathrm{L}$ ) en Febrero y noviembre y los menores valores fueron en mayo, y generalmente se encontraron valores mayores en el lóbulo sur y menores en el norte. Dadas las características de esta espacie, la bahía de Cienfuegos cumple con los requisitos necesarios para la supervivencia y buen desarrollo de Perna viridis (33). 
Otra de las características más importantes de este sistema es el estado trófico de sus aguas. La eutrofización constituye uno de los procesos más importantes de deterioro de la calidad de las aguas costeras (121). Síntomas como altos niveles de clorofila- $a$, eventos de anoxia e hipoxia $(122,123)$ y florecimientos de algas tóxicas y nocivas $(124,125)$ son algunas de sus consecuencias. Seisdedo y Moreira del Centro de Estudios Ambientales de Cienfuegos (CEAC), en el 2007, clasificaron estas aguas como mesotróficas a ligeramente eutróficas en época poco lluviosa, y en época lluviosa, en ligeramente eutróficas a eutróficas, basándose en las concentraciones encontradas de fitoplancton. Dentro de los dinoflagelados encontraron como especie predominante a Prorocentrum micans, formadora de mareas rojas de toxicidad no demostrada y en pequeñas concentraciones que no afectaron la salud del ecosistema a las especies tóxicas: Prorocentrum minimun y Dinophysis caudata (28). Sin embargo Seisdedo y colaboradores en el 2009, mediante la aplicación de tres índices de clasificación del estado trófico de las aguas de la misma bahía no encontró predominio de niveles eutróficos, ni diferencias notables entre temporadas climáticas (29).

\section{I.5.1 CONTAMINACIÓN DE LA BAHÍA}

Los ecosistemas marinos son un resumidero de los contaminantes que ingresan y/o se generan en la columna de agua. Existe abundante evidencia sobre la acumulación de diversos tipos de contaminantes en el sedimento de las instalaciones portuarias y sus alrededores. (126, 127, 128, 129). Entre las bahías que reciben un mayor impacto antrópico en Cuba están las de La Habana, Cienfuegos, Puerto Padre, Guantánamo y Matanzas (130, 131, 132, 133).

En la Bahía de Cienfuegos las mayores afectaciones por contaminación se localizan fundamentalmente en el lóbulo septentrional (norte). Su origen se debe principalmente a la disposición final de efluentes industriales con un inadecuado tratamiento de depuración,

procedente de diversas empresas como: Refinería de Cienfuegos, Fábrica de Fertilizantes, Central Termoeléctrica, Azúcar a Granel y Empresa Pesquera Industrial (EPICIEN). A ello se adicionan los contaminantes procedentes de los ríos que desembocan en ella, los que incorporan a su cauce residuales industriales, albañales y agropecuarios; así como el vertimiento de hidrocarburos y de albañales procedentes del alcantarillado de la ciudad y de los buques del puerto. El resto de la bahía, en especial el lóbulo sur, presenta una calidad adecuada 
(26). La diferencia entre los lóbulos norte y sur puede estar relacionada con la capacidad de autodepuración de esta bahía, presentando tiempos de residencia de sus aguas de hasta 60 días para el norte, influenciado por su mayor volumen y el bajo "Las Cuevas", no así para el sur que solo requiere de 6 días por su menor volumen y cercanía al canal (27). Para supervisar y controlar las incidencias de las actividades que se realizan en este sistema y en su entorno, desde 1990 existe un Programa de Monitoreo Permanente de su Calidad Ambiental (PMPCA) dirigido por el Centro de Ingeniería y Manejo Ambiental de Bahías y Costas (CIMAB) (28).

Como parte de los residuales que incorpora este fuerte polo industrial, se encuentran los metales pesados. Estudios realizados en los últimos años corroboran la contaminación del sedimento por diferentes elementos como: Plomo $(\mathrm{Pb})$, Cobre $(\mathrm{Cu})$, Arsénico (As), Vanadio (V), entre otros (134). Una de las tareas desarrolladas por el PMPCA, es la utilización de diferentes macroalgas existentes en este acuatorio como biondicadoras de As, debido a la presencia de este metal por derrames accidentales y a la capacidad que tienen estos organismos de bioconcentrar estos tóxicos (135). Otros contaminantes de origen antropogénico reportados en los sedimentos de esta bahía son los hidrocarburos. Estudios realizados por investigadores del CIMAB, clasifican este ecosistema como ligeramente contaminado (2004) y contaminado (2006 y 2007), con valores que oscilan entre 61 y 1503 mg/Kg de masa seca de sedimento. (136, 137, 138). Por otra parte, Tolosa de la Agencia Internacional de Energía Atómica en colaboración con el CEAC en 2009, plantean que este ecosistema recibe anualmente alrededor de 52 t de hidrocarburos totales, principalmente en el lóbulo norte (31). En el 2010, a través de esta misma colaboración, se estudian otros compuestos orgánicos persistentes en sedimentos de esta bahía, donde encuentran plaguicidas como: Aldrín, DDT, Heptacloro, Hexaclobenceno y Lindano (32). 


\section{MATERIALES Y MÉTODOS}

\section{II.1 ÁREA DE ESTUDIO Y RED DE ESTACIONES}

El área de estudio fue la bahía de Cienfuegos, donde se estableció después de un estudio prospectivo, una red de estaciones con cinco puntos de muestreo: Muelle Pablo Guzmán (PG), Muelle Siete Cuadras (7C), Muelle Punta las Cuevas (PC), Barco Hundido (BH) y canales de enfriamiento de la Termoeléctrica (TE). La ubicación de estos puntos se muestra en la figura 2. La selección estuvo basada en las mayores densidades de Perna viridis.

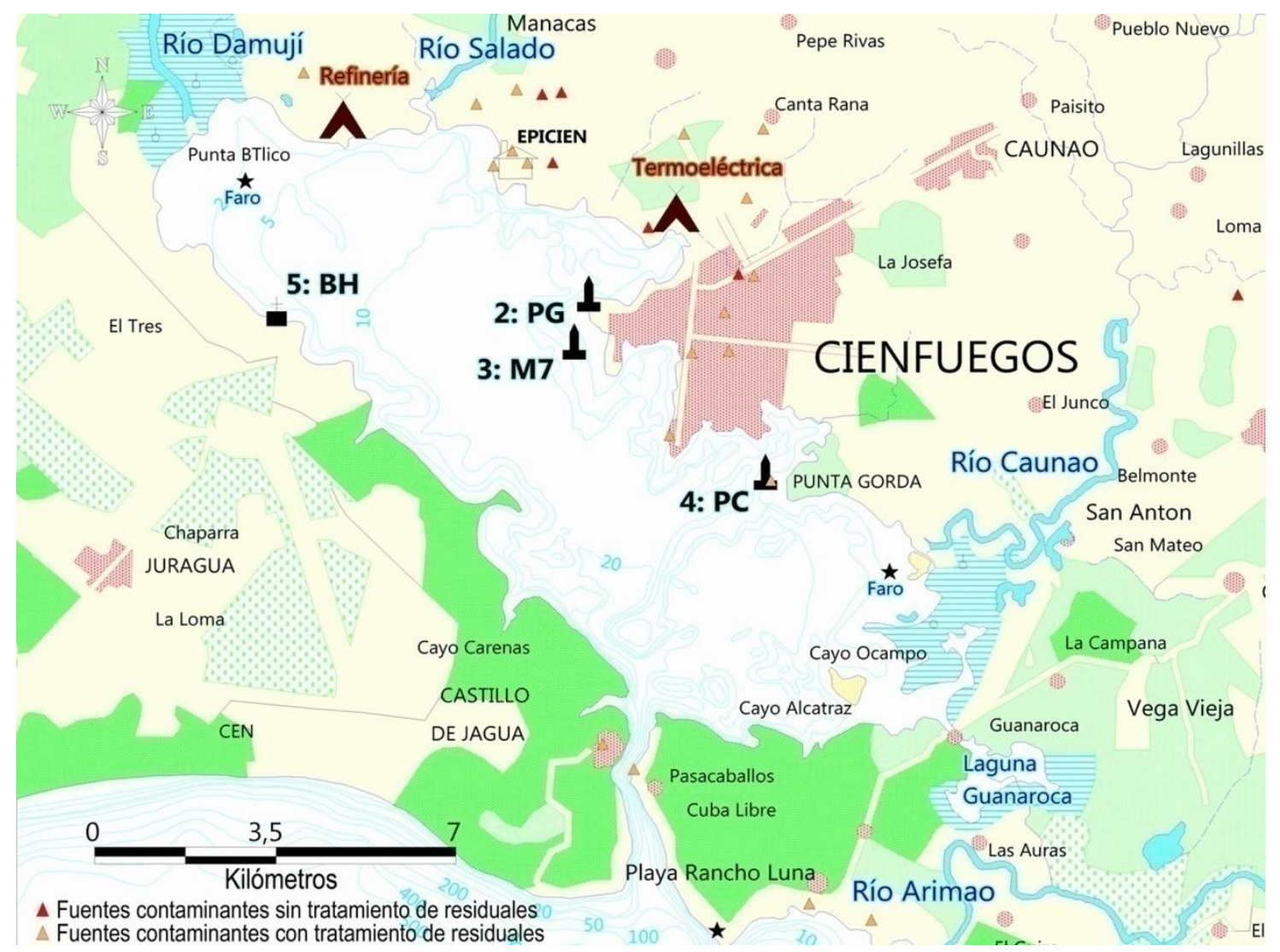

Figura 2. Estaciones de muestreo de ejemplares de mejillón verde (P.viridis) en la Bahía de Cienfuegos.

\section{2 TOMA DE MUESTRAS Y TRASLADO AL LABORATORIO}

Muestras de $P$. viridis mayores o iguales a $70 \mathrm{~mm}$ de largo antero posterior fueron colectadas del medio natural en los meses de septiembre, noviembre, diciembre del 2010 y en enero, febrero y mayo del 2011. Se tomaron alrededor de 200 ejemplares cada mes, que se utilizaron 
para realizar diferentes ensayos. Los mejillones fueron recogidos mediante buceo básico a profundidades de 1 a $2 \mathrm{~m}$. Los ejemplares fueron colocados en cajas plásticas perforadas donde se mantuvieron añadiéndoles agua de mar a intervalos de una hora hasta su desembarque. Posteriormente se trasladaron a la industria de la Empresa Pesquera Industrial Cienfuegos (EPICIEN) y se congelaron hasta alcanzar $-18^{\circ} \mathrm{C}$ en su centro térmico y se conservaron de esta manera hasta su análisis.

En el caso de los animales a los que se les realizó análisis microbiológico, estos se tomaron directamente del medio y se pasaron a bolsas plásticas selladas herméticamente. Se mantuvieron en hielo dentro de contenedores hasta su traslado al laboratorio antes de las $24 \mathrm{~h}$.

\section{II.3 BENEFICIO DE LOS MEJILLONES}

En el laboratorio, cada organismo se pesó y limpió cuidadosamente de adherencias y detritus en la concha y se le extrajo el biso, antes de la realizar los diferentes ensayos. Para los análisis microbiológicos estas operaciones se realizaron en condiciones de esterilidad y para la determinación de metales pesados la extracción de la carne se realizó con espátulas plásticas y/o porcelana.

\section{II.4 DETERMINACIÓN DE LA FRACCIÓN COMESTIBLE DE LA ESPECIE CON TALLA COMERCIAL}

Para la determinación de la fracción comestible de los mejillones verdes de talla comercial, se utilizaron 140 ejemplares, tomados al azar de los cinco puntos de muestreo. Cada individuo se pesó en balanza técnica (KERN 440-35N) con precisión de \pm 0.01 g y se determinó:

Peso total (PT): Peso de cada mejillón con su fauna acompañante adherida y el biso.

Peso total limpio (PTL): Peso de cada mejillón limpio de fauna acompañante, y sin biso (ver epígrafe 3).

Peso de masa fresca (MF): Cada mejillón fue abierto y se extrajo su masa incluyendo el músculo aductor, los que se pesaron.

La fracción comestible se calculó mediante los índices las siguientes relaciones: MF/PT y MF/PTL. 


\section{II.5 ESTIMACIÓN DE LA COMPOSICIÓN PROXIMAL DEL MEJILLÓN VERDE CRUDO Y COCIDO}

Para la determinación de la composición proximal de la masa fresca de los mejillones se tomaron 50 individuos al azar de los cinco puntos muestreados en la bahía, en el mes de noviembre. Se extrajo la masa, y se molió en máquina moledora, conformándose una muestra homogénea de aproximadamente $100 \mathrm{~g}$, para cada una de las determinaciones. Además se determinó la composición proximal de la masa cocinada en agua hirviendo por 3 minutos, para lo cual se tomó un pool de 30 mejillones y repitiéndose esta prueba por triplicado. Todas las determinaciones se realizaron por triplicado. Los análisis realizados fueron los siguientes:

Humedad: Se pesó $2 \pm 0.0001 \mathrm{~g}$ de masa fresca del mejillón en un crisol previamente seco y tarado, en balanza analítica (KERN 770). Se secó en estufa (BINDER) a $75^{\circ} \mathrm{C}$ las primeras $2 \mathrm{a}$ $3 \mathrm{~h}$ y a $105{ }^{\circ} \mathrm{C}$ durante 16 a $18 \mathrm{~h}$. La muestra se puso en desecadora y una vez atemperada se pesó en balanza analítica (KERN 770) hasta peso constante. El contenido de agua presente en la muestra, se calculó por la diferencia de pesada entre la muestra húmeda y seca y el valor obtenido se dividió entre el peso total y se multiplicó por cien. Según la norma: AOAC 950.468/00 (139).

Proteínas: Se pesó $1 \pm 0.0001 \mathrm{~g}$ de masa fresca sobre papel de filtro previamente tarado, en balanza analítica (KERN 770), se introdujo en tubo de digestión Kjeldahl y se añadió aproximadamente $5 \mathrm{~g}$ de la mezcla catalizadora $\left(\mathrm{K}_{2} \mathrm{SO}_{4}\right.$ y $\left.\mathrm{CuSO}_{4} 5 \mathrm{H}_{2} \mathrm{O}\right)$ y $20 \mathrm{~mL}$ de $\mathrm{H}_{2} \mathrm{SO}_{4}$ concentrado. Se digirió la muestra a $400{ }^{\circ} \mathrm{C}$, hasta coloración verde - azul en digestor (GERHARDT). Se trasvasó cuantitativamente lo digerido a un balón de destilación con 200 a $250 \mathrm{~mL}$ de agua, se adicionó $50 \mathrm{~mL}$ de $\mathrm{NaOH}$ (50\%) y se destiló en destilador (GERHARDT). Se recogió aproximadamente entre 150 - $200 \mathrm{~mL}$ de destilado en un recipiente que contenía 25 $\mathrm{mL}$ de $\mathrm{H}_{2} \mathrm{SO}_{4}(0.5 \mathrm{~N})$ e indicador rojo de metilo y se valoró por retroceso con $\mathrm{NaOH}(0.5 \mathrm{~N})$ hasta cambio de color de rosado a amarillo. Se calculó el contenido de nitrógeno por la fórmula:

$$
\% \text { Nitrógeno }=\frac{\left[\left(V_{1} N_{1}-V_{2} N_{2}\right)-\left(V_{1} N_{1}-V_{3} N_{2}\right)\right] \times 14 \times 100}{1000 \times P m}
$$


Donde:

$\mathrm{V}_{1}$ : Volumen $(\mathrm{mL})$ de la solución recibidora (ácido sulfúrico)

$\mathrm{V}_{2}$ : Volumen (mL) de hidróxido de sodio gastado en la valoración de la muestra

$\mathrm{V}_{3}$ : Volumen $(\mathrm{mL})$ de hidróxido de sodio gastado en la valoración del blanco

$\mathrm{N}_{1}$ : Normalidad del ácido sulfúrico

$\mathrm{N}_{2}$ : Normalidad del hidróxido de sodio

14: Peso equivalente del Nitrógeno

100: Factor para expresar el resultado en porciento

1000: Factor que convierte mili equivalentes en equivalentes

El por ciento de nitrógeno se multiplicó por el factor 6.25 para obtener el por ciento de proteínas en la muestra. El método Kjeldahl aplicado, se basó en las normas: AOAC 940.25/00 y AOAC 955.04/00 (140, 141).

Grasas: Se pesó de 2 a $3 \pm 0.0001 \mathrm{~g}$ de muestra de masa fresca en un beaker previamente tarado, en balanza analítica (KERN 770), se le añadió el doble en peso de sulfato de sodio anhidro y se homogenizó. Se trasvasó cuantitativamente a un dedal con la ayuda de un agitador de vidrio. Se limpió bien el beaker con el agitador y un algodón con éter de petróleo y se colocó taponando el dedal. Se procedió a la extracción de la materia grasa mediante lo sucesivos pasos del solvente orgánico por el dedal, empleando el equipo SOXHLET. Se desechó el dedal y se trasvasó cuantitativamente la grasa con el éter a un beaker previamente tarado. El solvente se evaporó a temperatura ambiente bajo campana. Se pesó hasta obtener masa constante en balanza analítica (KERN 770). El por ciento de grasa se calculó por la siguiente ecuación:

$$
\% \text { Grasa }=\frac{(a-b)}{m} \times 100
$$


Donde:

$\mathrm{a}=$ masa beaker + grasa $(\mathrm{g})$

$\mathrm{b}=$ masa beaker vacío $(\mathrm{g})$

$\mathrm{m}=$ masa porción de ensayo $(\mathrm{g})$

El método aplicado se basó en la norma: AOAC 920.39/00 (142).

Cenizas: Se procedió a pesar y secar la muestra de masa fresca según lo descrito para la determinación de humedad (139). Después se pasaron a la mufla (HORBERSAL HD-230) y se incineraron a $550{ }^{\circ} \mathrm{C}$ durante un tiempo aproximado de $3 \mathrm{~h}$, hasta obtener cenizas de color blanco. Se esperó que bajara la temperatura del equipo y se colocaron los crisoles en la desecadora. Se pesaron en balanza analítica (KERN 770) y se anotó el valor de la pesada. El por ciento de cenizas se calculó mediante la fórmula:

$$
\% \text { Cenizas }=\frac{(a-b)}{m} \times 100
$$

Donde:

$\mathrm{a}=$ masa crisol + muestra incinerada $(\mathrm{g})$

$\mathrm{b}=$ masa crisol vacío $(\mathrm{g})$

$\mathrm{m}=$ masa porción de ensayo sin incinerar $(\mathrm{g})$

La determinación de cenizas se basó en la norma, AOAC 938.08/00 (143).

Los hidratos de carbono se hallaron por diferencia $[100-$ (humedad + proteína + grasa + cenizas)], también se estimó el contenido calórico $(\mathrm{CC})$ a partir de la siguiente ecuación: $\mathrm{CC}=$ 9,02 x (\% lípidos totales $)+4,27 \times$ (\% proteína $)+4,27 \times$ (\% carbohidratos $).$

\section{II.6 ANÁLISIS MICROBIOLÓGICO DEL MEJILLÓN FRESCO}

Se tomaron 20 ejemplares de mejillón verde, diez en Pablo Guzmán e igual cantidad en Muelle Siete Cuadras, por presentar estos puntos la mayor abundancia de mejillones en la bahía. El 
muestreo se realizó de forma aleatoria simple en los meses junio, septiembre y noviembre de 2010 y febrero y noviembre de 2011.

\section{II.6.1 PREPARACIÓN DE LA MUESTRA DE ENSAYO}

Una vez en el laboratorio, las muestras se colocaron en bandeja de acero inoxidable, separadas por puntos de muestreo. Se abrieron las conchas con pinzas dentadas estériles para formar muestras homogéneas por cada grupo, de aproximadamente $75 \mathrm{~g}$ con carne y líquido intravalvar. A partir de esta mezcla, se pesaron en balanza técnica (KERN 440-35N) 22 g para las determinaciones; Microorganismos a $30{ }^{\circ} \mathrm{C}$, Enumeración de coliformes fecales, E. coli y Staphylococcus coagulasa ${ }^{+} ; 25$ g para las determinaciones de Vibrio parahaemolyticus y Vibrio cholerae y la misma cantidad para Salmonella spp.

\section{II.6.2 PREPARACIÓN DE LA SUSPENSIÓN INICIAL Y DE LAS DILUCIONES DECIMALES ADICIONALES}

La porción de ensayo de 22 g fue homogenizada en 198 mL de Solución Salina Peptonada (SSP) durante 3 min en homogenizador (STOMACHER LAB-BLENDER 400), para obtener la suspensión inicial 1:10. De la suspensión inicial se transfirió $1 \mathrm{~mL}$ a un tubo de cultivo que contenía $9 \mathrm{~mL}$ de SSP y así sucesivamente hasta obtener diluciones decimales seriadas adicionales hasta $10^{-3}$, según la metodología descrita en NC ISO 6887-1: 2003 (144). La porción de ensayo de $25 \mathrm{~g}$ para Vibrio fue homogenizada de igual forma pero en $225 \mathrm{~mL}$ de Agua de Peptona Alcalina (APA) y se incubó a $41.5 \pm 1{ }^{\circ} \mathrm{C}$ por $6 \pm 1 \mathrm{~h}$, según lo descrito en la NC ISO/TS 21872-1: 2007 (145). En el caso de Salmonella la porción se homogenizó en 225 $\mathrm{mL}$ de Agua de Peptona Bufferada (APB) y se incubó a $37 \pm 1{ }^{\circ} \mathrm{C}$ por $18 \pm 2$ h, según lo descrito en NC ISO 6887-1: 2003 (144).

Microorganismos a $30{ }^{\circ} \mathbf{C}$ : Se tomó $1 \mathrm{~mL}$ de la suspensión inicial y de las diluciones decimales seriadas, se inocularon a profundidad por duplicado en placas Petri estériles, las que fueron recubiertas con $15 \mathrm{~mL}$ de Agar para Conteo en placas. Las placas fueron invertidas e incubadas a $30 \pm 1{ }^{\circ} \mathrm{C}$ por $72 \pm 3 \mathrm{~h}$, en incubadora (TERMAKS). Luego de este tiempo se realizó el conteo de las colonias, con el contador de colonias (SUNTEX COLONY COUNTER 570), según NC ISO 4833: 2011 (146). 
Enumeración de coliformes fecales y $\boldsymbol{E}$. coli: A partir de la suspensión inicial, se utilizó medio líquido en tubos múltiples con la serie de tres tubos de cultivo, escogiendo los tubos fermentados en caldo Echerichia coli (EC), que fueron incubados a $44.5 \pm 1{ }^{\circ} \mathrm{C}$ por $48 \mathrm{~h}$ para los coliformes fecales y por 24 h para E.coli, según lo descrito en las normas cubanas (147, 148). En el caso de E. coli, los tubos fermentados en Caldo (EC) se confirmaron en agua de triptona para la prueba de Indol y se incubaron a $44.5 \pm 1{ }^{\circ} \mathrm{C}$ por $48 \pm 2 \mathrm{~h}$, siguiendo la metodología de la norma cubana (148). Al mismo tiempo, se aplicó otra vía de confirmación, donde se tomó $0.1 \mathrm{~mL}$ de cada uno de los tubos fermentados, se inoculó por diseminación en la superficie en placas Petri que contenían el medio CromoCen ${ }^{\circledR} \mathrm{CC}$ y se incubaron a $44.5 \pm 0.5$ ${ }^{\circ} \mathrm{C}$ durante $18 \pm 2 \mathrm{~h}$. Las colonias de E.coli en este medio se definieron con centros verdosos y con fluorescencia azul bajo luz ultravioleta $(366 \mathrm{~nm})$.

Staphylococcus coagulasa ${ }^{+}$: Se transfirió $0.1 \mathrm{~mL}$ de la suspensión inicial y de la dilución $10^{-2,}$ cada una por duplicado, a las superficies de placas que contenía Agar Baird Parker. Los inóculos fueron esparcidos con espátulas sobre el medio y se dejaron secar a temperatura ambiente. Las placas se invirtieron y fueron incubadas a $37 \pm 1^{\circ} \mathrm{C}$ por $24 \mathrm{~h}$ a $48 \mathrm{~h}$, en incubadora (TERMAKS). Luego se seleccionaron las colonias típicas o atípicas y se confirmaron mediante el ensayo de prueba de la coagulasa según lo descrito en NC ISO 68881: 2003 (149).

Vibrio parahaemolyticus y V. cholerae: De la suspensión inicial incubada, se tomó $1 \mathrm{~mL}$ a las $6 \pm 1 \mathrm{~h}$ y otro mililitro a las $18 \mathrm{~h}$ de un tubo de APA incubado a $41.5 \pm 1{ }^{\circ} \mathrm{C}$. Ambos fueron inoculados por estría en placas Petri con medios Tiosulfato Citrato Bilis Sacarosa (TCBS) y MacConkey. Las placas se incubaron a $37 \pm 1{ }^{\circ} \mathrm{C}$ por $24 \pm 3 \mathrm{~h}$. Se seleccionaron las colonias típicas para $V$. parahaemolyticus: redondas de 2 a $3 \mathrm{~mm}$ de diámetro, lisas, verdes-azules con centro verde y para $V$. cholerae: de igual forma y tamaño pero amarillas-pardas. Se realizaron las baterías de pruebas bioquímicas Todas las colonias seleccionadas fueron caracterizadas mediante los resultados de las pruebas bioquímicas y los cuadros bioquímicos correspondientes. En el caso de $V$. cholerae se continuó hasta la serología según los descrito en la norma ISO/TS 21872-1: 2007 (145). 
Salmonella spp: Pasado el tiempo de incubación de la suspensión inicial se tomó $1 \mathrm{~mL}$ y se transfirió a Caldo Rappaport-Vassiliadis con Soya y se incubó a $41.5 \pm 0.5{ }^{\circ} \mathrm{C}$ por $24 \pm 3 \mathrm{~h}$ y $0.1 \mathrm{~mL}$ a Caldo Muller-Kauffmann Tetrationato novabiocina y se incubó a $37 \pm 1{ }^{\circ} \mathrm{C}$ por $24 \pm 3$ h. De cada Caldo se tomó una asada y se sembraron por estría en placas Petri que contenían Agar Xilosa Lisina Desoxicolato (XLD) y Cromosen SC, se incubaron a $37 \pm 1{ }^{\circ} \mathrm{C}$ por $24 \pm 3 \mathrm{~h}$. Las colonias presuntivas se identificaron mediante pruebas bioquímicas y serológicas, según lo descrito en NC ISO 6579: 2008 (150).

\section{II.7 EVALUACIÓN DE DIFERENTES FORMAS DE PROCESAMIENTO MEDIANTE LA VARIACIÓN DE LOS TIEMPOS DE COCCIÓN}

Se ensayaron tres tiempos de cocción (2, 3 y 5 minutos) por inmersión en agua a $100^{\circ} \mathrm{C}$. Se determinó el rendimiento para cada tiempo de cocción (peso después de cocinado/peso fresco x 100), así como la temperatura alcanzada en el centro térmico de la masa del mejillón al final de la cocción, con un termómetro (THERMO MANAGER HDT-1). A todas las muestras se les determinaron además los indicadores microbiológicos de calidad que se refieren en el acápite 6.

\section{II.8 RENDIMIENTOS POST-COCCIÓN}

Un total de 52 mejillones previamente pesados fueron cocidos en agua a $100^{\circ} \mathrm{C}$ por 3 minutos. Transcurrido el tiempo de cocción, los mejillones se extrajeron del agua caliente, se drenaron y atemperaron, para realizar las siguientes determinaciones:

Peso Total limpio cocido (PTIC): Se colocó cada mejillón limpio, entero y cocido, igualmente en placa Petri previamente tarada y se anotó el valor de la pesada.

Peso de Media Concha con la masa cocida $\left(\mathrm{PMC}_{1 / 2}\right)$ : Cada mejillón limpio entero y cocido fue abierto y se retiró la concha que quedó libre de masa. La concha con masa, se colocó en placa Petri previamente tarada y se anotó el valor de la pesada.

Peso de $1 / 2$ Concha vacía $\left(\mathrm{PC}_{1 / 2}\right)$ : Cada concha que quedó libre de masa en el proceso anterior fue colocada en placa Petri previamente tarada y se anotó el valor de la pesada. 
Peso de las valvas limpias vacías (PV): Se retiró la masa cocida a cada concha. Se colocaron ambas conchas en placa Petri previamente tarada y se anotó el valor de la pesada. Se tuvo el cuidado de que las conchas vacías pertenecieran al mismo individuo.

Los parámetros analizados se utilizaron para estimar los rendimientos de las preparaciones: mejillones enteros cocidos y mejillones en media concha cocidos; con respecto al peso total y al peso total limpio.

\section{II.9 DETERMINACIÓN DE METALES PESADOS EN LA FRACCIÓN COMESTIBLE DEL MEJILLÓN VERDE}

Para los análisis de metales pesados se tomó la porción comestible de 20 ejemplares, de talla comercial por punto de muestreo. Las determinaciones se realizaron en los períodos de lluvia (mayo, 2011) y seca (noviembre, 2010), conformándose un pool con los ejemplares de todos los puntos por período.

La muestra se homogenizó por maceración en mortero de porcelana. Se pesó 10 g como porción de ensayo en crisoles de porcelana que se colocaron en estufa (BINDER) a $110{ }^{\circ} \mathrm{C}$ hasta secado. Las muestras fueron incineradas, con aumento progresivo de la temperatura hasta $550{ }^{\circ} \mathrm{C}$, en mufla (HORBERSAL HD-230) hasta obtención de cenizas blancas. Las cenizas fueron disueltas en ácido para ser utilizadas en los diferentes ensayos. En el caso de la determinación de mercurio las muestras se entregaron congeladas. Todas las determinaciones fueron realizadas en los laboratorios del Centro de Aplicaciones Tecnológicas y Desarrollo Nuclear (CEADEN).

Para la determinación de $\mathrm{Cd}$ y Pb se utilizó la técnica de Voltametría de Redisolución Anódica, según lo descrito en los procedimientos de este laboratorio (151), empleando para ello un Analizador Polarográfico tipo PA4. Este método puede interferir la presencia de materia orgánica y de oxígeno disuelto. Para resolver la primera interferencia, la muestra incinerada se disolvió con ácido fluorhídrico, perclórico y nítrico concentrado y para la segunda interferencia se hizo pasar por la solución una corriente de nitrógeno para desplazar el oxígeno.

Las determinaciones de $\mathrm{Fe}, \mathrm{Cu}$ y $\mathrm{Zn}$ se realizaron mediante Espectrofotometría de Absorción Atómica según lo descrito en el procedimiento (152), empleando un espectrofotómetro de 
absorción atómica (SP9-800 PYE UNICAM), previa disolución de la porción de ensayo con una mezcla de ácidos fluorhídrico, perclórico y nítrico concentrados.

La determinación de $\mathrm{Hg}$ se realizó mediante Espectrofotometría de Absorción Atómica, utilizando la técnica de vapor frío descrita en el procedimiento (153), empleando un espectrofotómetro de absorción atómica (SP9-800 PYE UNICAM). Este procedimiento incluye la conversión del mercurio en mercurio inorgánico divalente mediante un proceso de digestión ácida con reflujo.

\section{II.10 DETERMINACIÓN DE COMPUESTOS ORGÁNICOS PERSISTENTES EN MASA DE MEJILLÓN VERDE}

\section{II.10.1 Determinación de Hidrocarburos Aromáticos Policíclicos (HAPs)}

La muestra consistió en 50 especímenes tomados en el mes de junio en el Muelle Pablo Guzmán a los cuales se le extrajo su masa, la que fue homogenizada para obtener un pool, que se almacenó a $-20^{\circ} \mathrm{C}$ hasta su análisis. La determinación de HAPs se realizó en los laboratorios del Instituto de Nutrición e Higiene de los Alimentos (INHA).

La metodología analítica empleada para la determinación de los hidrocarburos aromáticos fue la descrita en la norma internacional (154), pesándose dos porciones de $10 \mathrm{~g}$ del pool, las cuales se trataron en Soxhlet con una mezcla de hexano/diclorometano durante 8 horas. Después de este tiempo, se realizó la saponificación con una mezcla KOH/Metanol y se extrajo con nhexano. La extracción obtenida se purificó en columnas con sílice y alúmina previamente tratadas y se eluyeron los analitos con una mezcla de hexano/diclorometano (1:1).

La mezcla del estándar analítico utilizada fue suministrada por la firma ULTRA SCIENTIFIC, conteniendo los siguientes hidrocarburos aromáticos: acenafteno, acenaftileno, antraceno, benzo(a)antraceno, benzo(a)pireno, benzo(b)fluoranteno, benzo(e)pireno, benzo(g,h,i)perileno, benzo(k)fluoranteno, bifenil, criseno, dibenzo(a,h)antraceno, dibenzotiofeno, fluoranteno, fluoreno, indeno(1,2,3-cd)pireno, naftaleno, 1-metil naftaleno, 2-metil naftaleno, 2,6-dimetil naftaleno, 2,3,5-trimetil naftaleno, perileno, fenantreno y 1-metil fenantreno, pireno.

Para los análisis de los HAPs se utilizó un cromatógrafo de gases (SHIMADZU2014) con una columna capilar BP5 (5 \% Phenyl y $95 \%$ dimethyl polysiloxane) de $30 \mathrm{~m} \mathrm{x} \mathrm{0,25} \mathrm{mm} \mathrm{de} \mathrm{DI} \mathrm{y}$ 
0,25 $\mu \mathrm{m}$ de espesor de película. La temperatura del inyector fue de $300{ }^{\circ} \mathrm{C}$, la temperatura del detector $320^{\circ} \mathrm{C}$ y un programa de temperatura para la columna con una temperatura inicial de $45^{\circ} \mathrm{C}$ durante 5 min, seguido de rampas de temperaturas hasta $310^{\circ} \mathrm{C}$.

Los resultados del contenido de cada uno de los HAPs presentes en ambas muestras fueron promediados y reportado para cada HAPs como los valores de contaminación presente en los mejillones en masa fresca.

\section{II.10.2 DETERMINACIÓN DE PALGUICIDAS ORGANOCLORADOS, POLICLOROBIFENILOS (PCBS) INDICADORES, DIOXINAS/FURANOS Y PCBS SIMILARES A DIOXINAS}

Para la determinación de Plaguicidas Organoclorados, Policlorobifenilos (PCBs) indicadores,

Dioxinas y Furanos y PCBs similares a Dioxinas, se tomó igualmente una muestra de 50 especímenes con los cuales se hizo un pool homogéneo de su masa previamente extraída, que fue liofilizado y enviado al laboratorio de referencia de la OMS en Freiburg, Alemania Chemisches und Veterinäruntersuchungsamt (CVUA), como parte del proyecto SAICM/UNEP "Creación de Capacidades para Laboratorios de COP en Cuba, bajo los Acuerdos Ambientales Multilaterales", donde fueron analizadas por Cromatografía gaseosa acoplada a masa (GC/MS).

La suma de PCDD/PCDFs incluyó a los siguientes congéneres:

PCDDs: $\quad 2,3,7,8$-TCDD $, \quad 1,2,3,7,8$-PeCDD $, \quad 1,2,3,4,7,8-\mathrm{HxCDD}, \quad 1,2,3,6,7,8-\mathrm{HxCDD}$, 1,2,3,7,8,9-HxCDD, 1,2,3,4,6,7,8-HpCDD y OCDD.

PCDFs: 2,3,7,8-TCDF; 1,2,3,7,8-PeCDF; 2,3,4,7,8-PeCDF; 1,2,3,4,7,8-HxCDF; 1,2,3,6,7,8HxCDF; 1,2,3,7,8,9-HxCDF; 2,3,4,6,7,8-HxCDF; 1,2,3,4,6,7,8-HpCDF; 1,2,3,4,7,8,9-HpCDF y OCDF.

La suma de los DL-PCBs incluyó a: PCB 77, PCB 81, PCB 126, PCB 169, PCB 105, PCB 114, PCB 118, PCB 123, PCB 156, PCB 157, PCB 167, PCB 189.

Los PCBs indicadores son: PCB 28, PCB 52, PCB 101, PCB 138, PCB 153, PCB 180. 
Los resultados de PCDD/PCDFs, DL-PCBs y PCBs reportados por el laboratorio CVUA en peso seco fueron llevados a peso fresco teniendo en cuenta un valor de humedad para el mejillón de $73 \%$, la cual fue previamente determinadas según el método anteriormente descrito (139).

\section{II.11 CÁLCULOS Y PROCESAMIENTO ESTADÍSTICO}

Los resultados se procesaron estadísticamente para estimar la media, desviación Standard, el coeficiente de variación, el intervalo de confianza y el rango de cada uno de los parámetros analizados. En el caso de los metales se realizó la prueba de $\mathrm{T}$ de student para conocer si existían diferencias significativas entre los periodos de lluvia y seca.

El procesamiento estadístico en su conjunto se realizó a través del software SigmaStat for Windows ${ }^{\circledR}$ versión 3.5, 2006. 


\section{RESULTADOS Y DISCUSIÓN}

\section{III.1 FRACCIÓN COMESTIBLE DE LA ESPECIE PARA TALLAS COMERCIALES}

El rendimiento de masa fresca respecto al peso total (PT) y al peso total limpio (PTL) para el grupo de tallas comerciales, se muestran en la Tabla 1.

Tabla 1. Resumen estadístico de la fracción comestible calculada como porcentaje de masa fresca respecto al PT y al PTL para tallas comerciales.

\begin{tabular}{|l|c|c|}
\hline \multirow{2}{*}{ Variables } & \multicolumn{2}{|c|}{ Tallas comerciales } \\
\cline { 2 - 3 } & $\mathrm{PT}$ & $\mathrm{PTL}$ \\
\hline Recuento & 140 & 140 \\
\hline Fracción comestible & $22,82 \%$ & $31,83 \%$ \\
\hline Desviación Estándar & 5,22 & 2,74 \\
\hline Coeficiente de Variación & $22,87 \%$ & $8,60 \%$ \\
\hline Mínimo & 12,68 & 26,11 \\
\hline Máximo & 32,64 & 37,95 \\
\hline Rango & 19,96 & 11,84 \\
\hline Intervalo de Confianza & $22,82 \pm 1.24$ & $31,83 \pm 0,65$ \\
\hline
\end{tabular}

El porcentaje de masa fresca en los mejillones de tallas mayores o iguales a $7 \mathrm{~cm}$ respecto al PT fue de $22.82 \%$, con un Intervalo de Confianza de $22.82 \pm 1.24$, en tanto estos valores respecto al PTL fueron del $31.83 \%$, con un Intervalo de Confianza de $31.83 \pm 0.65$. El rendimiento de masa fresca obtenido para $P$. viridis en este estudio, resultó mucho más alto, al de otros bivalvos procesados en nuestro país como; el ostión de mangle (Crassostrea rizophorae) 4,8 \% y la almeja (Arca zebra) $12 \%$ (155) e igualmente mayores a los reportados para la talla comercial del ostión Crassostrea rizophorae (10 \% - $13.5 \%$ ) cultivado en Brasil (156).

No obstante, el análisis del rendimiento de masa fresca de P.viridis cultivado a fondo, en el estado Sucre, Venezuela; mostró valores entre $31 \%$ y $48 \%$, en los meses de mayor índice de 
condición y menor esfuerzo reproductivo. Donde se observó una relación directa entre el contenido de masa comestible y el esfuerzo reproductivo e indirecta con el índice de condición (157). Por tanto nuestros altos valores de rendimientos de masa pueden estar relacionados igualmente con los periodos de menor actividad reproductiva y mayores índices de condición, por lo que la determinación del periodo de máxima reproducción de la especie en nuestro país será de vital importancia para lograr los máximos incrementos productivos y eficiencia económica en la explotación de este recurso pesquero.

\section{III.2 COMPOSICIÓN PROXIMAL DEL MEJILLÓN VERDE CRUDO Y COCIDO}

En la Tabla 2, se muestran los resultados de la composición proximal de la masa cruda y cocida del mejillón verde.

Tabla 2. Composición proximal de los mejillones crudos y cocidos.

\begin{tabular}{|l|c|c|c|c|c|c|}
\hline Mejillones & $\begin{array}{c}\text { Humedad } \\
(\mathrm{g} / 100 \mathrm{~g})\end{array}$ & $\begin{array}{c}\text { Proteína } \\
(\mathrm{g} / 100 \mathrm{~g})\end{array}$ & $\begin{array}{c}\text { Lípidos } \\
(\mathrm{g} / 100 \mathrm{~g})\end{array}$ & $\begin{array}{c}\text { Cenizas } \\
(\mathrm{g} / 100 \mathrm{~g})\end{array}$ & $\begin{array}{c}\text { Hidratos de } \\
\text { Carbono } \\
(\mathrm{g} / 100 \mathrm{~g})\end{array}$ & $\begin{array}{c}\text { Energía } \\
(\mathrm{Kcal} / 100 \mathrm{~g})\end{array}$ \\
\hline Crudos & $76.47-78.02$ & $11.83-12.25$ & $4.12-4.42$ & $1.79-2.23$ & $5.79-3.08$ & $101.1-107.6$ \\
\hline Cocidos & $73.69-73.89$ & $19.21-19.70$ & $2.60-3.39$ & $2.46-3.02$ & $2.04-0.0$ & $101.4-110.1$ \\
\hline
\end{tabular}

El componente más abundante en el músculo fresco de Perna viridis resultó la humedad, cuyo valor osciló entre $76.47 \%$ - 78.02 \%, luego las proteínas con valores entre $11.83 \%$ - 12.25\%. El rango de valores del contenido de proteínas de este estudio, fueron similares a los reportados por varios autores para Perna perna, de $12.5 \%$ (158) y $11.2 \%$ - $15.7 \%$ por Benítez y Okuda (159); en tanto Cabello reportó un rango de $12.14 \pm 1.57 \%$ de proteínas para $P$. viridis (24). El contenido de lípidos osciló entre $4.12-4.42 \%$, valores algo superiores a los reportados para $P$. perna por Benítez y Okuda $(0.6 \%$ - $3.5 \%)$ (159) y Lauro $2.43 \%$ (160) y para $P$. viridis por Cabello (2.11 $\pm 0.49 \%)(24)$. Mientras que en un estudio realizado en $P$. viridis de siete localidades del oriente venezolano y la costa oeste de Trinidad se encontraron valores entre 6.8 $\%-7.9 \%$ (64), superiores a los encontrados en este estudio. Las diferencias encontradas en los diferentes estudios deben estar relacionadas al período del año en que se realizan estos análisis, ya que el aumento de lípidos y proteínas en la masa de esta especie tiene lugar cuando los 
mejillones están próximos al desove y en plena madurez sexual $(42,64,157)$ y con la cantidad y calidad del alimento disponible (157) en el medio en que crecen.

Si comparamos los valores de composición proximal de esta especie foránea obtenidos en este estudio, con los valores de moluscos bivalvos, ampliamente estudiados y procesados industrialmente en Cuba, como el ostión de mangle (Crassostrea rizophorae) $(7.8 \pm 0.68 \%$ proteínas, $0.60 \pm 0.26 \%$ lípidos, $42.65 \pm 1.8 \mathrm{Kcal} / 100 \mathrm{~g}$ ) (161); podemos observar que no sólo presenta mayor rendimiento en masa como se ha planteado anteriormente, sino también valores superiores en cuanto a proteínas, lípidos y energía.

En el caso de la composición proximal de la masa cocida, podemos observar un ligero descenso de la humedad, por la pérdida de agua de los tejidos durante la cocción. Esto se debe fundamentalmente a la disminución de la capacidad de retención de agua de las proteínas debido a la coagulación de estas, lo cual ha sido reportado igualmente por diversos autores para otras especies $(162,163)$. De igual modo ocurre con el resto de los otros componentes (lípidos y minerales) en la carne cocinada del mejillón, en la que se observó un incremento de estos por la pérdida de humedad en la masa.

Como se observa en la Tabla 2 el contenido energético de la masa del mejillón tanto fresco como cocido presentó un valor relativamente bajo, aunque al comparar estos resultados con los de otros autores para mejillones de esta familia (23) fue ligeramente superior; pues el contenido calórico en estas especies está determinado principalmente por el contenido en lípidos, que en nuestro caso fue más elevado como se ha discutido con anterioridad.

De forma general 100 gramos de mejillón verde cocido, contribuiría en un $27 \%$ al total de los requerimientos de proteínas de las recomendaciones nutricionales ponderadas para la población cubana y en un $4.5 \%$ al total de energía (164). 


\section{III.3 CALIDAD MICROBIOLÓGICA DEL MEJILLÓN FRESCO}

En las Tablas 3 y 4 se pueden observar los resultados de los análisis microbiológicos realizados a los mejillones frescos durante el 2010 y 2011. En ninguna de las muestras estudiadas se verificó la presencia de Vibrio parahaemolyticus, Vibrio cholerae ni Staphylococcus coagulasa $^{+}$. Asimismo puede observarse que todos los conteos de microorganismos a $30{ }^{\circ} \mathrm{C}$ fueron bajos, teniendo en cuenta que el límite superior permitido para el consumo humano de la mayoría de los productos pesqueros es de $10^{5}$ ufc de m.o / g (165).

Tabla 3. Resultados de los análisis microbiológicos a P. viridis durante el 2010.

\begin{tabular}{|c|c|c|c|c|c|c|c|}
\hline \multirow{3}{*}{ Análisis } & \multirow{3}{*}{$\begin{array}{l}\text { Índices de } \\
\text { referencia }\end{array}$} & \multicolumn{6}{|c|}{ Zonas/meses 2010} \\
\hline & & \multicolumn{2}{|c|}{ Junio } & \multicolumn{2}{|c|}{ Septiembre } & \multicolumn{2}{|c|}{ Noviembre } \\
\hline & & PG & M7 & PG & M7 & PG & M7 \\
\hline $\begin{array}{l}\text { Salmonella spp. } \\
\text { (Ausencia en } 25 \mathrm{~g} \text { ) }\end{array}$ & $\begin{array}{c}m=0 \\
n=5 c=0\end{array}$ & Ausencia & Ausencia & Presencia & Presencia & Ausencia & Ausencia \\
\hline $\begin{array}{l}\text { Vibrio } \\
\text { parahaemolyticus } \\
\text { (ufc/g) }\end{array}$ & $\begin{array}{c}m=10^{2} \\
n=5 c=0\end{array}$ & $<10^{2}$ & $<10^{2}$ & $<10^{2}$ & $\ll 10^{2}$ & $<10^{2}$ & $<10^{2}$ \\
\hline $\begin{array}{l}\text { Vibrio cholerae } \\
\text { (Ausencia en } 25 \mathrm{~g} \text { ) }\end{array}$ & $\begin{array}{c}\mathrm{m}=0 \\
\mathrm{n}=5 \mathrm{c}=0\end{array}$ & Ausencia & Ausencia & Ausencia & Ausencia & Ausencia & Ausencia \\
\hline $\begin{array}{l}\text { Enumeración de } \\
\text { microorganismos a } \\
30{ }^{\circ} \mathrm{C} \text { (ufc/g) }\end{array}$ & $\begin{array}{l}10^{4}-10^{5} \\
n=5 c=2\end{array}$ & $1,7 \times 10^{2}$ & $2,1 \times 10^{3}$ & $1,4 \times 10^{3}$ & $2,2 \times 10^{2}$ & $3,3 \times 10^{2}$ & $2,6 \times 10^{2}$ \\
\hline $\begin{array}{l}\text { Staphylococcus } \\
\text { coagulasa }^{+}(\mathrm{ufc} / \mathrm{g})\end{array}$ & $\begin{array}{l}10^{2}-10^{3} \\
\mathrm{n}=5 \mathrm{c}=2\end{array}$ & $<10^{2}$ & $<10^{2}$ & $\ll 10^{2}$ & $\ll 10^{2}$ & $<10^{2}$ & $\ll 10^{2}$ \\
\hline $\begin{array}{l}\text { Coliformes } \\
\text { termotolerantes } \\
\text { (NMP/100g) }\end{array}$ & $\begin{array}{c}230-700 \\
n=5 c=2\end{array}$ & 360 & 280 & 1500 & 4600 & 230 & 40 \\
\hline $\begin{array}{l}\text { E.coli } \\
\text { (NMP/100g) }\end{array}$ & $\begin{array}{c}\mathrm{m}<230 \\
\mathrm{n}=5 \mathrm{c}=0\end{array}$ & 40 & 90 & 300 & 1200 & 30 & 40 \\
\hline
\end{tabular}


Tabla 4. Resultados de los análisis microbiológicos a $P$. viridis durante el 2011

\begin{tabular}{|c|c|c|c|c|c|}
\hline \multirow{3}{*}{ Análisis } & \multirow{3}{*}{$\begin{array}{l}\text { Índices de } \\
\text { referencia }\end{array}$} & \multicolumn{4}{|c|}{ Zonas/meses 2011} \\
\hline & & \multicolumn{2}{|c|}{ Febrero } & \multicolumn{2}{|c|}{ Noviembre } \\
\hline & & PG & M7 & PG & M7 \\
\hline $\begin{array}{l}\text { Salmonella spp. } \\
\text { (Ausencia en } 25 \text { g) }\end{array}$ & $\underset{c=0}{m=0} \mathrm{n}=5$ & Ausencia & Ausencia & Ausencia & Ausencia \\
\hline $\begin{array}{l}\text { Vibrio parahaemolyticus } \\
\text { (ufc/g) }\end{array}$ & $\begin{array}{c}\mathrm{m}=10^{2} \\
\mathrm{n}=5 \mathrm{c}=0\end{array}$ & $<10^{2}$ & $<10^{2}$ & $<10^{2}$ & $<10^{2}$ \\
\hline $\begin{array}{l}\text { Vibrio cholerae } \\
\text { (Ausencia en } 25 \mathrm{~g} \text { ) }\end{array}$ & $\begin{array}{c}\mathrm{m}=0 \quad \mathrm{n}=5 \\
\mathrm{c}=0\end{array}$ & Ausencia & Ausencia & Ausencia & Ausencia \\
\hline $\begin{array}{l}\text { Enumeración de } \\
\text { microorganismos a } 30{ }^{\circ} \mathrm{C}(\mathrm{ufc} / \mathrm{g})\end{array}$ & $\begin{array}{c}10^{4}-10^{5} \\
n=5 c=2\end{array}$ & $5,4 \times 10$ & $5,1 \times 10^{3}$ & $2,0 \times 10^{3}$ & $3.2 \times 10^{2}$ \\
\hline $\begin{array}{l}\text { Staphylococcus coagulasa+ } \\
\text { (ufc/g) }\end{array}$ & $\begin{array}{l}10^{2}-10^{3} \\
n=5 c=2\end{array}$ & $<10^{2}$ & $<10^{2}$ & $<10^{2}$ & $<10^{2}$ \\
\hline $\begin{array}{l}\text { Coliformes fecales } \\
(\mathrm{NMP} / 100 \mathrm{~g})\end{array}$ & $\begin{array}{c}230-700 \\
n=5 c=2\end{array}$ & 70 & 90 & 680 & $<18$ \\
\hline $\begin{array}{l}\text { E. coli } \\
(\mathrm{NMP} / 100 \mathrm{~g})\end{array}$ & $\begin{array}{c}\mathrm{m}<230 \\
\mathrm{n}=5 \mathrm{c}=0\end{array}$ & 70 & 40 & $<18$ & $<18$ \\
\hline
\end{tabular}

Sin embargo, en Septiembre de 2010, para ambas zonas de muestreo la concentración de coliformes fecales (termotolerantes) y de E. coli, excedieron el límite establecido en la norma Codex para los moluscos bivalvos vivos y los moluscos bivalvos crudos (25), de 700 NMP/100 g y 230 NMP/100 g respectivamente para carne y líquido intravalvar. No obstante, si el recuento sobrepasa estos límites la Comunidad Europea permite su comercialización con previa depuración $(166,167)$.

Los coliformes fecales usualmente se ubican en aguas y alimentos contaminados con heces fecales y frecuentemente están asociadas con los brotes de enfermedades trasmitidas por alimentos (14). El hallazgo de bacterias pertenecientes a este grupo es significativo, pues aunque estos normalmente no son patógenos por sí mismos, como E. aerogenes que es de origen extraintestinal, su existencia indica la posible presencia de microorganismos patógenos como Salmonella. De igual forma la presencia de E.coli en los mejillones también indica contaminación fecal, lo que implica el rechazo del producto.

En Septiembre de 2010, se comprobó la presencia de una cepa de Salmonella Cholerae-suis con un acelerado metabolismo microbiano, en las muestras analizadas en ambos sitios. Las cepas de 
Salmonella constituyen una de las principales causas de intoxicación alimentaria de origen animal en el mundo entero. Salmonella Cholerae-suis produce gastroenteritis con cuadros septicémicos con bacteriemia en el Sistema Nervioso Central, hueso, pulmón y riñón, y los pacientes infectados pueden excretarla por semanas o meses después de curados. Por tanto, la fuente más frecuente de infección es la ingestión de alimentos y aguas contaminadas, y el control de la enfermedad se basa en las medidas higiénico-sanitarias, así como en el control de los alimentos tanto de los humanos como de aquellos suministrados a aves u otros animales de consumo por el hombre (168). Teniendo en cuenta todo esto, pudiéramos decir que los ejemplares colectados en ese momento no estuvieron aptos para el consumo humano, según las especificaciones sanitarias establecidas por la norma cubana de contaminantes microbiológicos para el consumo de productos pesqueros (165). Sin embargo, en el resto del período de estudio, no volvieron a aparecer cepas de Salmonella. Esto pudiera estar relacionado con el comportamiento de las aguas residuales vertidas a la bahía en dependencia de la época del año $(169,170,171)$. Como se observa en la figura 3 el mayor acumulado de lluvia en la ciudad de Cienfuegos para el período de enero 2010 a noviembre de 2011, ocurrió en septiembre de 2010. El análisis microbiológico correspondiente, mostró tanto una cepa de Salmonella que no apareció más en todo el estudio, como el aumento del resto de los indicadores que sobrepasaron lo establecido para el consumo humano, en la norma cubana (165).

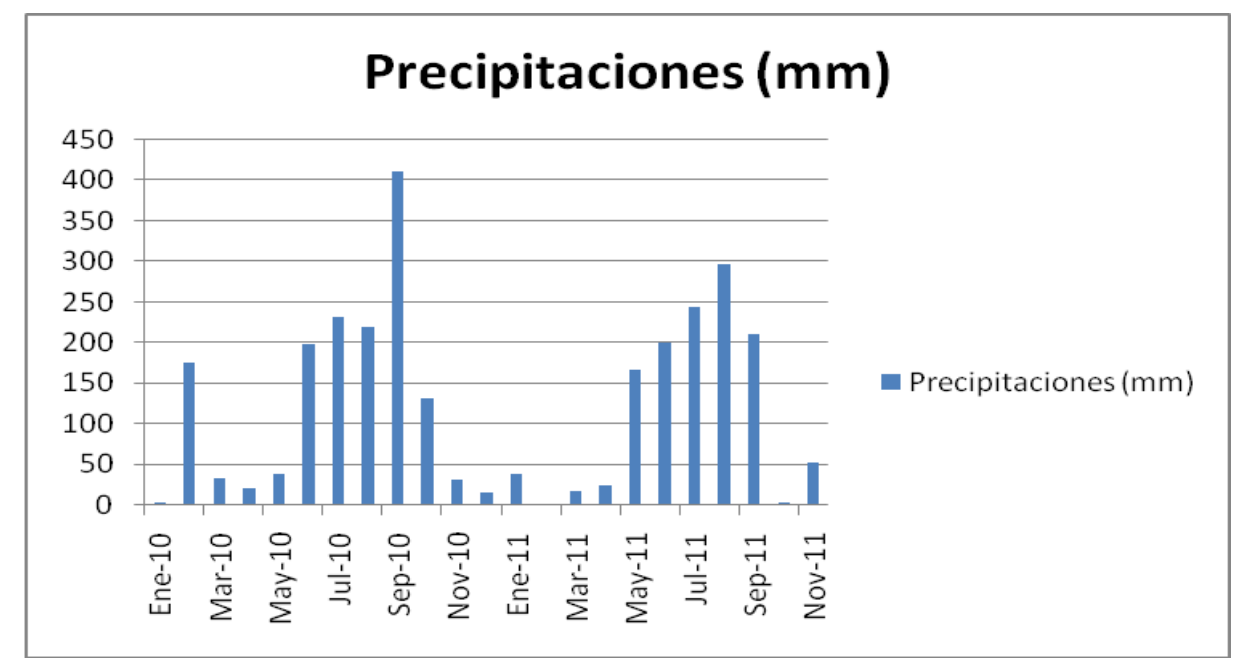

Figura 3. Acumulados mensuales de precipitacines para la ciudad de Cienfuegos desde enero de 2010 a noviembre de 2011 (Datos obtenidos a partir de la estación meteorológica de la ciudad de Cienfuegos). 
Estos resultados se correlacionan con los encontrados al analizar la calidad sanitaria del agua, si tenemos en cuenta el carácter filtrador de $P$. viridis, y el hecho de que los mayores índices de contaminación con coliformes fecales se encontraron en el agua, en Septiembre de 2010. En el año 2011, los resultados microbiológicos obtenidos en el producto durante los meses de Enero, Febrero y Noviembre cumplieron con las especificaciones microbiológicas establecidas para los moluscos bivalvos crudos.

\section{III.4 RESULTADOS DE LOS TRATAMIENTOS DE COCCIÓN}

Los resultados del estudio de calidad microbiológica post tratamiento térmico mostraron que los tres tratamientos fueron efectivos, disminuyendo los conteos de mesófilos, coliformes fecales y E. coli presentes en las muestras, así como la eliminación de la cepa de Salmonella.spp encontrada en una de las muestras analizadas. Estos resultados nos indicaron que los tratamientos de cocción aplicados permitieron obtener productos que cumplieron con los parámetros microbiológicos establecidos para el consumo humano de productos pesqueros congelados (165), y con los requisitos de la FDA para moluscos congelados (172).

La temperatura en el Centro Térmico (CT) del mejillón y los rendimientos alcanzados para cada uno de los tiempos de cocción aplicados, se muestran en la Tabla 5.

Tabla 5. Temperatura del Centro térmico (CT) y Rendimiento para los tres tiempos de cocción ensayados.

\begin{tabular}{|l|c|c|c|}
\hline \multirow{2}{*}{ Parámetros analizados } & \multicolumn{3}{|c|}{ Tiempos de cocción a $\mathbf{1 0 0}{ }^{\circ} \mathbf{C}$} \\
\cline { 2 - 4 } & $5 \mathrm{~min}$. & $3 \mathrm{~min}$. & $2 \mathrm{~min}$ \\
\hline Temp. CT $\left({ }^{\circ} \mathrm{C}\right)$ & 94 & 94 & 91 \\
\hline Rendimiento $(\%)$ & 77.2 & 79.8 & 80.9 \\
\hline
\end{tabular}

Como se observa, la temperatura más baja en el CT del mejillón se alcanzó, como era de esperar con 2 minutos de cocción. Para este mismo tiempo de cocción se detectó la presencia de Aeromonas sp, Vibrio sp y Bacillus sp, lo que indicó que la cocción no fue lo suficientemente efectiva, ya que las cepas de los géneros Aeromonas y Vibrio son poco resistentes a las altas temperaturas. A pesar de que la temperatura en el centro térmico sobrepasa los $75^{\circ} \mathrm{C}$, el tiempo que esta se mantiene no es suficiente para eliminar los microorganismos más resistentes como los Bacillus sp. $(173,174)$. 
Teniendo en cuenta los resultados anteriores se determinó establecer un tiempo de 3 minutos a $100{ }^{\circ} \mathrm{C}$ como el indicado para la cocción, ya que logra un cocido eficiente en cuanto a la calidad microbiológica y los más altos rendimientos. Los resultados del estudio de calidad microbiológica de las dos muestras (3 y 5 minutos de cocción) permitieron concluir que ambos tiempos fueron efectivos, como se muestra en la Tabla 6, ya que disminuyeron los conteos de mesófilos y de coliformes fecales y además, se eliminaron las células de E. coli presentes en la muestra fresca (Tabla 6).

Tabla 6. Resultados del análisis microbiológico para determinar la efectividad de los tratamientos de cocción.

\begin{tabular}{|c|c|c|c|c|}
\hline \multirow{2}{*}{ Análisis } & \multirow{2}{*}{$\begin{array}{l}\text { Índices de } \\
\text { referencia }\end{array}$} & \multicolumn{3}{|c|}{ Muestras } \\
\hline & & Cruda & Cocida 3 min. & Cocida $5 \mathrm{~min}$. \\
\hline Salmonella.spp & $\begin{array}{c}\mathrm{m}=0 \quad \mathrm{n}=5 \mathrm{c}=0 \\
\text { Ausencia en } 25 \mathrm{~g}\end{array}$ & negativo & negativo & negativo \\
\hline $\begin{array}{l}\text { Vibrio } \\
\text { parahaemolyticus }\end{array}$ & $\mathrm{m}=10^{2} \quad \mathrm{n}=5 \mathrm{c}=0$ & $<10^{2}$ & $<10^{2}$ & $<10^{2}$ \\
\hline Vibrio cholerae & $\begin{array}{c}\mathrm{m}=0 \quad \mathrm{n}=5 \mathrm{c}=0 \\
\text { Ausencia }\end{array}$ & negativo & negativo & negativo \\
\hline $\begin{array}{l}\text { Conteo total de } \\
\text { mesófilos }(\mathrm{m} . \mathrm{o} / \mathrm{g})\end{array}$ & $10^{4}-10^{5} \quad \mathrm{n}=5 \mathrm{c}=2$ & $5.4 \times 10^{2}$ & $3.6 \times 10$ & $2.6 \times 10^{2}$ \\
\hline $\begin{array}{l}\text { Staphylococcus } \\
\text { coagulasa }^{+} \\
(\mathrm{m} . \mathrm{o} / \mathrm{g})\end{array}$ & $10^{2}-10^{3} \quad n=5 \mathrm{c}=2$ & $<10^{2}$ & $<10^{2}$ & $<10^{2}$ \\
\hline $\begin{array}{l}\text { Coliformes } \\
\text { fecales (NMP/g) }\end{array}$ & $0,3-2,1 \mathrm{n}=5 \mathrm{c}=2$ & 0.7 & $<0.3$ & $<0.3$ \\
\hline E. coli $(\mathrm{NMP} / \mathrm{g})$ & $\begin{array}{c}\mathrm{m}<0,3 \quad \mathrm{n}=5 \mathrm{c}=0 \\
\text { Ausencia }\end{array}$ & 0.7 & $<0.3$ & $<0.3$ \\
\hline
\end{tabular}

Los rendimientos de $P$. viridis cocidos, enteros y en media concha, durante 5 y 3 minutos a 100 ${ }^{\circ} \mathrm{C}$, en las tallas comerciales (mayores de $7 \mathrm{~cm}$ ), con respecto al PT y PL, se muestra en la Tabla 7. 
Tabla 7. Resumen estadístico obtenido de los rendimientos después de la cocción de $P$. viridis con tallas comerciales, respecto al peso total (PT) y al peso limpio (PL).

\begin{tabular}{|l|c|c|c|c|c|c|c|c|}
\cline { 2 - 10 } \multicolumn{1}{c|}{} & \multicolumn{7}{|c|}{ Tiempos de cocción } \\
\cline { 2 - 10 } \multicolumn{1}{c|}{} & \multicolumn{3}{|c|}{5 minutos } & \multicolumn{4}{c|}{ 3 minutos } \\
\hline \multirow{2}{*}{ Estadígrafos } & \multicolumn{2}{|c|}{ Entero } & \multicolumn{2}{c|}{ Media Concha } & \multicolumn{2}{c|}{ Entero } & Media Concha \\
\cline { 2 - 10 } & PT & PL & PT & PL & PT & PL & PT & PL \\
\hline Recuento & 52 & 52 & 52 & 52 & 52 & 52 & 52 & 52 \\
\hline Promedio & $54,46 \%$ & $81,51 \%$ & $30,92 \%$ & $46,67 \%$ & $57,66 \%$ & $84,31 \%$ & $33,82 \%$ & $49,57 \%$ \\
\hline Desv. Estd. & 7,44 & 7,11 & 6,19 & 6,98 & 7,47 & 7,31 & 6,89 & 6.18 \\
\hline Coef de Var & $13,67 \%$ & $8,7 \%$ & $20,02 \%$ & $14,96 \%$ & $12,24 \%$ & $9,7 \%$ & $5,89 \%$ & $5,56 \%$ \\
\hline Mínimo & 41,84 & 66,5 & 19,97 & 34,63 & 44,15 & 47,90 & 20,01 & 35,33 \\
\hline Máximo & 71,26 & 93,17 & 44,31 & 56,44 & 73,24 & 74,15 & 43,90 & 57,71 \\
\hline Rango & 29,42 & 26,67 & 24,34 & 21,81 & 29,09 & 26,25 & 23,89 & 22,83 \\
\hline Interv. Conf. & $54,46 \pm$ & $81,51 \pm$ & $30,92 \pm$ & $46,67 \pm$ & $57,6 \pm$ & $84,31 \pm$ & $33,82 \pm$ & $49,57 \pm$ \\
& 3,30 & 3,33 & 2,74 & 3,09 & 2,74 & 2,8 & 2,56 & 2,13 \\
\hline
\end{tabular}

El rendimiento promedio del mejillón cocido por 5 minutos fue del $54.46 \%$ respecto al PT y del $81.58 \%$ respecto al PL, en tanto los rendimientos alcanzados para el cocido por 3 minutos, fue aproximadamente de un $3 \%$ mayor. Para la masa cocida por 5 minutos en media concha el rendimiento promedio fue del $30.92 \%$ respecto al PT y del $46.67 \%$ respecto al PL, sin embargo igualmente los valores más altos de rendimiento resultaron para la variante cocida por tres minutos. Los más altos rendimiento obtenidos para las muestras cocinadas por tres minutos son un firme argumento para establecer el tiempo de procesamiento de esta especie en el futuro en la industria y más si tenemos en cuenta que con él se alcanza una inocuidad microbiológica. Es necesario señalar que actualmente el MINAL importa unas $30 \mathrm{~T}$ de masa cocida e igual cantidad de media concha cocida congelada para satisfacer las demandas del mercado interno en divisas (175). 


\section{III.5 METALES PESADOS DE LA FRACCIÓN COMESTIBLE DE MEJILLONES CON TALLA COMERCIAL}

El análisis de los metales pesados en el mejillón verde de la bahía de Cienfuegos mostró que los metales esenciales $(\mathrm{Fe}, \mathrm{Zn} \mathrm{y} \mathrm{Cu}$ ), se encontraron en mayor proporción que los eminentemente tóxicos ( $\mathrm{Pb}, \mathrm{Cd}$ y $\mathrm{Hg}$ ), en los dos períodos estudiados (Tablas 8 y 9), lo cual es normal si se tiene en cuenta la doble funcionalidad de los primeros. Los metales esenciales o microelemenmtos ( $\mathrm{Fe}, \mathrm{Zn}$ y $\mathrm{Cu}$ ) son cofactores de numerosas enzimas necesarias para el buen desarrollo del molusco, por tanto se encuentran en mayor cuantía en dependencia de los requerimientos metabólicos del organismo para mantener su tasa de crecimiento, reproducción y desove $(9,10)$. Esto coincide en el caso del Cobre y el Zinc con lo expresado por Usero y colaboradores, que plantean que ambos elementos en pequeñas cantidades, actúan como componentes estructurales o catalíticos indispensables para el crecimiento, y tienden a incrementarse con el tiempo de exposición y la talla del cuerpo (176). La proporción, de estos metales en los mejillones verdes fue; $\mathrm{Fe}>\mathrm{Zn}>\mathrm{Cu}$, esto coincide con lo reportado para la mayoría de las especies y la familia Mytilidae no es una excepción (23). Sin embargo los metales eminentemente tóxicos, no son necesarios para los organismos como los metales esenciales, y ante la biodisponibilidad de estos en el medio los moluscos desarrollan mecanismos de defensa, mediante rutas metabólicas específicas de depuración y transformación, como es el caso del Plomo, Cadmio y Mercurio, sin dejar a un lado su capacidad de concentración por ser organismos fitradores, sedentarios y de amplia distribución $(10,177)$. 
Tabla 8. Concentración de metales esenciales en masa de Perna viridis de la bahía de Cienfuegos.

\begin{tabular}{|l|c|c|c|c|c|c|}
\cline { 2 - 7 } \multicolumn{1}{c|}{} & \multicolumn{6}{c|}{ Concentración Metales esenciales en lluvia y seca } \\
(mg/Kg peso húmedo)
\end{tabular}

Tabla 9. Concentración de metales tóxicos en masa de $P$. viridis de la bahía de Cienfuegos.

\begin{tabular}{|l|c|c|c|c|c|c|}
\cline { 2 - 8 } \multicolumn{1}{c|}{} & \multicolumn{6}{c|}{$\begin{array}{c}\text { Concentración Metales tóxicos en lluvia y seca } \\
\text { (mg/Kg peso húmedo) }\end{array}$} \\
\hline \multirow{2}{*}{ Estadígrafos } & \multicolumn{2}{c|}{ Pb } & \multicolumn{2}{c|}{ Cd } & \multicolumn{2}{c|}{ Hg } \\
\cline { 2 - 8 } & Seca & Lluvia & Seca & Lluvia & Seca & Lluvia \\
\hline Media & 0.43 & 1.34 & $<0.1$ & 0.80 & $<0.05$ & 0.07 \\
\hline Desv. Típica & 0.05 & 0.25 & - & 0.21 & - & 0.01 \\
\hline Valor t (p) & $5.104(\mathrm{p}<0.05)$ & \multicolumn{4}{|c|}{} \\
\hline Coef. variación & 12.28 & 18.65 & - & 26.73 & - & 18.45 \\
\hline Máximo & 0.51 & 1.66 & - & 0.99 & - & 0.078 \\
\hline Mínimo & 0.37 & 1.05 & - & 0.50 & - & 0.060 \\
\hline
\end{tabular}

Se experimentó un aumento significativo de casi todos los metales en la época de lluvia (mayo/2011), ver figura 4 y 5, posiblemente debido al efecto favorecedor de la bioacumulación de metales que ejercen las mayores temperaturas del agua de esta época en los moluscos (178). En este sentido Rajkumar y colaboradores (179) encontraron que el aumento de la temperatura generalmente favorece la tasa metabólica de los organismos, ayudando así al proceso de acumulación de metales presentes en el medio. Estudios realizados por Lakshmanan y Nambisan (180), en los moluscos bivalvos Villorita cypirinoides var. Cochinensis, Meretrix casta y Perna viridis indican altas concentraciones de los niveles de de $\mathrm{Cu}, \mathrm{Zn}$ y $\mathrm{Pb}$ en períodos de lluvia con baja salinidad y $\mathrm{pH}$, así como bajas concentraciones en época seca de alta salinidad y pH. Este hecho pudiera sugerir que la salinidad juega un papel importante en la 
concentración de estos metales en las partes blandas, siendo en estas condiciones más accesibles para estos organismos en el medio. Como parte del proyecto general en el que se enmarca esta investigación también se monitorearon las características hidrológicas de la bahía de Cienfuegos y se encontró que el parámetro de salinidad mostró gradientes espaciales y temporales asociados a las diferentes épocas del año, aunque cierta estabilidad en la columna de agua (33), Lemus y colaboradores (11) y Salazar y colaboradores (181); encontraron que la lluvia y la escorrentía eran fuentes importantes de metales pesados en la región costera de la península de Araya, registrando una fuerte correlación entre las variaciones de pluviosidad y las concentraciones de metales pesados.

Como los metales esenciales ( $\mathrm{Fe}, \mathrm{Zn}$ y $\mathrm{Cu}$ ) no están regulados para los moluscos bivalvos en la norma cubana, aunque si se plantea la ingesta diaria admisible (IDA). Podemos plantear que el consumo de una ración de $100 \mathrm{~g}$ de mejillón verde (asumiendo los valores más elevados obtenidos en lluvia), no sobrepasan los niveles máximos de ingestión tolerable establecidos para la población cubana adulta (164).

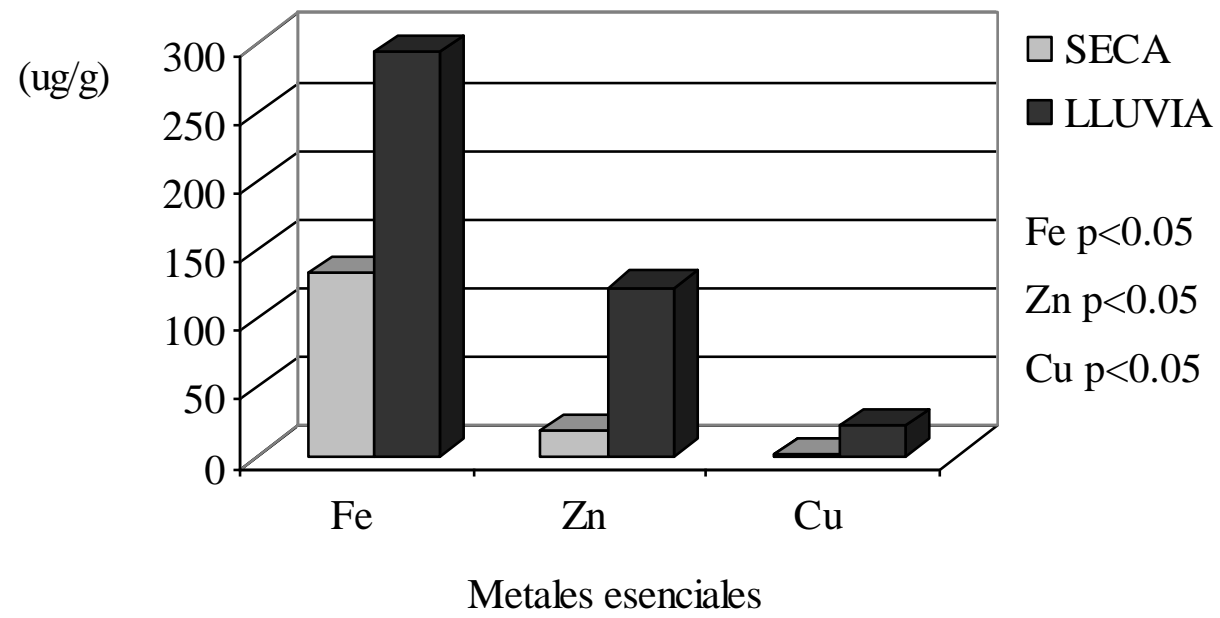

Figura 4. Metales esenciales en fracción comestible de P.viridis de la Bahía de Cienfuegos en lluvia y seca. 


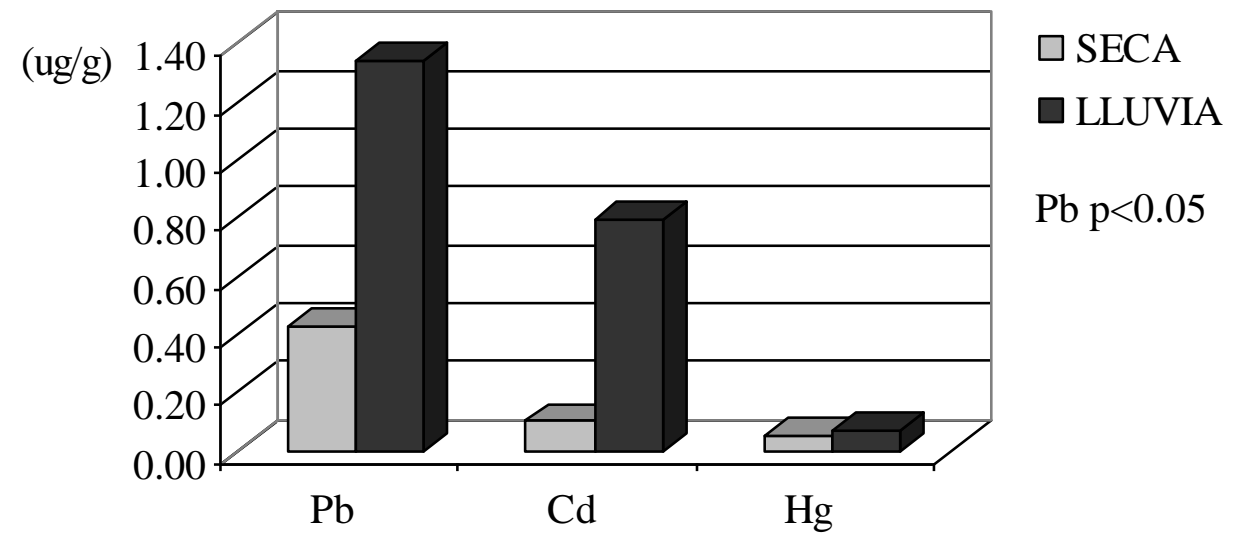

Metales tóxicos

Figura 5. Metales eminentemente tóxicos en fracción comestible de P.viridis de la Bahía de Cienfuegos en lluvia y seca.

Otro aspecto que puede influir en el aumento de los metales pesados en el mejillón verde es la disponibilidad de estos metales en la zona de estudio en época de lluvia, debido al incremento de las corrientes de agua de los afluentes durante las lluvias, que aumentan la turbidez de las aguas en los puntos de impacto en la bahía, con resuspensión de los metales que se encuentran en el sedimento. Como se había comentado en el epígrafe de la revisión bibliográfica, la bahía de Cienfuegos es una de las que recibe un mayor impacto antrópico en Cuba, junto con las de La Habana, Puerto Padre, Guantánamo y Matanzas (130, 131, 132, 133). Como parte de los residuales que se descargan en ella, se encuentran los metales pesados. Estudios realizados en los últimos años corroboran la alta contaminación del sedimento por diferentes elementos como: Plomo, Cobre, Arsénico, Vanadio, entre otros (134) en esta bahía. Al mismo tiempo otra fuente de metales pesado pueden ser los hidrocarburos vertidos en sus aguas, reportados por Tolosa y colaboradores (31).

No obstante, el incremento experimentado por todos los metales eminentemente tóxicos como $\mathrm{Pb}, \mathrm{Cd}$ y $\mathrm{Hg}$, ninguno de los dos períodos analizados sobrepasan los límites máximos de residuos estipulados para estos metales en la Norma Cubana vigente (86), ni en otras normas internacionales, como se puede observar en la figura 6. Sin embargo es necesario mantener una vigilancia en caso de ser aprobado su consumo puesto que una muestra presento un valor de concentración en el caso de la determinación de $\mathrm{Pb}$, que sobrepasó en época de lluvia lo 
establecido (86), aunque este no determinó que la media para esta temporada, estuviera por encima de LMR para este metal.

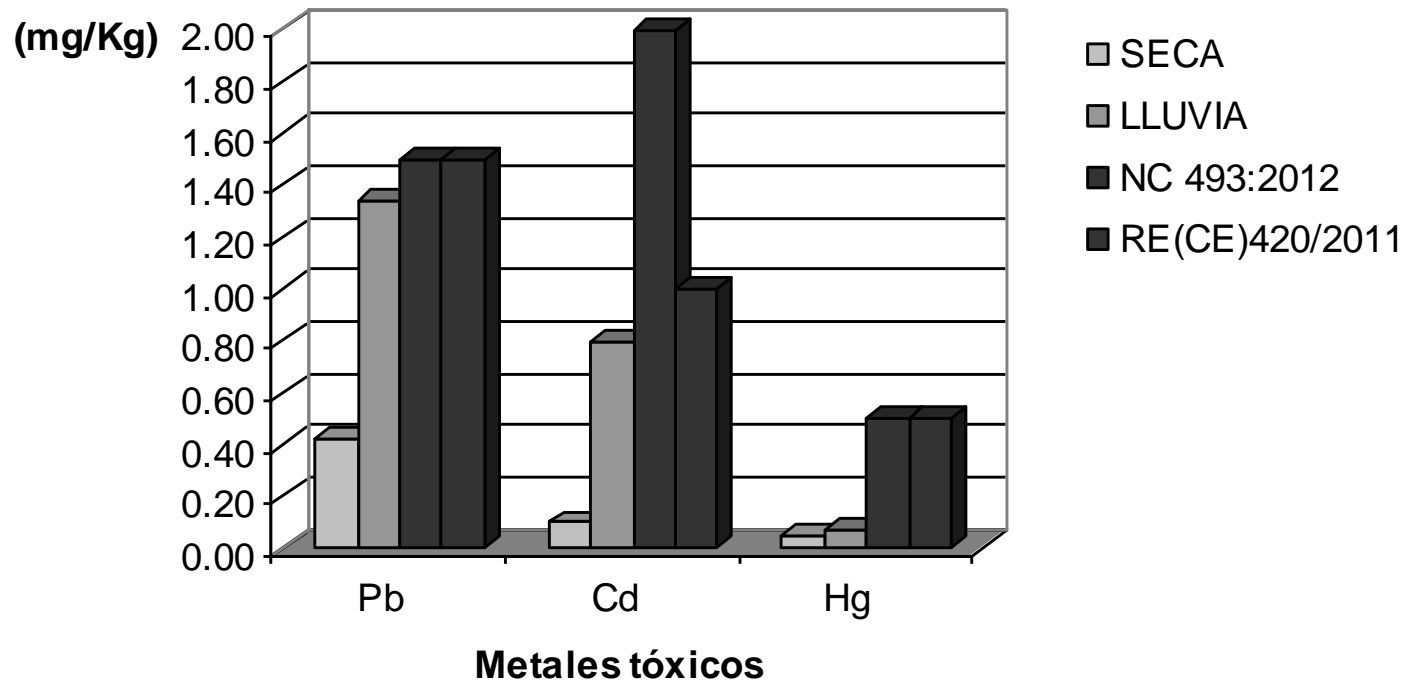

Figura 6. Valores de metales tóxicos en la masa del mejillón verde Perna viridis comparados con lo establecido en la norma cubana (86) y la norma vigente para la Comunidad Europea (85).

\section{III.6 COMPUESTOS ORGÁNICOS PERSISTENTES}

\section{III.6.1 HidROCARBUROS AROMÁTICOS POLICÍCLICOS}

En la figura 7 se muestran las concentraciones promedios de las dos determinaciones de cada uno de los Hidrocarburos Aromáticos Policíclicos (HAPs) presentes en la muestra de mejillón verde evaluada. 
Figura 7. Concentración promedio en $\mu \mathrm{g} / \mathrm{kg}$ de peso fresco de los Hidrocarburos Aromáticos Policíclicos encontrados en el pool de mejillones.

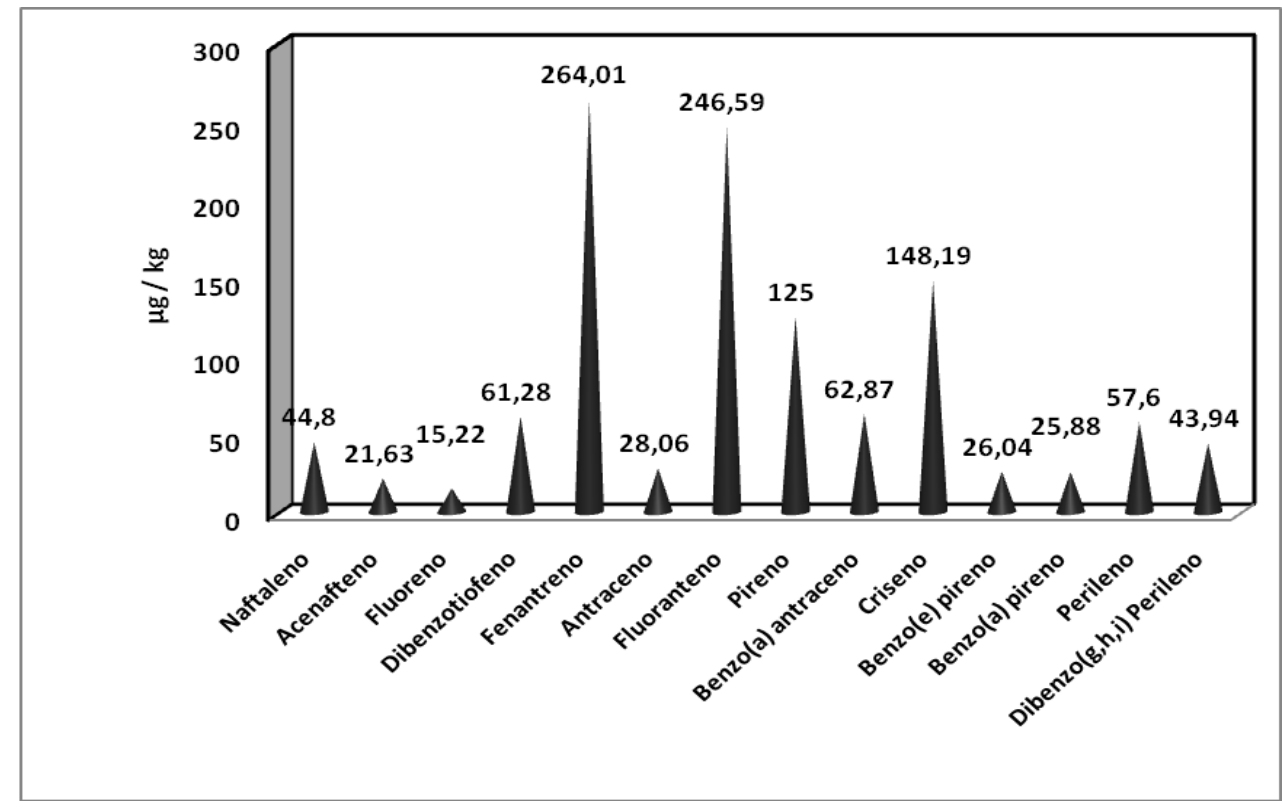

En la figura 8, se representa el porcentaje de cada uno de los HAPs determinados con respecto a la cantidad total de HAPs detectados. Las mayores contribuciones de hidrocarburos aromáticos fueron aportadas por: Fenantreno, Fluoranteno, Criseno y Pireno; con: 22.5, 21.0, 12.7 y $10.7 \%$ respectivamente del total de los hidrocarburos encontrados.

Figura 8. Porcentajes de los HAPs encontrados en el pool de mejillones.

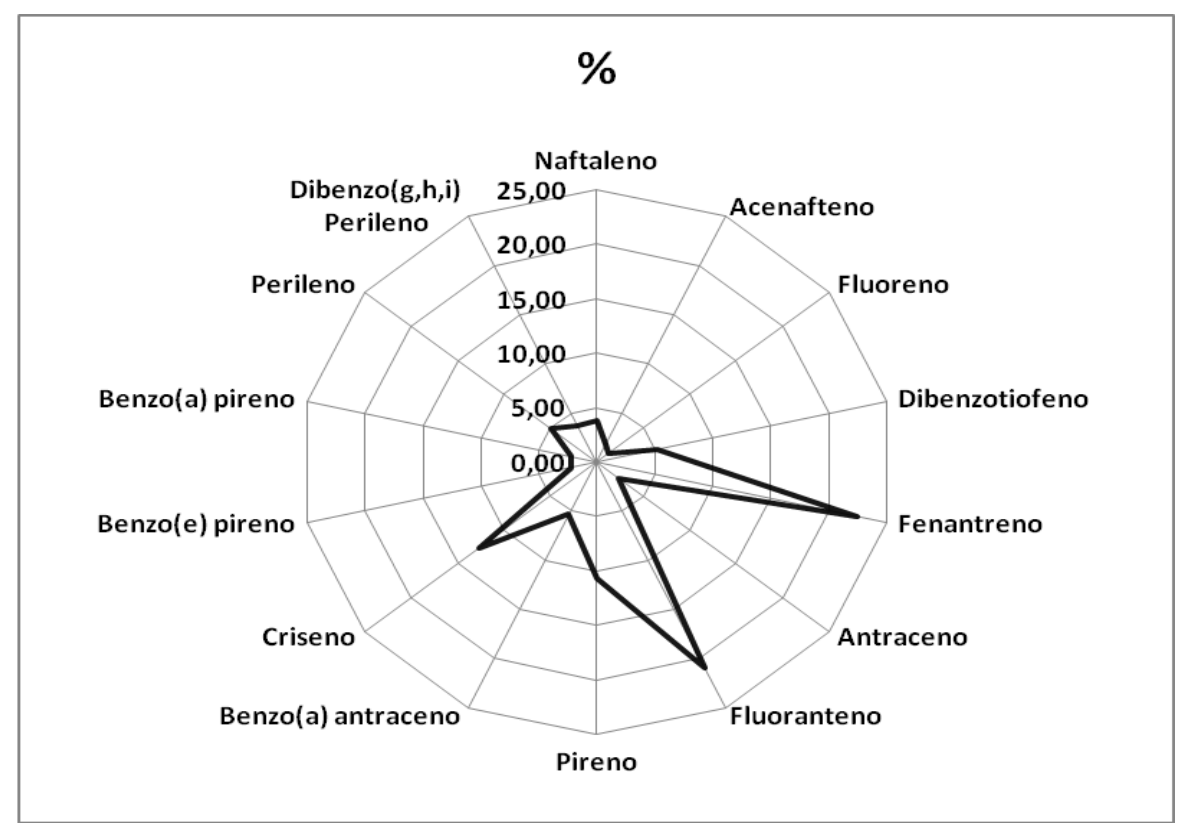


Para una caracterización de las posibles fuentes de contaminación de los HAPs encontrados, se evaluaron las relaciones entre HAPs más estudiadas que son; fenantreno/antraceno, fluoranteno/pireno y fluoranteno/fluoranteno + pireno $(182,183,184)$. Estos criterios están basados en la composición y patrón de distribución de HAPs en función de la fuente de emisión, debido a que cada fuente de contaminación genera una distribución característica entre los diferentes HAPs. Los resultados obtenidos se muestran en la Tabla 10. Una relación Fenantreno / Antraceno < 10 como resultó en nuestro estudio, indica que la contaminación tiene un origen producto de procesos de combustión incompleta de combustibles fósiles y pirolisis de materia orgánica $(104,105)$, algo similar a lo ocurrido con el resto de las relaciones evaluadas, que indicaron que las fuentes de contaminación encontradas fueron en todos los casos de origen pirogénicas, ver Tabla 10. El origen pirogénico de los HAPs en este punto de muestreo, ello concuerda con lo reportado por Tolosa y colaboradores en el 2009 (31), en el estudio espacial de los hidrocarburos en los sedimentos de la bahía de Cienfuegos, donde plantean que la presencia de HPAs de origen pirogénico es extremadamente alta en los puntos al sudeste de la ciudad de Cienfuegos (31). Un comportamiento similar se observó en un estudio realizado en la bahía de Guantánamo donde el predominio de HAPs según las relaciones encontradas fue de origen pirogénico atribuido a la combustión incompleta de petróleo y compuestos relacionados en los motores de combustión interna y termoeléctricas, los incendios forestales y la incineración de desechos urbanos (138). Factores similares pueden haber incidido en los resultados obtenidos en esta bahía, por la cercanía de la termoeléctrica, el polo industrial y la ciudad al punto utilizado para el muestreo en estos análisis.

Tabla 10. Relaciones entre HAPs y valor de estas relaciones encontradas en el pool de mejillones analizados.

\begin{tabular}{|c|c|c|c|}
\hline Relación entre HAPs & Petrogénico & Pirogénico & Valor encontrado \\
\hline Fenantreno/Antraceno & $\geq 10$ & $<10$ & 9,41 \\
\hline Fluoranteno/Pireno & $<1$ & $\geq 1$ & 1,97 \\
\hline $\begin{array}{c}\text { Fluoranteno/Fluoranteno }+ \\
\text { Pireno }\end{array}$ & $\leq 0,5$ & $>0,5$ & 0,66 \\
\hline
\end{tabular}

En la figura 9 se muestran los porcentajes de los HAPs cancerígenos ó posibles cancerígenos (Benzo (a) pireno, Benzo (a) antraceno y el criseno) de forma individual y como sumatoria, la 
que representa un $20.33 \%$ del total de HAPs presentes en la muestra. De acuerdo a estudios realizados por la Agencia Internacional de Investigaciones del Cáncer, el Benzo (a) pireno ha sido considerado como agente carcinógeno humano en el grupo 1, en tanto los dos restantes Benzo (a) antraceno y Criseno como posibles carcinógenos para humanos en el grupo 2B (16, $105)$.

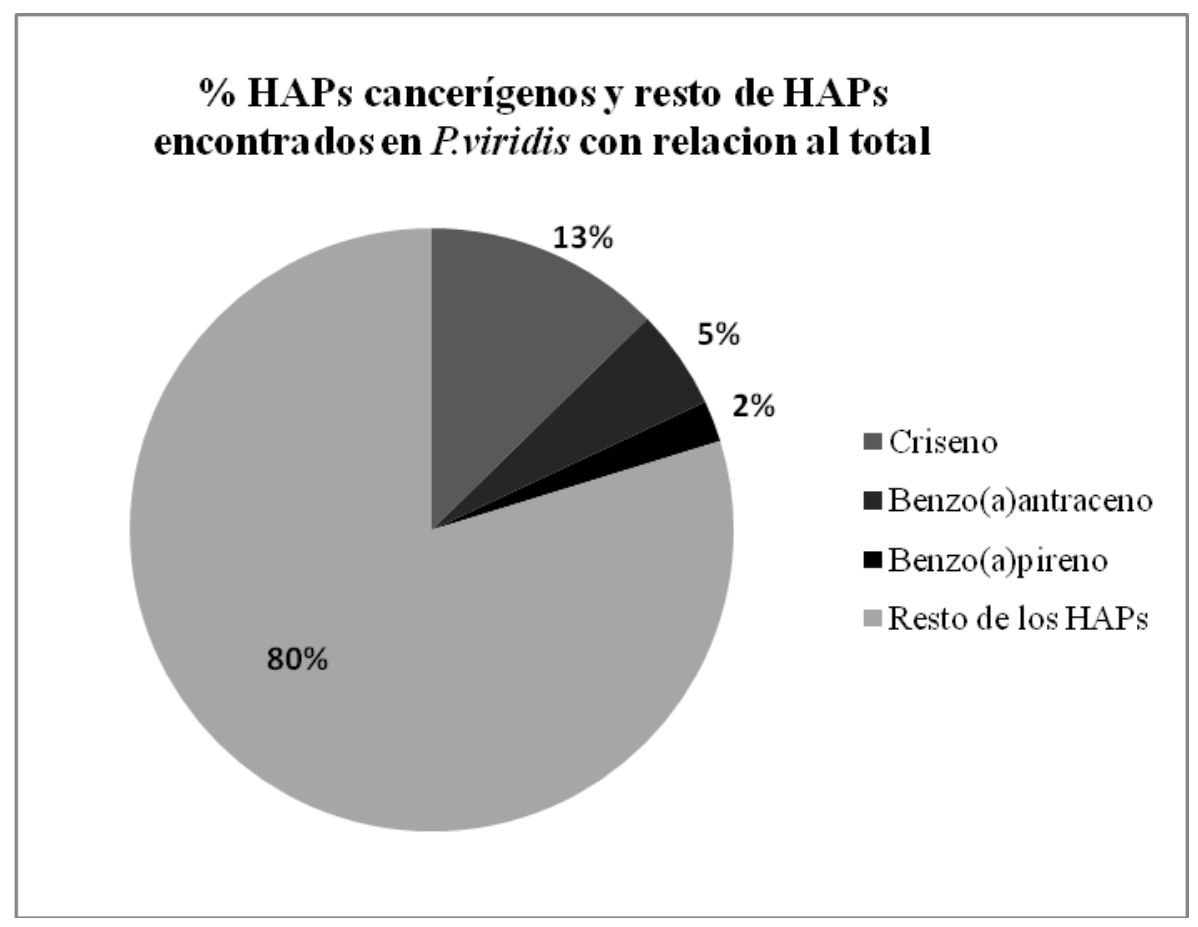

Figura 9. Porcentajes de HAPs cancerígenos y del resto de los HPAs encontrados en P.viridis de la Bahia de Cienfuegos en relación con el total.

En la figura 10, se muestra el contenido de benzo(a)pireno encontrado en el pool de mejillones, cuyo valor sobrepasó cinco veces el límite máximo de residuo permitido de $5 \mathrm{ug} / \mathrm{Kg}$ de peso fresco establecido para la Comunidad Europea (107) y en 2.5 veces el establecido en la resolución del MINAL para moluscos bivalvos (10 ug/Kg) (109). 


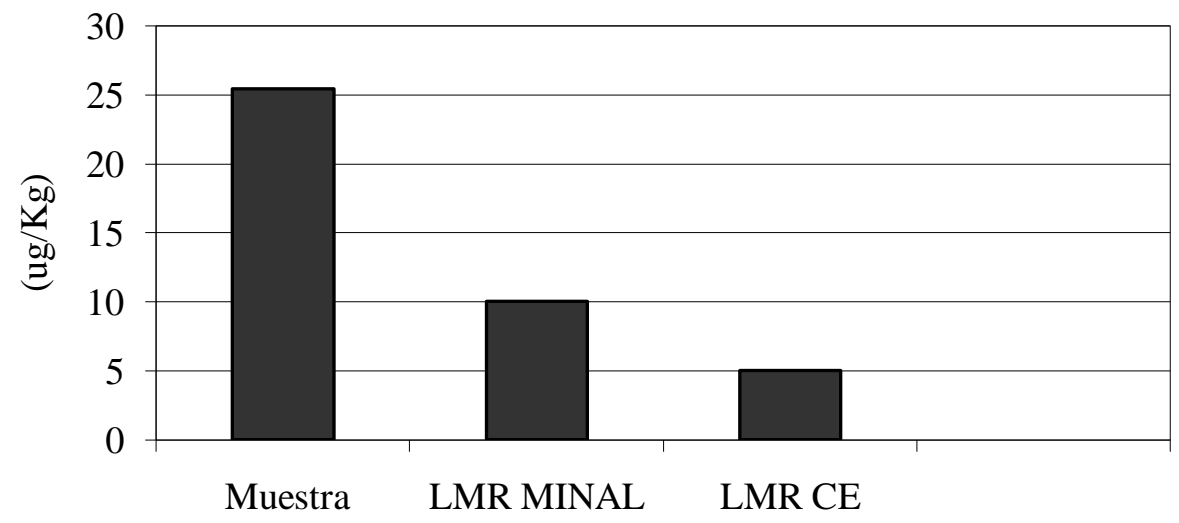

Benzo(a)pireno

Figura 10. Concentración de benzo(a)pireno en la masa de mejillones y límite máximo de este residuo establecido por Cuba (109) y la Comunidad Europa (107).

Algo similar sucedió con los residuos máximos permitidos para la suma de benzo(a)pireno, benzo(a)antraceno, benzo(a)fluoranteno y criseno (ver Figura 11), donde se observa que las sumatorias de las concentraciones promedio de estos hidrocarburos policíclicos fue de 236.94 $\mu \mathrm{g} / \mathrm{kg}$ de peso húmedo, valor este muy superior, al valor máximo permitido de $30 \mu \mathrm{g} / \mathrm{kg}$ aceptado por la Comunidad Europea (107).

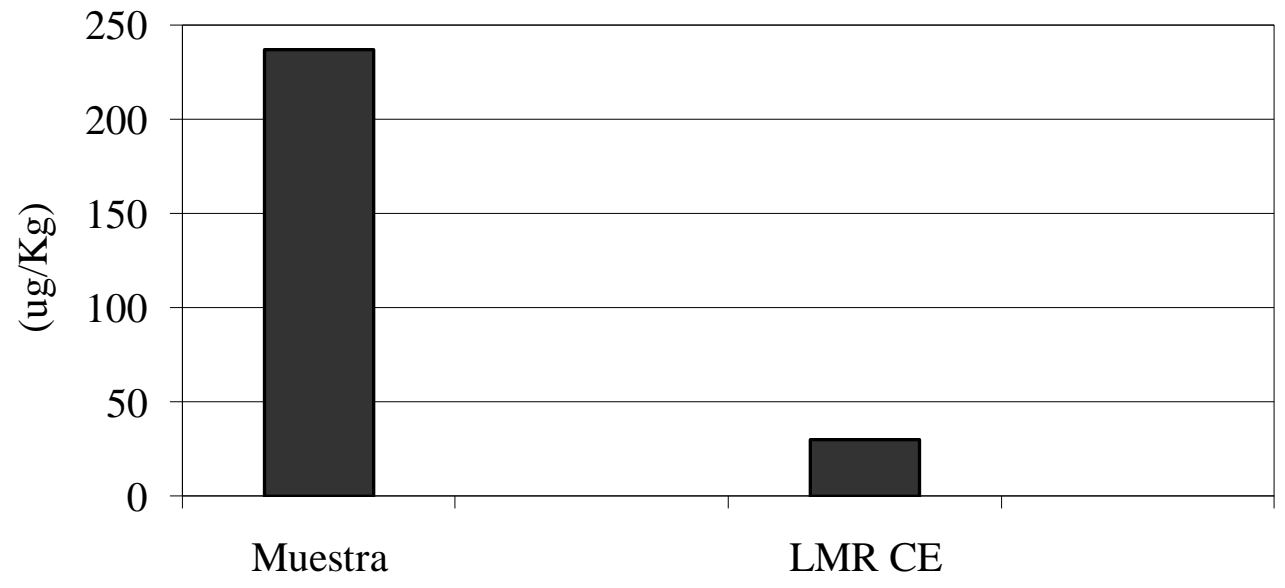

HAP4

Figura 11. Sumatoria de las concentraciones de benzo(a)pireno, benzo(a)antraceno, benzo(a)fluoranteno y criseno (HAP4) y límite máximo de residuo establecido por la Comunidad Europea para este grupo. 
Podemos plantear que los mejillones verdes (P.viridis) de este punto de muestreo de la Bahía de Cienfuegos no resultaron aptos para el consumo humano por el alto contenido de HAPs clasificados como cancerígenos y posibles cancerígenos para el hombre. Sin embargo estos resultados no deben diferenciarse de manera significativa del resto de los puntos muestreados, si tenemos en cuenta los resultados del estudio del comportamiento de las corrientes y distribución de la contaminación en esta zona realizado por Muñoz en el 2011 (27). Este autor reporta que el lóbulo norte de la bahía presenta un largo tiempo para realizar su total intercambio de agua (60 días), en tanto el lóbulo sur lo completa solo en 6 días.

Llegar a una evaluación de riesgo de padecer cáncer por el consumo de estos mejillones es mucho más complejo, no obstante un estudio realizado por Mirsadeghi y colaboradores (108). Sobre la determinación de concentraciones de HAPs en la masa del molusco bivalvo (Anadara granosa), sedimento y agua; de diferentes zonas de la península de Malasia y el riesgo de su consumo tanto para personas residentes (incluyendo niños) como no residentes en las zonas estudiadas, dio como resultado que la sumatoria de los HAPs carcinogénicos presentó un valor de $43.06 \pm 4.00 \mathrm{ug} / \mathrm{Kg}$ de peso húmedo del molusco, valor muy inferior al encontrado en nuestro estudio $(236.94 \mu \mathrm{g} / \mathrm{kg})$. Mientras que la posibilidad de padecer cáncer por la ingesta de este molusco en las zonas estudiadas varió desde $(9.79 \pm 1.20)$ x $10^{-5}$ a $(2.06 \pm 0.06)$ x $10^{-4}$, siendo muy inferior para los consumidores no residentes (108). Esta investigación antes señalada nos da la idea del riesgo al que pueden estar expuestos los posibles consumidores de los mejillones verdes de la bahía de Cienfuegos, prestando especial interés a los grupos de riesgo (niños, embarazadas y ancianos), donde las consecuencias pueden ser mas graves. Además sería de gran utilidad extender estos análisis en mejillones de otros puntos de la bahía, aunque según lo reportado por Tolosa y col, esta zona del acuatorio fue clasificada como la de mayor contaminación por HAPs (7900 a 10500 ug/Kg de sedimento) y se estima que toda la bahía recibe alrededor de 2 t/año de HAPs (31).

\section{III.6.2 PlaGUiCIDAS ORGANOCLORADOS}

En la tabla 11 se muestran los resultados obtenidos para los plaguicidas organoclorados incluidos en el Convenio de Estocolmo (103). En nuestro análisis se observa la siguiente secuencia de distribución: Heptacloro $>$ Drins $>$ Clordanes $>$ DDTs $>$ Mirex $>$ HCB. A diferencia con nuestro estudio, en este mismo año investigadores del CEAC, encontraron en 
Perna viridis de talla comercial de esta bahía, una secuencia de distribución de: DDTs > Dieldrin $>$ Clordanes $>$ Endosulfan $>$ HCB $>$ Aldrin $>$ Heptacloro $>$ Lindano (30), la diferencia principal radicó en las concentraciones de Heptacloro que para nosotros fueron mayores y para ellos prácticamente las menores. Esto pudiera estar dado por las diferentes técnicas de determinación utilizadas, por la época del año y por la diferencia entre los puntos de muestreo de cada trabajo, pues en este estudio se muestreo en la costa sureste de la ciudad y en el otro trabajo justo en la costa suroeste, es decir alejado de la ciudad, del polo industrial y de la desembocadura de los ríos Salado y Damují que riegan importantes áreas agrícolas, explotadas en los últimos 40 años (30). No obstante las diferencias, ambos trabajos corroboran la presencia en los mejillones verdes de insecticidas organoclorados, que antes fueron reportados por Tolosa y colaboradores en los sedimentos de este acuatorio (32). Lo que constituye un riesgo para los posibles consumidores de estos moluscos, pues en desacuerdo con los investigadores del CEAC (30), que plantean que para estos compuestos analizados no existen LMR establecidos, por lo que no constituyen un problema, en realidad ocurre todo lo contrario porque su presencia no es permitida en los productos de la pesca para consumo humano, tanto para Cuba como para la Comunidad Europea y otros países del mundo $(109,185)$. Otro aspecto importante a tener en cuenta es que en ambos casos las concentraciones encontradas en los mejillones (30) fueron superiores a las reportadas en lo sedimentos (32), ello demostró la capacidad de los bivalvos de concentrar estos COPs presentes en el medio. Un estudio comparativo entre mejillones y membranas semipermeables en diferentes zonas costeras contaminadas de Hong Kong, reafirma lo antes planteado, pues muestra mayores concentraciones de pesticidas organoclorados en P.viridis con respecto a las membranas (186). Además, como los mejillones se consumen preferentemente cuando están próximos al desove y presentan mayores concentraciones lipídicas, tejido donde se acumulan los COPs (100, 101, 102), pueden presentar las mayores concentraciones de estos compuestos a la hora de ser cosechados, si están disponibles en el medio. 
Tabla 11. Plaguicidas Organoclorados en la fracción comestible de P.viridis de la Bahía de Cienfuegos.

\begin{tabular}{|c|c|c|c|c|c|}
\hline \multicolumn{7}{|c|}{$\begin{array}{c}\text { Concentraciones Plaguicidas Organoclorados } \\
\text { (ng/g peso húmedo) en masa de } \text { P.viridis }\end{array}$} \\
\hline HEPTACHLOR & DRINS & CLORDANES & DDTs & MIREX & HCBs \\
\hline 17,27 & 4,23 & 3,1 & 2,74 & 0,857 & 0,4 \\
\hline
\end{tabular}

\section{III.6.3 DIOXINAS/FURANOS, POLICLOROBIFENILOS SIMILARES Y NO SIMILARES A LAS DIOXINAS}

En la tabla 12, se muestran la sumatoria de las concentraciones de Dioxinas y Furanos, por sus siglas en inglés (PCDDs y PCDFs), la sumatoria de las concetraciones de Policlorobifenilos similares a las Dioxinas, por sus siglas en inglés (DL-PCBs,) y los Policlorobifenilos no similares a Dioxinas indicadores, por sus siglas en inglés (NDL-PCBs).

Los resultados de PCDD/PCDFs y DL-PCBs se expresa en valores de equivalencia tóxica de la Organización Mundial de la Salud (OMS-TEQ), que se calcula mediante el sumatorio de multiplicar el factor de equivalencia toxica TEF (siglas en inglés), de cada congénere, por su concentración en la muestra. El TEF que tiene asignado cada congénere es relativo a la toxicidad de compuesto 2, 3, 7, 8 tetraclorodibenzo-p-dioxina, la dioxina clasificada como más tóxica $(115,116)$.

Tabla 12. Concentraciones de Dioxinas/furanos y Policlorobifenilos similares a Dioxinas e indicadores en fracción comestible de P.viridis de la bahía de Cienfuegos.

\begin{tabular}{|c|c|c|}
\hline \multicolumn{3}{|c|}{$\begin{array}{c}\text { Concentraciones de Dioxinas/Furanos y Bifenilos Policlorados similares a } \\
\text { Dioxinas e indicadores en masa de } \boldsymbol{P} \text {.viridis }\end{array}$} \\
\hline PCDD/PCDFs & DL-PCBs & $\begin{array}{c}\text { NDL-PCBs } \\
\text { (indicadores) }\end{array}$ \\
\hline \multicolumn{2}{|c|}{$(\mathrm{pg}$ OMS-TEQ/g peso fresco) } & (ng/g peso fresco) \\
\hline 0,38 & 7,61 & 5,54 \\
\hline
\end{tabular}

La suma de PCDD/PCDFs no sobrepasó los límites máximos establecidos para los productos de la pesca por la Comunidad Europea y Cuba, 3.5 pg/g peso fresco $(109,116)$, 
comportamiento similar a los valores alcanzados por los mejillones en la región de Cataluña (0,137 pg OMS-TEQ/g peso fresco), en el periodo 2005-2007.

En el caso de los NDL-PCBs indicadores nuestros resultados quedaron por debajo del LMR establecido por la Comunidad Europea, $75 \mathrm{ng} / \mathrm{g}$ peso fresco (116) y este límite no está incluido en la normativa cubana (109).

En tanto la suma de PCDD/PCDFs y DL-PCBs que alcanzó un valor de 7,99 pg/g, si sobrepasó el límite establecido (6.5 pg/g peso fresco) por ambas normativas (109, 116). Estos compuestos al igual que otros COPs se acumulan en el tejido graso de los mejillones y como su consumo es justo antes del desove (cuando presenta una mayor concentración de lípidos) aumenta la posibilidad de que presenten mayores acumulados de COPs y sea mayor el riesgo de afectar la salud de los consumidores. Las cantidades producidas en una determinada zona de dioxinas son de difícil cuantificación, pues son subproductos de la incineración de residuos, el blanqueado del papel, la producción de plaguicidas y de plásticos polivinil-clorados, mientras la manufactura y procesado de PCBs, está prohibida en casi todo el mundo (187). Como parte del proyecto SAICM/UNEP "Creación de Capacidades para Laboratorios de COP en Cuba, también se realizaron análisis de sedimento en la bahía de Cienfuegos, en el que se encontró presencia de estos compuestos pero en menor cantidades que las detectadas en el mejillón, de ahí que los bivalvos sean utilizadas en muchos estudios como especies bioindicadoras de contaminación ambiental $(188,189,190)$.

Las dioxinas o compuestos similares a ellas, son agentes químicos que afectan el sistema endocrino, es decir, pueden entrar a las células y obstruir, imitar o alterar las acciones de las hormonas, pudiendo tener efectos negativos en el desarrollo neurológico, reproductivo, conductual y en el sistema inmunológico. Lo que puede propiciar que se contraigan más fácilmente enfermedades infecciosas. Sin embargo los efectos más indeseables son los riesgos de padecer cáncer por la exposición a estas sustancias. Diversos estudios a largo plazo en distintas especies de animales (ratones, ratas y hámster) y algunas evidencias en humanos indican que los PCBs y las dioxinas son carcinógenos, posiblemente relacionado con el receptor aril hidrocarburo, un factor de transcripción que afecta la expresión genética. Se han relacionado con la aparición de cáncer en distintas partes del organismo como hígado, 
pulmones, lengua, parte superior de la boca, nariz, glándula tiroides, glándula adrenal, en la piel de la cara y bajo la piel $(16,187,191)$.

Las determinaciones que se hicieron de COPs en el mejillón verde (P.viridis) de la Bahía de Cienfuegos, determinaron la presencia de tres grupos de compuestos que entrañan altos riesgos a la salud humana (HAPs, PCDD/PCDFs + DL-PCBs y Pesticidas Organoclorados), sobre todo por sus propiedades carcinogénicas declaradas por la Agencia Internacional de Investigaciones contra el Cáncer (16).

La secuencia de concentraciones encontradas en este bivalvo fue: HAPs > PCDD/PCDFs + DL-PCBs > DDT coincidiendo con otros autores para bivalvos de la misma familia (192), aunque estas relaciones estarán influenciadas por diversos factores intrínsecos, el factor más importante que determina la inocuidad de estos moluscos es la calidad de las aguas donde se desarrollen (1). 


\section{CONCLUSIONES}

- El mejillón verde (P. viridis) de la Bahía de Cienfuegos presentó un rendimiento de la fracción comestible y un aporte en proteínas, lípidos y energía superior a otros moluscos bivalvos procesados en Cuba.

- Los mejillones frescos procedentes de las zonas de muestreo no siempre cumplieron con los parámetros microbiológicos para el consumo humano, pues presentaron contaminación fecal en algunos casos.

- La cocción por tres minutos de los mejillones enteros y en media concha, resultó el procesamiento más efectivo por posibilitar una reducción de la contaminación microbiológica suficiente y alcanzar los más altos rendimientos.

- La fracción comestible de los mejillones verdes muestreados en los periodos de lluvia y seca, cumplieron con las normas vigentes tanto nacionales como internacionales en cuanto a la presencia de metales pesados.

- La porción comestible de los mejillones frescos analizados mostró una alta contaminación por encima de los límites máximos de residuos permitidos para hidrocarburos aromáticos policíclicos, así como la suma de dioxinas, furanos y policlorobifenilos similares a dioxinas.

- En las muestras analizadas se detectaron la presencia de pesticidas organoclorados prohibidos en alimentos para consumo humano.

- El mejillón verde de la Bahía de Cienfuegos aunque es un alimento de gran valor potencial para el mercado no puede consumirse a partir de las zonas de pesca estudiadas, pues no es inocuo. 


\section{RECOMENDACIONES}

- Se considera necesario alertar a las autoridades competentes que los mejillones verdes ( $P$. viridis) de la Bahía de Cienfuegos no cumplen con los requisitos de inocuidad, por tanto no pueden ser consumidos en aras de proteger la salud de la población.

- Se propone el cultivo de esta especie en zonas no contaminadas, previamente caracterizadas, tomando como fuente de larvas los sitios estudiados. Sería necesario además, realizar un estudio sistemático de todos los parámetros descritos en este estudio (incluyendo la determinación de biotoxinas y dinoflagelados tóxicos) tanto en el cultivo como en el momento de su extracción. 


\section{REFERENCIAS BIBLIOGRÁFICAS}

1. Davy FB, Graha M, editores. Cultivo de bivalvos en Asia y el Pacífico: trabajos presentados en un seminario celebrado en Singapur del 16 a 19 de febrero de 1982. Ottawa; 1984.

2. Espinosa J, Ortea J, Sánchez R, Gutiérrez J. Bivalvos. En: Moluscos marinos Reserva de la Biosfera Península de Guanahacabibes, Cuba; 2012. [Citado 2012 nov 6]. Disponible en: http://www.ecosis.cu/biocuba/documentos biocuba/moluscos marinos guanahacabibes/05 _LIBRO_MOLUSCOS_GUANAHACABIBES_2012_\%20capitulo\%204.htm

3. Ministerio de la Industria Pesquera (MIP).Anuario Estadístico de Capturas.2008.

4. Guo XS, Ford Y, Zhangf. Molluscan aquaculture in China. J. Shellfish Res.1999; 18: $19-31$.

5. Chalermwat K, Lutz R. Farming the green mussel in Thailand. World Aquacult.1989; 20: 41-46.

6. Vakily JM. The biology and culture of mussels of the genus Perna. ICLARM Studies and Reviews. 1989; 17.

7. Durá MJ, Abajas R. Enfermedades de origen alimentario intoxicaciones y toxiinfecciones alimentarias. Curso: Nutrición y Dietética. Universidad de Cantabria [Curso en Internet]. [Actualizado 2011; citado 2012 nov 30]. Disponible en: http://ocw.unican.es/ciencias-de-la-salud/nutricion-y-dietetica-2011-1/nutricion-y-dietetica2011/materiales-de-clase/tema4.pdf

8. Baqueiro ER, Borabe L, Goldaracena CG, Rodríguez J. Los moluscos y la contaminación. Una revisión. Revista Mexicana de Biodiversidad. 2007; 78: 1S- 7S.

9. Zapata E, Rojas de Astudillo L, Sánchez G, Barreto M. Metales pesados y biomarcadores relacionados en Perna viridis (Bivalvia: Mytilidae) recolectado en las costas del estado Sucre, Venezuela. Ciencias Marinas. 2012; 38(3): 517-528.

10. Rojas N, Lemus M, Rojas L, Martínez G, Ramos Y, Cheng KS. Contenido de mercurio en Perna viridis en la costa norte del Estado Sucre, Venezuela. Ciencias Marinas. 2009; 35(1): 91-99.

11. Lemus M, Laurent C, Acagua A, Cabrera M, Aponte A, Chung K. Variación estacional de metales pesados en Perna viridis, de la localidad de Guayacán, Península de Araya, Estado Sucre, Venezuela. The Biologist (Lima). 2010 jul-dic; 8(2): 126-138.

12. Yap CK, Shahbazi A, Zakaria MP. Concentrations of Heavy Metals $(\mathrm{Cu}, \mathrm{Cd}, \mathrm{Zn}$ and Ni) and PAHs in Perna viridis, collected from Seaport and Non-seaport Waters in the Straits of Johore. Bull Environ Contam Toxicol. DOI 10.1007/s00128-012-0838-x. Springer Science+Business Media. New York; 2012. 
13. Huss HH. Aseguramiento de la calidad de los productos pesqueros. Documento técnico de pesca No.334. Roma: FAO; 1997.

14. Díaz T, Caballero AE, Díaz JR. Enfermedades trasmitidas por alimentos. En: Caballero AE. Temas de Higiene de los Alimentos. La Habana: Editorial Ciencias Médicas; 2008. p. 216-248.

15. Petrera M, Montoya M. Impacto económico de la epidemia del cólera. Organización Panamericana de la Salud (OPS). Serie de Informes Técnicos No 22. OPS. Washington, DC. 1993. p. 74.

16. IARC. Agents Classified by the IARC Volumes 1-106 [monographs on the internet]; 2012 [Cited 2012 dic 23]. Available from: http://monographs.iarc.fr/ENG/Classification/ClassificationsGroupOrder.pdf

17. Fernández R, Rolán E. Primera cita de Perna viridis (L., 1758) (Bivalvia: Mytilidae) en aguas de Cuba. Noticiario SEM. 2005; 43:79.

18. Lopeztegui A, Garcés Y, Castelo R, Castro N, Artiles A. Abundance and distribution of the invading species Perna viridis (Mytiloida: Mytilidae) in the Cienfuegos Bay. En prensa 2013.

19. Gutiérrez F. Estado de conocimiento de especies invasoras. Propuesta de lineamientos para el control de los impactos. Instituto de Investigación de Recursos Biológicos Alexander von Humboldt: Bogotá D.C., Colombia; 2006.

20. Artiles A. Manejo de la especie invasora, Perna viridis (mejillón verde) de la Bahía de Cienfuegos a través de su explotación comercial como producto pesquero para consumo humano. Proyecto de Investigación: Centro de Investigaciones Pesqueras; 2011.

21. Rajagopal S, Venugopalan VP, Van der Velde G, Jenner HA. Greening of the coasts: a review of the Perna viridis success story. Aquatic Ecology. 2006; 40: 273-297.

22. Lovatelli A, Vannuccini S, McLeod D. Current status of world bivalve aquaculture and trade. En A. Lovatelli A, Farías A. Uriarte E (editors). Estado actual del cultivo y manejo de moluscos bivalvos y su proyección futura: factores que afectan su sustentabilidad en América Latina. Taller Técnico Regional de la FAO. 20-24 de agosto de 2007, Puerto Montt, Chile. Roma, FAO, Actas de Pesca y Acuicultura. 2008; 12: 45-59.

23. Sidwell VD. Chemical and Nutritional Composition of Finfishes, Whales, Crustaceans, Mollusks and their Products. NOAA Technical Memorandum. NMFS F/SEC11. 1981.

24. Cabello AM, Villarroel R, Figuera BE, Ramos MC, Márquez Y, Vallenilla OM. Parámetros de frescura de moluscos. Revista Científica, FCV-LUZ. 2004; XIV (5): 457 466.

25. Norma Codex Stan 292-2008 para los moluscos bivalvos vivos y los moluscos bivalvos crudos. 
26. Chabalina 1, Beltran j. Contaminación marina en bahías y zonas costeras de Cuba y del Gran Caribe. Informe final. CIMAB. 2000.

27. Muñoz A, García A, Douillet P, Díaz O, Fichez R, Herrera R y col. Análisis de los procesos de renovación de las aguas de la Bahía de Cienfuegos. Revista CENIC Ciencias Biológicas. 2011 sept-dic; 3(42): 125-130.

28. Seisdedo M, Moreira AR. Comportamiento de las características físico-químicas de las aguas y el fitoplancton en la bahía de Cienfuegos, Cuba. Rev. Invest. Mar. 2007; 28(3): 193-199.

29. Seisdedo M, Arencibia G, Moreira AR, Morales Y. Análisis comparativo del estado trófico de las aguas de la Bahía de Cienfuegos, Cuba (2009). Informe Final. CEAC. 2009.

30. Alonso CM, Gomez M, Villeneuve JP, Cattini Ch. Organochlorine Pesticides in Green Mussel, Perna viridis, from the Cienfuegos Bay, Cuba. Bull Environ Contam Toxicol. 2012; 89:995-999

31. Tolosa I, Mesa M, Alonso CM. Inputs and sources of hydrocarbons in sediments from Cienfuegos bay, Cuba. Marine Pollution Bulletin. 2009. Available from: www.elsevier.com/locate/marpolbul

32. Tolosa I, Mesa M, Alonso CM. Organochlorine contamination (PCBs, DDTs, HCB, HCHs) in sediments from Cienfuegos bay, Cuba. Mar Pollut Bull. 2010; 60:1619-1624.

33. Garcés Y, Betanzos A, Lopeztegui A, Artiles A. Hydrological characteristics of Cienfuegos' Bay, Cuba, related to the presence of the invasive green mussel Perna viridis. Inter. J. Of Marine Science. 2012; 2(2): 12-17.

34. Codex Alimentarius, Food Hygiene Basic Texts, 1997. Recommended International Code of Practice. General Principles of food hygiene. CA/RCP 1-1969, 1997; rev. 3.

35. FAO/OMS. Garantía de la inocuidad y calidad de los alimentos: directrices para el fortalecimiento de los sistemas nacionales de control de los alimentos [Monografía en Internet]. [S/F; Citado 2012 nov 30]. Disponible en: http://www.who.int/foodsafety/publications/capacity/en/Spanish Guidelines Food control. pdf

36. Siddall S. A clarification of the genus Perna (Mytilidae). Bulletin of Marine Science. 1980; 30: 858-870.

37. The Asian Green Mussel: Recent Introduction to the South Atlantic Bight. Southeastern Regional Taxonomic Center, South Carolina Department of Natural Resources. [Page last updated: 2009 Oct 4; cited 2012 April 15]. Available from: http://www.dnr.sc.gov/marine/sertc/

38. Rajagopal S. The ecology of tropical marine mussels and their control in industrial cooling water systems. [dissertation] (Ph.D): University of Nijmegen, Netherlands; 1997. 
39. Masterson J. Smithsonian Marine Station. [Page last updated: 2007 Oct 4; cited 2012 April 15]. Available from: http://www.sms.si.edu/irlspec/perna_viridis.htm

40. López JA. Taza de filtración y aclaramiento en la almeja mano de león (Nodipecten subnodosus Sowerby, 1835) a dos tallas, en función de la temperatura y la cantidad del alimento [tesis]. Programa de estudios de postgrado: Centro de Investigaciones Biológicas del Noreste, S.C, la Paz; 2003.

41. Power AJ, Walker RL, Payne K, Hurley D. First occurrence of the non indigenous green mussel, Perna viridis in coastal Georgia, United States. Journal of Shellfish Research. 2004; 23:741-744.

42. Acosta V, Prieto A, Lodeiros C. Índice de condición de los mejillones Perna perna y Perna viridis (Bivalvia: Mytilidae) bajo un sistema suspendido de cultivo en la Ensenada de Turpialito, Golfo de Cariaco, Venezuela. Zootecnia Trop. 2006; 24(2): 177-192.

43. Fatima M. Growth indices, nutritive value and chemical significance of the green mussel [dissertation]. (Ph.D): University of Karachi; 1996.

44. Sreenivasan P, Thangavelu R, Poovannan P. Biology of the green mussel, Perna viridis (Linnaeus) cultured in Muttukadu lagoon, Madras. Indian. J. Fish. 1989; 36: 149155.

45. Rajagopal S. Biofouling problems in the condenser cooling circuit of a coastal power station with special reference to green mussel, Perna viridis (L.) [Dissertation]. (Ph.D): University of Madras; 1991.

46. Rubio M. Determinación de la época de máxima actividad reproductiva de la especie. En: Artiles A. Manejo de la especie invasora, Perna viridis (mejillón verde) de la Bahía de Cienfuegos a través de su explotación comercial como producto pesquero para consumo humano. Informe anual, Proyecto de Investigación: Centro de Investigaciones Pesqueras; 2011.

47. Benson A, Marelli DC, Frescher ME, Danforth JM, William SJD. Establishment of the green mussel Perna viridis (Linnaeus 1758), Mollusca: Mytilidae, on the west coast of Florida. Journal of Shellfish Research. 2001; 20(1): 21-29.

48. Agard J, Kishore R. Perna viridis (Linnaeus, 1758): First records of the Indo-Pacific green mussel (Mollusca: Bivalvia) in the Caribbean. Caribbean Marine Studies. 1992; 3:5960 .

49. Rylander J, Pérez J, Gómez J. Status of the green mussel Perna viridis (Linnaeus, 1758) (Mollusca: Mytilidae) in north-eastern Venezuela. Caribbean Marine Studies. 1996; 5: 86-87.

50. Buddo D, Steele RD, D’Oyen ER. Distribution of the invasive Indo-Pacific green mussel, Perna viridis, in Kingston Harbour, Jamaica. Bulletin of Marine Science. 2003; 73: 433-441. 
51. Baker P, Fajans J, Arnold W, Ingrao D, Marelli D, Baker S. Range and Dispersal of a tropical marine invader, the asian green mussel, Perna viridis, in subtropical waters of the southeastern United States. Journal of Shellfish Research. 2007; 26 (2): 345-355.

52. Convenio Sobre la Diversidad Biológica (2002) Conferencia de las partes: Examen y consideración de las opciones de aplicación del artículo 8 h) sobre especies exóticas que amenazan a los ecosistemas, hábitats o especies. UNEP/CBD/COP/6/18/Add.1/Rev.1

53. Betanzos A. Estado actual de la producción de ostión de mangle en la región norcentral de Cuba, variabilidad e impactos naturales y antrópicos. Informe de Proyecto: GEF PNUD protección al Ecosistema Sabana-Camaguey. 3ra etapa. Centro de Investigaciones Pesqueras. Ministerio de la Industria Alimentaria; 2012.

54. Organización de las Naciones Unidas para la Alimentación y la Agricultura, Departamento de Pesca y Acuicultura de la FAO. El Estado Mundial de la Pesca y la Acuicultura 2012. Roma; 2012.

55. FAO FishFinder [database on the internet]. Species Fact Sheets. [cited 2012 nov 7]. Available from: http://www.fao.org/fishery/species/2691/en

56. Lovatelli A. El comercio de bivalvos en Europa. Infopesca Internacional. 2003; Ene-Mar 13.

57. Mazón-Suástegui JM. Obtención de semillas y cultivo de mejillón del mediterráneo Mytilus sp: Avances y perspectivas en España. Conferencia presentada en: Proyecto piloto para cultivo de ostión de mangle Cassostrea rhizophorae en Isabela de Sagua. CIBNOR, S.C. México; 2011.

58. Carvajal R. Fluctuación mensual de las larvas y crecimiento del mejillón Perna perna (L) y las condiciones ambientales en la ensenada de Guatapanare, Estado Sucre, Venezuela. Bol. Inst. Oceanogr. Univ. Oriente. 1969; 8(1): 13-20.

59. Lodeiros C, Rengel J, Guderley H, Nusetti O, Himmelman J. Biochemical composition and energy allocation in the tropical scallop Lyropecten (Nodipecten) nodosus during the months leading up to and following the development of gonads. Aquaculture. 2001; 199: 63-72.

60. Natera YJ. Composición bioquímica de los mejillones Perna perna y Perna viridis bajo sistema de cultivo suspendido en la Ensenada de Turpialito [tesis]. Modalidad Investigación (MI).Universidad de Oriente; 2010.

61. Acosta V, Natera Y, Lodeiros C, Freites L, Vásquez A. Componentes bioquímicos de los tejidos de Perna perna y P. viridis. Lat. Am. J. Aquat. Res. 2010; 38(1): 37-46.

62. Acosta V, Montes M, Cortez R, Guevara M, Lodeiros C. Crecimiento del mejillón verde Perna viridis (Bivalvia: Mytilidae) bajo sistema de cultivo de fondo en la ensenada de Turpialito, Golfo de Cariaco, Venezuela. Rev. Biol. Trop. 2012 Dec; 60(4): 1749-1762.

63. Villarroel R, Cabello A, Figuera B, Vallenilla O. Características bromatológicas de moluscos comerciales. Memorias del VI Congreso Científico de la Universidad de Oriente. 
5 al 7 diciembre. [Actualizado Dic 2001; citado Oct 2012]. Disponible en: File://D:\ALIMENTOS\TA006.HHTM. Diciembre.

64. Koftayan T, Milano J, D’Armas H, Salazar G. Perfil de lípidos y ácidos grasos de Perna viridis, mejillón verde (Mollusca: Bivalvia) en el oriente venezolano y la costa oeste de Trinidad. Rev. Biol. Trop. 2011 March; 59(1): 171-182.

65. Fichas Nutricionales. Mejillones. [Actualizado 2012; citado 2012 nov 19]. Disponible en: http://www.dietasmatematicas.es/fichas/mejillón.htm

66. Gilio JL, Vigo Sal MK. Biorremediación de los efluentes de la acuicultura.[Monografía en Internet]; 2007. [Citado 2012 dic 4]. Disponible en: http://www.aquahoy.com/index.php?option=com_content\&view=article\&id=208\%3Abiorr emediacion-de-los-efluentes-de-la-acuicultura\&Itemid=64\&lang=pt

67. Lin C, Ruamthaveesub P, Wanuchsoontorn P. Integrated culture of the green mussel Perna viridis in wastewater from an intensive shrimp pond: concept and practice. World Aquaculture. 1993; 24: 68-73.

68. Fernández B. Evaluación de respuestas bioquímicas y anormalidades citogenotóxicas en mejillón silvestre (Mytilus galloprovincialis) como biomarcadores de contaminación ambiental [tesis]. (Dr.C): Universidad de Murcia; 2012.

69. Narváez N, Lodeiros C, Nusetti O, Lemus M, Maeda AN. Incorporación, depuración y efectos del cadmio en el mejillón verde Perna viridis (L. 1758) (Mollusca: Bivalvia). Ciencias Marinas. 2005 mar; 31(001A): 91-102.

70. Lemus M, Marín L, Aponte A, Chung K. Metalotioninas, glutation y consumo de oxígeno en el bivalvo Perna viridis expuesto a cadmio. Revista Científica, FCV-LUZ. 2012; XXII (4): 376- 382.

71. Medgar MJ. Desafío a la contaminación medio ambiental hídrica mediante la ecotoxicología y la ética. Discurso de ingreso como Académico correspondiente. Academia de Farmacia de Galicia; 2011 may 25; Galicia, España.

72. Centeno S, Rodríguez R. Actividad enzimática de bacterias frecuentes en camarones (Litopenaeus schmitti), mejillones (Perna viridis) y calamares (Loligo plei) congelados producidos en Cumaná, Estado Sucre, Venezuela. Rev. Soc. Ven. Microbiol. 2007; 27(1).

73. Pescados, Mariscos y sus Productos; (S/F). [Monografía en Internet]. [; citado 2012 dic 4]. Disponible en: http://www.itescam.edu.mx\%2Fprincipal\%2Fsylabus\%2Ffpdb\%2Frecursos\%2Fr23829.DO C\&ei=ZPi9UO7XDZOo8QSI_4GABA\&usg=AFQjCNEWUH8WWRAoLk2Ha KuCVCa6IAkg

74. Martínez RE, Villalobos de Bastardo LB. Escherichia coli enteropatógena en productos crudos y cocidos. Revista Científica, FCV-LUZ. 2005; XV (2): 163-167.

75. Muñoz D, Graü de Marín C, Villalobos de Bastardo LB, Martínez C, Zerpa A. Indicadores bacterianos en los mejillones Perna perna (Linné, 1758) y P. viridis (Linné, 
1758) y en las aguas de extracción de bivalvos procedentes de la costa norte y sur del estado Sucre, Venezuela. Revista Científica, FCV-LUZ. 2008; XVIII (5): 595-606.

76. Muñoz D, Graü de Marín C, Villalobos de Bastardo LB, Marjal H, Martínez C. Uso de Clostridium perfringens como indicador de contaminación fecal en zonas de cultivo de moluscos bivalvos en el estado Sucre, Venezuela. Revista Científica, FCV-LUZ. 2010; XX (6): $575-583$.

77. Graü de Marín C, La Barbera A, Zerpa A, Simón S, Gallardo O. Aislamiento de Vibrio spp. y evaluación de la condición sanitaria de los moluscos bivalvos Arca zebra y Perna perna procedentes de la costa nororiental del Edo. Sucre. Venezuela. Revista Científica, FCV. 2004; XIV (006).

78. Figueras A. Moluscos. Virus. Hepatitis y diarrea. [Monografía en Internet]; 2007 [citado 2012 nov 30]. Disponible en: http://www.madrimasd.org/blogs/ciencia_marina/2008/09/12/100774

79. Valle P, Lucas B. Toxicología de Alimentos. Instituto Nacional de Salud Pública. Centro Nacional de Salud Ambiental. México, DF. 2000.

80. Olavarría YA. Determinación de trazas de cadmio en cholga (Aulacomya ater), chorito (Mytilus chilensis) y ostra chilena (Ostrae chilensis) en la zona de Chiloé (Hueihue) [tesis]. (MI): Universidad Austral de Chile; 2007.

81. Iniesta R, Blanco J. Bioacumulación de hidrocarburos y metales asociados a vertidos accidentales en especies de interés comercial de Galicia. Revista Galega dos Recursos Mariños. 2005; Monografía: 2, 200p.

82. Lemus M. Perna viridis (Linné, 1785) como organismo centinela para evaluar contaminación ambiental en la costa oriental de Venezuela. The Biologist (Lima). 2009 jun-dic; 7 (1-2).

83. Ortega JA, Ferrís J, Cánovas A, García J. Neurotóxicos medioambientales. Metales: efectos adversos en el sistema nervioso fetal y postnatal. Acta Pediatr Esp. 2005; 63: 182192.

84. CODEX Alimentarius Commission. Joint FAO/WHO, Food Standards Programme. Codex Committee on Food Additives and Contaminants. CX/FAC 06/38/37. The Hague, Netherlands, 24 - 28 April 2006.

85. Reglamento (UE) No 420/2011 de la comisión 29 de abril de 2011 que modifica el Reglamento (CE) No 1881/2006, por el que se fija el contenido máximo de determinados contaminantes en los productos alimenticios. Diario Oficial de la Comunidad Europea. 2011; L 111/3.

86. NC 493:2012. Contaminantes metálicos en alimentos. Regulaciones sanitarias.

87. Durán IL, Fuentes MV, Gómez JA. Concentración de cadmio, plomo y cobre en Anadara tuberculosa del manglar de la Isla Taborcillo, Punta Chame, República de Panamá. Tecnociencia. 2004; 6(2): 91-104. 
88. Comisión del CODEX. Programa conjunto FAO/OMS sobre normas alimentarias. Comité del CODEX sobre contaminantes de los alimentos. Documento de trabajo con información y para los debates sobre los contaminantes y las toxinas en la NGCTA. CX/CF. Beijing, China, 16-20 de abril 2007.

89. Valdés F, Cabrera V. La contaminación por metales pesados en Torreón, Coahuila, México. [Libro en Internet]; Sept 1999. [Citado 2012 nov 23]. Disponible en: http://www.texascenter.org/tcps/btep/breports.htm

90. Poma A. Intoxicación por plomo en humanos. An Fac med. 2008; 69(2): 120-6.

91. Torres D. Los beneficios del cobre en la salud humana. [entrevista] realizada a: Uauy R. Director del Instituto de Nutrición y Tecnología de los Alimentos de la Universidad de Chile. 2004.

92. Rubio, C. Ingesta dietética de contaminantes metálicos $(\mathrm{Hg}, \mathrm{Pb}, \mathrm{Cd}, \mathrm{Fe}, \mathrm{Cu}, \mathrm{Zn}$ y $\mathrm{Mn}$ ) en la Comunidad Autónoma de Canaria. Evaluación toxicológica [tesis]. Modalidad Investigación (MI).Universidad de la Laguna; S/F.

93. Del Mar BM, A Polar, Luis Carnelli. Alcohol, Anemia sideroblástica y Hemosiderosis. Revista de la Sociedad de Medicina Interna de Buenos Aires. [monografía en Internet]; S/F. [Citado 2012 dic 10]. Disponible en: http://www.smiba.org.ar/med interna/vol 02/07 06.htm

94. Fletcher LM, Powell LW. Hemochromatosis and alcoholic liver disease. Alcohol. 2003 Jun; 30(2): 131-6.

95. Lostra J, Díaz P, García E. Hemocromatosis: hallazgos en resonancia magnética. Servicio de Diagnóstico por Imágenes Hospital Privado de Comunidad. Córdoba Mar del Plata. [monografía en Internet]; S/F. [Citado 2012 dic 10]. Disponible en: http://www.hpc.org.ar/images/revista/204-v4p63.pdf

96. Tango. Hemocromatosis. 2012 [Citado 2012 dic 10]. Disponible en: http://www.nlm.nih.gov/medlineplus/spanish/ency/article/000327.htm

97. Ziegler EE, Filer LJ. Conocimientos Actuales sobre Nutrición. 7ma ed. Oficina Panamericana de la Salud. Publicación Científica 565; 1997. p. 328-341.

98. Mendoza F. Determinación de metales pesados, $\mathrm{Cd}, \mathrm{Cr}, \mathrm{Cu}$ y $\mathrm{Pb}$ en Farfantepenaeus aztecas (Ives, 1891) colectados en la laguna de Tampamachoco, Veracruz [tesis]. Modalidad Investigación. Universidad Veracruzana; 2010.

99. Olivares M, Castillo C, Arredondo M, Uauy R, Dagach-Imbarack. Cobre y zinc en nutrición humana. [Capitulo de un libro en Internet]; S/F. [Citado 2012 dic 10]. Disponible en: http://www.uco.es/master nutricion/nb/Gil\%20Hernandez/Cu\%20Zn.pdf

100. Tanabe S. Fate of toxic chemicals in the tropics. Marine Pollution Bulletin.1991; 22: 259-260. (UNEP. Stockholm Convention on Persistent Organic Pollutants (POPs). Text and annexes. Geneva, Switzerland; 2011-64. Available from: www.unep.org 
101. García F. Tema 11: Compuestos Orgánicos Tóxicos; S/F. [Citado 2012 dic 12]. Disponible en: http://www.ugr.es/ fgarciac/pdf color/tema11\%20\%5BModo\%20de\%20compatibilidad\%5 D.pdf

102. Fundación vasca para la seguridad Agroalimentaria, Elika. Contaminantes orgánicos persistentes. berezi@18; S/F. [Citado 2012 dic 12]. Disponible en: http://www.elika.net/es/articulos.asp?id=914\#914

103. Convenio de Estocolmo sobre contaminantes orgánicos persistentes (COP) Texto y Anexos. Ginebra/Nairobi; 2001 (enmendado 2009). [Citado 2012 dic 1]. Disponible en: http://chm.pops.int/Portals/0/download.aspx?d=UNEP-POPS-COP-CONVTEXT.Sp.pdf

104. Isobe T, Takada H, Kanai M, Tsutsumi S, Isobe KO, Boonyatumanond $\mathrm{R}$ et al. Distribution of Polycyclic Aromatic Hydrocarbons (PAHs) and phenolic endocrine disrupting chemicals in South and Southeast Asian mussels. [serial on the Internet]. S/F. [Cited 2012 dic 10]: [about 18p.]. Available from: http://www.aseanenvironment.info/Abstract/43005661.pdf

105. Fundación vasca para la seguridad Agroalimentaria, Elika. Hidrocarburos aromáticos policíclicos en alimentos. berezi@especial009; S/F. [Citado 2012 dic 12]. Disponible en: http://www.elika.net/datos/articulos/Archivo697/Berezi\%20HAPs_ekaina11.pdf

106. EFSA Journal. 2008; (724): 1-114.

107. Reglamento (UE) $N^{o} 835 / 2011$ de la comisión de 19 de agosto de 2011 que modifica el Reglamento (CE) no 1881/2006 por lo que respecta al contenido máximo de hidrocarburos aromáticos policíclicos en los productos alimenticios. Diario Oficial de la Unión Europea. 2011; L 215/4.

108. Mirsadeghi SA, Zakaria MP, Yap CK, Shahbazi A. Risk assessment for the daily intake of polycyclic aromatic hydrocarbons from the ingestion of cockle (Anadara granosa) and exposure to contaminated water and sediments along the west coast of Peninsular, Malaysia. Journal of Environmental Sciences. 2011; 23(2): 336-345.

109. Resolución No. 538/12. Ministerio de la Industria Alimentaria. La Habana: 2 de agosto de 2012.

110. Ramírez JA, Lacasaña M. Plaguicidas: clasificación, uso, toxicología y medición de la exposición. Arch Prev Riesgos Labor. 2001; 4(2): 67-75.

111. Toxicología III. [Monografía en Internet]; S/F. [Citado 2012 dic 10]. Disponible en: http://www.bvsde.ops-oms.org/bvsacd/eco/033965/033965-02-b.pdf

112. Acción de los plaguicidas sobre el hombre y el medio. [Monografía en Internet]; S/F. [Citado 2012 dic 10]. Disponible en: http://aguas.igme.es/igme/publica/libro28/pdf/lib28/2_accion.pdf 
113. Peláez S. Pesticidas y cáncer vesical: aspectos epidemiológicos y anatomopatológicos [tesis]. Modalidad Investigación (MI).Universidad de Málaga; 1998.

114. Palacio DE. El registro de plaguicidas en Cuba. [Conferencia en Internet]; S/F. [Citado 2012 dic 15]. Disponible en: http://www.bvsde.opsoms.org/bvstox/tallerplagui/Cuba.pdf

115. Rimblas ME. Los compuestos químicos en los alimentos desde la perspectiva de la seguridad alimentaria. Murcia (Consejería de Sanidad): Imprenta Regional; 2004.

116. REGLAMENTO (UE) No 1259/2011 de la comisión de 2 de diciembre de 2011 por el que se modifica el Reglamento (CE) no 1881/2006 en lo relativo a los contenidos máximos de dioxinas, PCB similares a las dioxinas y PCB no similares a las dioxinas en los productos alimenticios. Diario Oficial de la Unión Europea. 2011; L 320/18.

117. Tomzack M, García C. A numerical model of circulation in Cienfuegos Bay, Cuba, Estuarine Coast. Mar. Sci. 1975; 3(4): 391-412.

118. Tur AI, Becerra M. Evaluación de las principales cargas de contaminantes de origen urbano-industrial vertidas directamente en la Bahía de Cienfuegos. Revista Científico-Técnica. I.T. 1991; 11(3): 8-10.

119. Seisdedo M, Muñoz A. Efecto de las precipitaciones en la calidad de las aguas de la Bahía de Cienfuegos. Rev. Cubana de Meteorología. 2005; 12(2): 64-67.

120. Seisdedo M. Variaciones espaciales y temporales en indicadores de la calidad ambiental de las aguas de la Bahía de Cienfuegos, Cuba. Rev. Invest. Mar. 2006; 21(2): 159-164.

121. Environmental Protection Agency; Office of Water 4304, in U.S. Nutrient Criteria Technical Guidance Manual. Estuarine and Coastal Marine Waters. EPA-822-B-01-003; 2001 .

122. National Science and Technology Council Committee on Environment and Natural Resources, Committee on Environmental and natural Resources. Integrated assessment of hypoxia in the northern Gulf of Mexico.Washington D.C; 2000.

123. Kennish MJ. Environmental threats and environmental future of estuaries. Environmental Conservation. 2002; 29: 78-107.

124. Rabalais N. Nitrogen in aquatic ecosystems. Ambio. 2002; 31: 102-112.

125. Beman JM, Arrigo KR, Matson PA. Agricultural runoff fuels large phytoplankton blooms in vulnerable areas of the ocean. Nature. 2005; 434: 211.

126. Cornelissen G, Rigterink H, Hulscher D, Vrind B, Noort P. A simple Tenax ${ }^{\circledR}$ extraction method to determine the availability of sediment-sorbed organic compounds. Environmental Toxicology and Chemistry. 2001; 20(4): 706-711. 
127. DelValls T. Chemical and ecotoxicological guidelines for managing disposal of dredged material. Trends in Analytical Chemistry. 2004; 23(10/11): 819-828.

128. Sprovieri M. Heavy metals, polycyclic aromatic hydrocarbons and polychlorinated biphenyls in surface sediments of the Naples harbour (southern Italy). Chemosphere, 2007; 67: 998-1009.

129. Casado MC, Forja JM, DelValls T. Direct comparison of amphipod sensitivities to dredge sediments from Spain ports. Chemosphere. 2007; 68: 677-685.

130. Ruiz, F. Proyecto "Evaluación y control de la contaminación marina en la Bahía de Guantánamo. Informe final. CIMAB.2001.

131. Tur A, Regadera R. Proyecto "Evaluación y control de la contaminación marina en la Bahía de Matanzas y la Zona Varadero-Cárdenas”. Informe final. CIMAB.2001.

132. Pérez M. Proyecto "Evaluación y control de la contaminación marina en la Bahía de Cienfuegos”. Informe final. CIMAB.2004.

133. García E. Proyecto "Evaluación y control de la contaminación marina en la Bahía de Puerto. Informe final. CIMAB.2004.

134. Castellanos ME, León AR, Moreira A, Miranda CE, Morales M. Integrando la información científica al proceso de toma de decisiones del MIZC: la bioindicación de los metales pesados a partir de las microalgas. Cub@: Medio ambiente y Desarrollo. 2008; $8(15)$.

135. Castellanos ME, Sosa L, Moreira A, León AR. Variación espacial y temporal de la bioconcentración de arsénico en macroalgas de la Bahía de Cienfuegos, Cuba. Rev. Invest. Mar. 2008; 29(3): 197-203.

136. García O. Proyecto "Control de la calidad ambiental del ecosistema marino Bahía de Cienfuegos”. Informe de proyecto. CIMAB. 2007.

137. Ruiz F, Pérez M, Beltrán J, Mancebo H, Regadera R, Martín A y col. Rev. Invest. Mar. 2008; 29 (1): 13-22.

138. Pérez O, Ruiz F, Torres I, Beltrán J. Contaminación por hidrocarburos en la Bahía de Guantánamo, Cuba. Rev. Invest. Mar. 2008; 29(2): 179-186.

139. AOAC 950.46/00. Moisture in meat. Official Methods of Analysis, 2000.

140. AOAC 940.25/00. Nitrogen (Total) in Seafood. Official Methods of Analysis, 2000

141. AOAC 955.04/00. Nitrogen (Total) in Fertilizers. Official Methods of Analysis, 2000.

142. AOAC 920.39/00. Official Methods of Analysis, 2000.

143. AOAC 938.08/00. Ash of Seafood. Official Methods of Analysis, 2000. 
144. NC ISO 6887-1: 2003. Microbiología de Alimentos de Consumo Humano y Animal- Preparación de la Muestra de Ensayo, la Suspensión Inicial y las Diluciones Decimales para Pruebas Microbiológicas.

145. ISO/TS 21872-1: 2007. Detection of potentially enteropathogenic Vibrio spp. - Part 1: Detection of Vibrio parahaemolyticus and Vibrio cholerae.

146. NC ISO 4833: 2011. Microbiología de alimentos de consumo humano y animal. Guía general para la enumeración de microorganismos. Técnica de conteo de colonias a 30 ${ }^{\circ} \mathrm{C}$. Método de Referencia (ISO 4833: 2003, IDT).

147. NC 38-02-14: 1989. Determinaciones cuantitativas de coliformes fecales. Métodos de ensayos microbiológicos.

148. NC ISO 7251: 2011. Microbiología de alimentos de consumo humano y animal. Método Horizontal para la detección y enumeración de Escherichia coli presuntiva. Técnica de número más probable. (ISO 7251: 2005, IDT).

149. NC ISO 6888-1: 2003. Microbiología de alimentos de consumo humano y animal. Método horizontal para la enumeración de Staphylococcus coagulasa positiva (Staphylococcus aureus y otras especies). Parte 1: Técnica utilizando el medio Agar Baird Parker (ISO 6888-1: 1999, IDT).

150. NC ISO 6579: 2008. Microbiología de Alimentos de Consumo Humano y AnimalMétodo Horizontal para la Detección de Salmonella spp.

151. IA 6746: 10,1999. Materiales Biológicos. Determinación de $\mathrm{Cu}, \mathrm{Zn}, \mathrm{Cd}$ y $\mathrm{Pb}$. Voltametría de Redisolución Anódica.

152. IA 6746: 11, 1999. Suelos. Determinación de Al, Ca, Cr, Mn, Fe, Ni, Cu, Zn y Pb. Espectrofotometría de Absorción Atómica.

153. IA 6746: 19. Materiales biológicos. Determinación del contenido de $\mathrm{Hg}$ en muestras de pescado y mariscos mediante Vapor Frio. Espectrofotometría de Absorción Atómica previa digestión ácida en horno de microondas.

154. ( ${ }^{\text {EPA } 8100: 1990}$ ) EPA 8100: 1990. Determination of polycyclic aromatic compounds for Chromatography.

155. Dirección Productiva Pesquera, Grupo de Industria. Actualización de los Indicadores de eficiencia industrial de las producciones pesqueras del Grupo Empresarial de la Industria Alimentaria. GI-66/2012.GEIA, La Habana 26 de abril 2012.

156. Veras VM, Bessa CE. Contribuicao para o conhecimiento da viabilidad do cultivo de ostra-do-mangue, Crassotrea rhizophorae, no estuario do rio Ceara, Brasil. 1988

157. Acosta V, Prieto A, Licett B, Longart Y, Montes M. Rendimiento, índice de condición y esfuerzo reproductivo del mejillón verde Perna viridis en cultivo de fondo en el Golfo de Cariaco, estado Sucre, Venezuela. Zootecnia Trop. 2011; 29(4): 399-410. 
158. Ramos M, Cabello A. Elaboración y evaluación de una pasta para untar a base de mejillón (Perna perna). Resúmenes del I Congreso Venezolano de Ciencias Acuáticas, Universidad de Oriente. 17 y 22 de octubre. 1994. 41p.

159. Benitez J, Okuda T. Variación estacional en la composición química del mejillón Perna perna (L) natural. Bol. Inst. Oceanog. Univ. Oriente. 1971; 10(1): 3-8.

160. Lauro A. Estudio de conservación por congelación del mejillón Perna perna desintegrado. Universidad Central de Venezuela. Caracas, Venezuela (Tesis de Pregrado). 1980.

161. Pis, M. y Pérez, O. Composición química estacional del ostión Crassostrea rhizophorae cultivado al norte de Matanzas, Cuba. Revista Industria Cárnica Latinoamericana. 2009; 157.

162. Márquez FY, Cabello MA, Villalobos LB, Gracia G, García FB, González V. Cambios físicos-químicos y microbiológicos observados durante el proceso tecnológico de la conserva de atún. Zootecnia Tropical. 2005; 24(1): 17-29.

163. Kodaira M. Composición química y cambios post-morten en pescado, crustáceos y moluscos. Curso-Taller "Avances en biotecnología de organismos marinos de importancia comercial" Universidad Central de Venezuela. Universidad de Oriente. Isla de Margarita. 1991; $31 \mathrm{p}$.

164. Hernández M, Porrata C, Jiménez S, Rodríguez A, Carrillo O, García A. Recomendaciones nutricionales para la población cubana. La Habana: Cámara del Libro; 2009.

165. NC 585: 2011. Contaminantes microbiológicos en alimentos — requisitos sanitarios.

166. Directiva 2006/113/CE del Parlamento Europeo y del consejo 12/12/2006 sobre la calidad requerida para las aguas para la cría. 2006; DO L 376/14.

167. Reglamento (CE) 2073/2005 de la comisión del 15/11/2005 relativo a los criterios microbiológicos aplicables a los productos alimenticios. 2005; DO L 338.

168. Llop A, Valdés-Dapena M, Zuazo JL. Microbiología y Parasitología Médicas. Tomo I. 1 ed. Editorial Ciencias Médicas; 2001. p. 266-76.

169. Ramos-Ortega LM, Vidal LA, Vilardy S, Saavedra-Díaz L. Análisis de la contaminación microbiológica (coliformes totales y fecales) en la Bahía de Santa Marta, Caribe Colombiano. Acta biol.Colomb. 2008; 13(3): 87-98.

170. Berenice L. Tipos de cultivo y usos comerciales de moluscos en el estado Sucre. INIA Hoy. 2009 Enero-Abril; (4): 103-7.

171. González M, Villalobos LB, Vásquez-Suarez A, Grau C, Gil H. Enumeración de aerobios mesófilos, coliformes fecales y Clostridium prefringens en la ostra Crasostrea 
rhizophorae procedente de la laguna grande del obispo, estado de Sucre, Venezuela. Revista Científica, FCV-LUZ. 2011; 21(1): 80-87.

172. Food and Drug Administration (F.D.A.). Sanitation of shellfish growing areas. National shellfish sanitation program. Manual of operations. Part. 1. U.S. Dep. of Health and Human Services. Public Health Service. Washington, D.C.; 1990. p. 550.

173. Leiva V, Martino TK, Puig Y. Factores que influyen en el crecimiento y supervivencia de los microorganismos. En: Caballero AE. Temas de Higiene de los Alimentos. La Habana: Editorial Ciencias Médicas; 2008. p. 43-54.

174. Leyva V, Martino TK, Puig Y, Carrera J, Cabrera MR. ¿Qué factores influyen en el crecimiento y supervivencia de los microorganismos en los alimentos? [Monografía en Internet]; S/F. [Citado 2012 dic 16]. Disponible en: http://www.inha.sld.cu/doc pdf/crecimiento.pdf

175. Dirección Control Productivo. Grupo Empresarial Industria Alimentaria. Informe Programa Pesquero. Consejo productivo. 28 nov 2008.

176. Usero J, González E, García I.. Trace metals in the bivalve mollusk Chamelea gallina from the Atlantic coast of southern Spain. Mar. Pollut. Bull. 1996; 32(3): 305-310.

177. Acosta V, Lodeiros C. Metales pesados en la almeja Tivela mactroides Born, 1778 (Bivalvia: Veneridae) en localidades costeras con diferentes grados de contaminación en Venezuela. Ciencias Marinas.2004; 30: 323-333.

178. Mubiana V, Blust R. Effects of temperature on scope for growth and accumulation of $\mathrm{Cd}, \mathrm{Co}, \mathrm{Cu}$ and $\mathrm{Pb}$ by the marine bivalve Mytilus edulis. Marine Environmental Research. 2007; 63: 219-235.

179. Rajkumar W, Mungal R, Bahadoorsingh E. Heavy metal concentration in sea water, sediment, and biota (Donax striatus) along the east coast of Trinidad. Carib. Mar. Stud. 1992; 3: 26-32.

180. Laksmanan P, Nambisan P. Seasonal variations in trace metal content in bivalve mollusks. 1983; 12: 100-103.

181. Salazar C. Variación temporal de metales pesados esenciales y no esenciales en el isópodo litoral Tylos wegeneri (Vandel, 1952) en Guayacán, estado Sucre, Venezuela. Trabajo especial de Grado, Universidad de Oriente, Departamento de Biología, Cumaná. 2011; 26 p.

182. Aatmeeyata MS. Aromatic hydrocarbons, elemental and organic carbon emissions from tire-wear. Science of the total environmental. 2010; 408(20): 4563-68.

183. Fernandez P, Vilanova RM, Grimalt JO. Sediment fluxes of polycyclic aromatic hydrocarbons in European high altitude mountain lakes. Environ. Sci. Technol. 1999; 33(21): 3716-3722. 
184. Soriano JA. Datos preliminares de HAPs en mejillón silvestre de la costa Cantábrica (España) después del vertido del Prestige. Ciencias Marinas. 2006; 32(2B): 457-63.

185. (NOM 2009) Norma Oficial Mexicana. Productos y servicios. Productos de la pesca frescos, refrigerados, congelados y procesados. Especificaciones sanitarias y métodos de prueba. Diario Oficial de la federación. 2009; 242-SSA1.

186. Richardson BJ, Zheng GJ, Tse E, Lam P. A comparison of mussels (Perna viridis) and semi-permeable membrane devices (SPMDs) for monitoring chlorinated trace organic contaminants in Hong Kong coastal waters. Chemosphere. 2001; 45: 1201-1208.

187. García AJ. Riesgos químicos en productos de la pesca. Universidad de Murcia. [Monografía en Internet]; 28 marz 2009. [Citado 2012 dic 10]. Disponible en: http://digitum.um.es/xmlui/bitstream/10201/16294/1/Riesgos\%20quimicos\%20en\%20pesca . $\mathrm{pdf}$

188. Shuhong W, Huasheng H, Xinhong W. Bioenergetic responses in green lipped mussels (Perna viridis) as indicators of pollution stress in Xiamen coastal waters, China. Marine Pollution Bulletin. 2005; 51: 738-743.

189. Namiesnik J, Moncheva S, Park YS, Ham KS, Heo BG, Tashma Z.Concentration of bioactive compounds in mussels Mytilus galloprovincialis as an indicator of pollution. Chemosphere. 2008; 73: 938-944.

190. Páez F, Osuna C. Biomonitores de la contaminación costera con referencia a las costas mexicanas: una revisión sobre los organismos utilizados. Hidrobiológica. 2011; 21(3): 229-238.

191. Asociación para la Defensa de los Recursos Naturales de Cantabria (ARCA). Dioxinas y Furanos. [Monografía en Internet]; 1 Ene 2004. [Citado 2012 dic 10]. Disponible en: http://www.iarca.net/pdf/dioxinasyfuranos.pdf

192. Potrykus J, Albalat A, Pempkowiak J, Porte C. Content and pattern of organic pollutants (PAHs, PCBs and DDT) in blue mussels (Mytilus trossulus) from the southern Baltic Sea. Oceanología. 2003; 45(1): 337-355. 